\title{
LUCIANA CORRÊA
}

ANÁLISE DA MUDANÇA DE PARADIGMA DO ENSINO DE GRADUAÇÃO EM PATOLOGIA NA ODONTOLOGIA:

PROPOSTA DE ENSINO-APRENDIZADO

A DISTÂNCIA VIA INTERNET

Área de Concentração: Patologia Bucal 


\author{
UNIVERSIDADE DE SÃO PAULO \\ FACULDADE DE ODONTOLOGIA
}

\title{
ANÁLISE DA MUDANÇA DE PARADIGMA DO ENSINO DE GRADUAÇÃO EM PATOLOGIA NA ODONTOLOGIA: \\ PROPOSTA DE ENSINO-APRENDIZADO \\ A DISTÂNCIA VIA INTERNET
}

\section{LUCIANA CORRÊA}

Tese apresentada à Faculdade de Odontologia da Universidade de São Paulo, para obter o Título de

Doutor, pelo programa de Pós-Graduação em Odontologia - Área de concentração em Patologia Bucal.

São Paulo 
UNIVERSIDADE DE SÃO PAULO

FACULDADE DE ODONTOLOGIA

\section{ANÁLISE DA MUDANÇA DE PARADIGMA DO ENSINO DE GRADUAÇÃO EM PATOLOGIA NA ODONTOLOGIA: \\ PROPOSTA DE ENSINO-APRENDIZADO \\ A DISTÂNCIA VIA INTERNET}

\section{LUCIANA CORRÊA}

Tese apresentada à Faculdade de Odontologia da Universidade de São Paulo, para obter o Título de

Doutor, pelo programa de Pós-Graduação em Odontologia - Área de concentração em Patologia Bucal.

Orientadora:

Profa. Dra. Suzana Cantanhede Orsini Machado de Sousa

São Paulo 
Data da Defesa:

\section{BANCA EXAMINADORA}

Prof. Dr.

Julgamento:

Assinatura:

Prof. Dr.

Julgamento: Assinatura:

Prof. Dr.

Julgamento: Assinatura:

Prof. Dr.

Julgamento: Assinatura:

Prof. Dr.

Julgamento: Assinatura: 


\title{
DEDICATÓRIA
}

\author{
Aos alunos de graduação \\ da Faculdade de Odontologia da \\ Universidade de São Paulo
}




\section{SUMÁRIO}

RESUMO

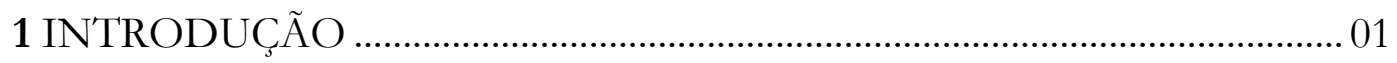

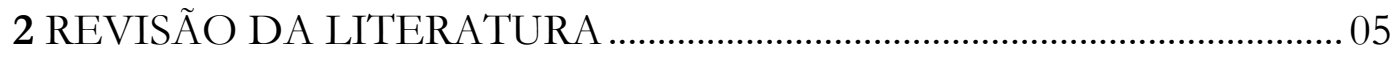

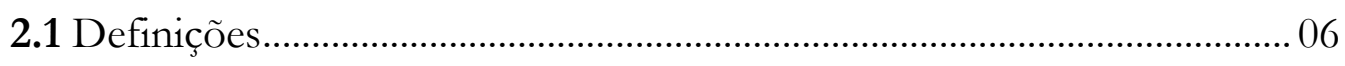

2.2 Produção de material didático para a Internet............................................. 10

2.3 Contexto envolvendo a implantação de cursos via Internet e programas

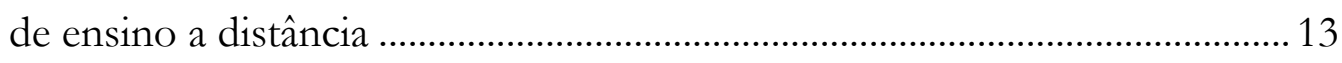

2.4 "Sites" na Internet de escolas de Odontologia com material didático

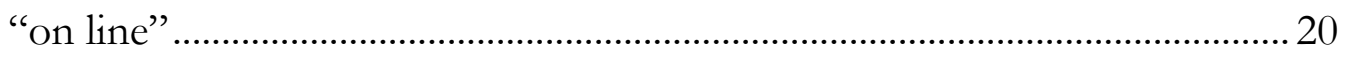

2.4.1 Escolas de Odontologia norte-americanas .................................................22

2.4.2 Escolas de Odontologia escandinavas, japonesas, européias e australianas

2.4.3 Escolas de Odontologia latino-americanas .

2.5 Alguns dados obtidos a partir de cursos "on line”na área médica .......... 30

2.6 Questões gerais sobre educação utilizando computador .....

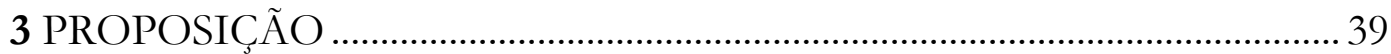

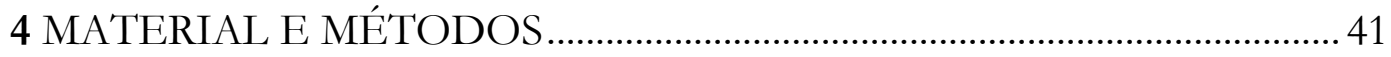

4.1 Análise da relação do aluno de graduação com o computador e a Internet.

4.2 Criação de banco de dados digitais 


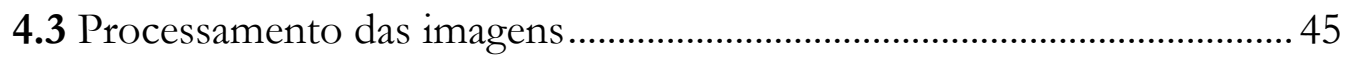

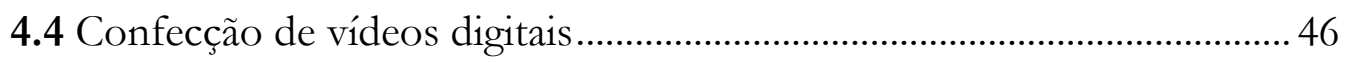

4.5 Criação dos "sites"............................................................................................. 46

4.6 Teste dos “sites” e avaliação .......................................................................... 51

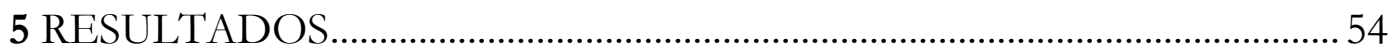

5.1 Dados obtidos a partir do questionário A.1 (Anexo A) ............................ 55

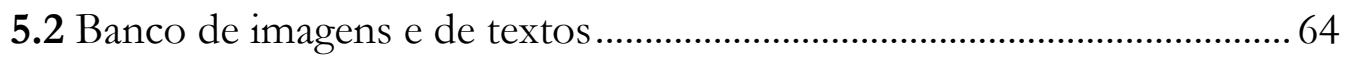

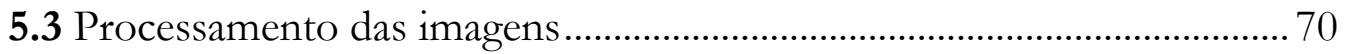

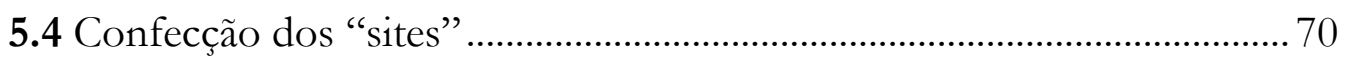

5.5 Teste dos "sites” e avaliação ........................................................................... 75

5.6 Protocolo preliminar de confecção de material didático "on line”

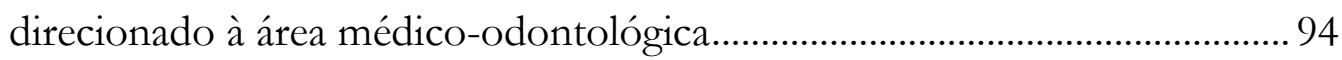

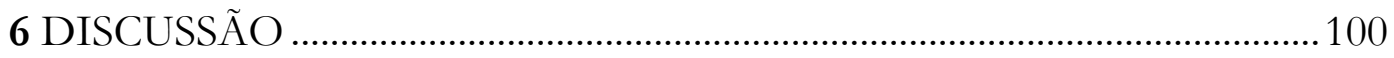

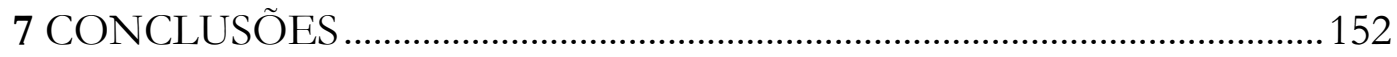

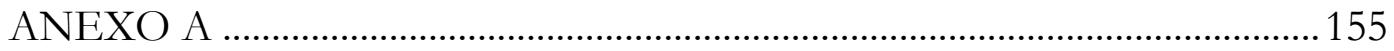

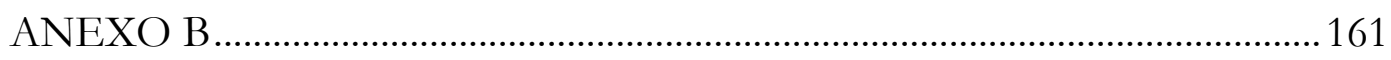

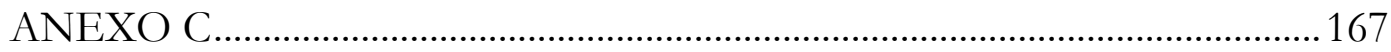

REFERÊNCIAS .................................................................................... 177

SUMMARY

APÊNDICE 


\section{LISTA DE GRÁFICOS E FIGURAS}

GRÁFICO 5.1 - Distribuição dos sexos masculino e feminino nos cursos diurno (67 alunos) e noturno (47 alunos)

GRÁFICO 5.2 - Distribuição quanto à faixa etária dos alunos do curso diurno (67 alunos) e noturno (47 alunos) 56

GRÁFICO 5.3 - Porcentagem de alunos que possuem ("sim) e não possuem (“'não) computador em casa, tanto do curso diurno (67 alunos) quanto do curso noturno (47 alunos)

GRÁFICO 5.4 - Distribuição (em porcentagem) dos alunos do curso diurno (67 alunos) e do curso noturno (47 alunos) quanto à quantidade de aplicativos conhecidos

GRÁFICO 5.5 - Distribuição (em porcentagem) dos alunos do curso diurno (67 alunos) e do curso noturno (47 alunos) quanto aos aplicativos conhecidos. 58

GRÁFICO 5.6 - Distribuição (em porcentagem) dos alunos que acessam e dos que não acessam a Internet, tanto do curso diurno (67 alunos) quanto do curso noturno (47 alunos)

GRÁFICO 5.7 - Motivos que levam os alunos a não acessar a Internet (freqüência em porcentagem), tanto do curso diurno (67 alunos) quanto do curso noturno (47 alunos).

GRÁFICO 5.8 - Distribuição (em porcentagem) da freqüência de acessos à Internet pelos alunos tanto do curso diurno (67 alunos) quanto do curso noturno (47 alunos)

GRÁFICO 5.9 - Distribuição (em porcentagem) das formas de utilização da Internet realizada pelos alunos tanto do curso diurno (67 alunos) quanto do curso noturno (47 alunos) 
GRÁFICO 5.10 - Distribuição (em porcentagem) da quantidade de formas de utilização da Internet apontadas pelos alunos tando do curso diurno (67 alunos) quanto do curso noturno (47 alunos)

GRÁFICO 5.11 - Distribuição (em porcentagem) dos tipos de sites consultados pelos alunos tanto do curso diurno (67 alunos) quanto do curso noturno (47 alunos)......

GRÁFICO 5.12 - Distribuição (em porcentagem) do número de alunos, tanto do curso diurno (67 alunos) quanto do curso noturno (47 alunos), que gostaria ou não de acessar as matérias de Odontologia pela Internet.

GRÁFICO 5.13 - Distribuição (em número absoluto) quanto à idade dos estudantes do curso de introdução à técnica cirúrgica.

FIGURA 5.1 - "Site” da Patologia Bucal: A: Página de abertura. B: Exemplo de caso clínico com imagens radiográficas. C: Exemplo de como as imagens histológicas são apresentadas, podendo ser visualizadas em maior aumento e com descrições morfológicas detalhadas $(\mathbf{D})$. 72

FIGURA 5.2 -"Site" da Patologia Geral. A: Página de abertura do "site”. B: Exemplo de tópico desenvolvido; as palavras grifadas e em cor azul são “links"para outras páginas. C: Banco de imagens, o qual é composto por imagens clínicas, macroscópicas e histológicas. D: Exemplo de maior aumento das imagens contidas no banco, havendo uma descrição detalhada da figura . .73

FIGURA 5.3 - "Site” do Curso de introdução à técnica cirúrgica. A: Página de abertura do "site". B: Explicações sobre o material do curso. C: Base teórica, a qual remete para conceitos de cirurgia, patologia e anatomia. D: Última fase do curso, em que os alunos aprendem a suturar os diferentes planos teciduais.

FIGURA 5.4 - Exercícios de Patologia Bucal. A: Questão 1 referente ao exame histológico de lesões significativas para o aluno de graduação. B: Questão $2 \mathrm{em}$ que se relaciona dados de exames complementares diferentes sobre lesões do mesmo grupo classificatório .76

FIGURA 5.5 - Alunas de graduação no momento de confecção dos exercícios de Patologia Bucal. .77

FIGURA 5.6 - Exercícios de Patologia Geral. A: Personagens caricaturescos que se antagonizam e criam polêmicas envolvendo os processos patológicos 
gerais. B: O confronto entre uma situação clínica de origem sistêmica e uma de origem local específica da área odontológica fazem com que os alunos reflitam sobre a magnitude dos processos gerais

FIGURA 5.7 - Alunos acessando o "site" de Patologia Geral no Laboratório de Informática Dedicado à Odontologia. Estavam disponíveis nessa sala um PC e duas estações Silicon Graphics, as quais foram manipuladas pelos alunos sem constrangimento, mesmo sem conhecer essa plataforma

FIGURA 5.8 - Recursos tecnológicos disponíveis no dia do curso: circuito interno de televisão, o qual recebia imagens coletadas por microcâmeras de mesas de documento (B) focalizadas na área de trabalho do aluno, microcomputador contendo software de ensino a distância e centro controlador, à frente da sala, com ilha de edição, videocassete, microcomputador e microscópio, todos também conectados ao circuito interno de TV(A) 92

FIGURA 5.9 - A: Início do curso, em que os alunos se interam do "site" e consultam os fundamentos teóricos antes de iniciar os passos da técnica. A dupla em destaque encontra-se paramentada para dar início aos procedimentos cirúrgicos, diferentemente da dupla mais ao fundo. B: Aluna na segunda etapa do curso, aprendendo a dar anestesia. A página do "site" visualizada no monitor condiz com sua ação, ou seja, a aluna segue o "site" passo-a-passo para executar a técnica cirúrgica

FIGURA 5.10 - A: Aluna acessando o "site" durante o curso. Observe como seu braço e seu corpo encontram-se esticados, em posição anti-ergonômica. B: Duas páginas distintas nos monitores 1 e 2 (com conteúdo referente à mesma etapa da técnica cirúrgica, porém com passos diferentes), demonstrando como cada dupla incutiu seu ritmo pessoal 


\section{LISTA DE TABELAS}

TABELA 5.1 - Distribuição (em número absoluto) dos alunos participantes do curso de introdução à técnica cirúrgica nas diferentes instituições de ensino de Odontologia do País

TABELA 5.2 - Banco de casos clínicos estruturado para o "site" da Disciplina de Patologia Bucal: quantidade de casos e distribuição entre os grupos de patologias......

TABELA 5.3 - Natureza e quantidade de imagens digitalizadas do banco de imagens estruturado para o "site" da Patologia Bucal. .66

TABELA 5.4 - Quantidade de imagens digitalizadas que compõem o banco de imagens para cada um dos itens temáticos estruturado para o "site" da Patologia Geral.

TABELA 5.5 - Natureza e quantidade de imagens digitalizadas do banco de imagens estruturado para o "site" da Patologia Geral.

TABELA 5.6 - Principais componentes do "site" da Patologia Bucal (quantidade e tamanho dos arquivos em $\mathrm{kb}$ ).

TABELA 5.7 - Principais componentes do "site" da Patologia Geral (quantidade e tamanho dos arquivos em $\mathrm{kb}$ )

TABELA 5.8 - Principais componentes do "site" do curso de introdução à técnica cirúrgica (quantidade e tamanho dos arquivos em $\mathrm{kb}$ )

TABELA 5.9 - Quantidade de alunos em relação ao local de acesso ao "site" da

Patologia Bucal

TABELA 5.10 - Características das pessoas cadastradas no "site" da Patologia Bucal no período de julho de 2000 a janeiro de 2001 
TABELA 5.11 - Estado de origem dos usuários cadastrados no "site" da Patologia Bucal ...

TABELA 5.12 - Quantidade de alunos em relação ao local de acesso ao "site" da Patologia Geral. 


\section{LISTA DE ABREVIATURAS E SIGLAS}

ASP - Active Server Pages (servidor que cria dinamicamente páginas em HTML)

AVI - Audio Video Interleave (formato padrão de vídeo digital para Windows)

CD-ROM - Compact Disk Read Only Memory

CGI - Common Gateway Interface (interface construída a partir das linguagens C, Perl, Java ou Visual Basic, que possibilita a formação de páginas em HTML mais dinâmicas)

DPI - Dots Per Inch (unidade utilizada para indicar a resolução de uma imagem digital)

FOUSP - Faculdade de Odontologia da Universidade de São Paulo

GIF - Graphics Interchange Format (formato de imagem composta por mapa de bits)

HTML - HiperText Markup Language (linguagem utilizada para a confecção de hipertextos para Internet)

HTTP - HiperText Transfer Protocol (protocolo de transferência de hipertextos utilizado na Internet)

Internet - International Net (rede internacional de informações)

Intranet - rede interna a uma dada organização, protegida de acessos externos

JPEG - Joint Photograph Expert Group (formato de imagem com sistema de compressão)

$\mathbf{k b}$ - kilobytes

LIDO - Laboratório de Informática Dedicado à Odontologia (sediado na Disciplina de Patologia Geral da FOUSP)

$\mathbf{M b}$ - megabytes

MPEG -Moving Picture Experts Group (formato de vídeo digital com sistema de compressão)

PC - Personal Computer

PDF - Portable Document Format (formato de documento cujo acesso independente do aplicativo que o originou)

SIAE - Sistema Integrado de Apoio ao Ensino (programa criado pelas Pró-Reitorias de Graduação e Pós-Graduação da USP, para incentivar a inserção das novas tecnologias de informação no aprendizado)

SVHS - Super Video Home System (formato de vídeo analógico)

WEB - teia em inglês; metonímia de World Wide Web

WWW - World Wide Web (teia mundial de informações) 


\section{RESUMO}

\section{ANÁLISE DA MUDANÇA DE PARADIGMA DO ENSINO DE GRADUAÇÃO EM PATOLOGIA NA ODONTOLOGIA: PROPOSTA DE ENSINO-APRENDIZADO A DISTÂNCIA VIA INTERNET}

O ensino a distância é uma modalidade recente de ensino-aprendizado, envolvendo tecnologias modernas de informação, dentre elas a Internet. $\mathrm{Na}$ área médico-odontológica, o ensino a distância tem sido empregado principalmente para cursos de educação continuada e de pós-graduação, cujos resultados acerca da relação custo/benefício e de graus de eficiência ainda estão para serem delineados. Para a graduação, existem poucos relatos citados na literatura referentes à aplicação do ensino a distância juntamente com a Internet. O objetivo deste trabalho foi analisar o efeito que a mudança de paradigma de ensino acarretou sobre os alunos dos cursos diurno e noturno do primeiro semestre de 2000, ao se aplicarem "sites" de Patologia Geral e Patologia Bucal juntamente com o ensino presencial. Dentro dessa análise, priorizou-se a reflexão acerca do potencial interdisciplinar fornecido pela tecnologia dos hipertextos e seu efeito sobre o corpo discente e docente, bem como o estabelecimento de um protocolo de produção de material didático “on line”. Para tanto, foram criados 
bancos de dados digitais para as duas disciplinas, os quais serviram como fonte de informações para a estruturação de três "sites": um relacionado à Patologia Bucal e dois à Patologia Geral. Esses "sites" foram aplicados para os graduandos do primeiro semestre de 2000 que estavam cursando as disciplinas de Patologia Geral e Bucal, bem como para alunos de graduação de várias instituições de Odontologia do País, participantes do curso de introdução à técnica cirúrgica ministrado no XXV Congresso Universitário Brasileiro de Odontologia. Os resultados da aplicação dos "sites" indicaram que os alunos estão aptos a utilizar a Internet como ferramenta de estudo e aprovaram a iniciativa de implementação de um ensino misto (presencial e não-presencial); contudo, ainda mostram-se reticentes quanto ao estudo por intermédio de uma linguagem baseada em hipertexto, o que denota serem alunos ainda em transição quanto a essa nova modalidade de comunicação. Foram detectadas ainda falhas de infra-estrutura tecnológica na instituição, bem como um descompasso entre as aulas presenciais e não-presenciais. Concluiu-se que é viável a mudança de paradigma do ensino atual na Odontologia, considerando-se o preparo e a receptividade dos alunos para essa mudança; contudo, certas modificações por parte da instituição e do corpo docente deverão ser feitas, principalmente no que concerne à infraestrutura tecnológica, ao plano curricular e às estratégias pedagógicas que visam interdisciplinaridade. 


\section{INTRODUÇÃO}

A educação na área de Odontologia não tem sido foco de discussões e de projetos no Brasil. As publicações científicas envolvendo o tema são raras, assim como relatos de programas educacionais específicos. Em consulta informal pela base de dados da Literatura Latino-Americana e do Caribe em Ciências da Saúde (LILACS) e da Biblioteca Brasileira de Odontologia (BBO), desde 1986, foram publicados somente 146 trabalhos envolvidos com educação e seus subtemas (ensino, didática, aprendizado, projetos institucionais) na área médica, dos quais 36 eram da área de Odontologia.

Diante da escassez de produção científica em educação odontológica, os trabalhos envolvendo o uso da informática na educação não se configuram como representativos de uma linha de pesquisa atuante. $\mathrm{Na}$ base de dados Medline, em pesquisa informal, foram listados 4412 trabalhos científicos cruzando-se os termos "computador" e "educação" nos últimos cinco anos; com o cruzamento de "computador", "educação" e "Odontologia", foram listados 120 trabalhos. A maioria deles foi produzida nos EUA (48\%) e na Inglaterra (16\%); no Brasil, somente um trabalho foi listado, o de Fernandes et al. (1998).

A despeito de sua ausência na produção científica odontológica, o tema “educação", atualmente, tem sido mais abordado em outras áreas, devido ao desenvolvimento dos sistemas de redes digitais (como a Internet e Intranet). Os 
grandes centros de pesquisa destinados ao aprimoramento tecnológico têm explorado o chamado "ensino a distância", modalidade pedagógica na qual se aliam instrumentos de comunicação e formas de ensino-aprendizado entre duas pessoas espacialmente distantes (Santos \& Rodrigues, 1999), a exemplo dos cursos por correspondência. Esse recurso não é novo; já no século XVIII foi criado na Inglaterra o primeiro centro educacional de ensino de línguas a distância (Bonilha \& Caldas, 1999). Hoje, falar desse tema implica considerar, de forma indissociável, o papel do computador e das redes digitais de transmissão da informação.

Nesse contexto de ensino a distância, o qual inclui necessariamente a produção de material didático eletrônico, a Internet assume um destaque como meio pelo qual as informações são disponibilizadas e acessadas. Particularmente a linguagem HTML, veiculada pela Internet e destinada à produção de hipertextos, possui um mecanismo de acesso a informações que favorece, em muito, o autoaprendizado. Por ser um recurso que começou a se difundir no meio da década de 90, ainda há muito a ser discutido acerca de seu potencial pedagógico.

Os estudos envolvendo ensino a distância são poucos na literatura das três áreas do conhecimento (exatas, humanas e biológicas). Projetos educacionais completos que consideram o recurso como a base do sistema educacional estão sendo desenvolvidos praticamente somente nos Estados Unidos e na Inglaterra; a maioria das experiências com ensino a distância envolve disciplinas e departamentos isolados, constituindo ainda resultados que podem ser considerados preliminares dentro de uma proposta educacional. $\mathrm{Na}$ Odontologia, 
o ensino a distância tem merecido atenção de algumas universidades americanas, inglesas e australianas, também com poucos resultados disponíveis na literatura científica. Dentre esses trabalhos, encontram-se pesquisas envolvendo a produção de material didático e o papel da Internet no ensino de Odontologia, com um enfoque praticamente empírico do processo: cria-se o CDROM a partir da conversão de documentos analógicos para digitais, mas não se faz sua aplicação; disponibiliza-se na Internet o material produzido, mas não se testa seu grau de didática; enfim, os estudos são embrionários e ainda a serem explorados cientificamente.

Um dos pontos interessantes a se considerar nessas análises seria o potencial de interdisciplinaridade que esses meios possuem. No curso de graduação da FOUSP, as disciplinas de Patologia (Geral e Bucal) necessariamente fazem conexões a outras disciplinas, devido ao caráter extremamente interdisciplinar inerente ao seu raciocínio diagnóstico. Um exemplo disso é a Disciplina de Patologia Geral da FOUSP, que ministra um curso de introdução à técnica cirúrgica para os alunos de graduação com o objetivo de transmitir os processos patológicos gerais vinculados ao ato operatório. Este trabalho, assim, visou convergir esse potencial interdisciplinar para a estrutura da Internet, construindo-se três "sites": um relacionado à Disciplina de Patologia Bucal e outros dois relacionados à Disciplina de Patologia Geral. Demonstramos, a seguir, um dossiê sobre grande parte dos aspectos envolvidos com a mudança de paradigma do ensino e com o impacto dessa mudança sobre os alunos, os professores e a instituição. 


\section{REVISÃO DA LITERATURA}




\section{REVISÃO DA LITERATURA}

Dividimos a revisão da literatura em seis partes, na tentativa de abranger os múltiplos aspectos relacionados ao ensino a distância. A primeira parte destina-se a citar algumas definições básicas de certas terminologias constantemente utilizadas neste trabalho. A segunda parte contém alguns autores importantes ligados diretamente à sistemática de produção de páginas para a WEB. A forma como estão sendo buscados indicadores de produção de material “on line” está retratada na terceira parte. A quarta parte é composta por um levantamento dos "sites" de escolas de Odontologia do mundo todo que contêm material didático na Internet. Esse levantamento é seguido por uma breve descrição de alguns cursos a distância desenvolvidos na área médica, a qual compõe a quinta parte. Por fim, fechando a revista da literatura como sexto item, citamos algumas experiências feitas com o computador e estudantes do nível primário e secundário, bem como são apontados autores que refletem sobre o impacto das novas tecnologias na educação.

\section{1 Definições}

Os termos que serão mais empregados durante o desenvolvimento deste trabalho são Internet, WWW, “site”, "homepage”, hipertexto e ensino a distância. Cada um deles, atualmente, possui várias definições segundo a fonte pesquisada e a área de interesse. Nos artigos científicos odontológicos, as definições desses 
termos quase sempre estão ausentes; as encontradas foram inseridas neste trabalho. Outras fontes serviram como complementação para essas definições, procurando-se esclarecer a origem e o significado desses termos, mais do que se chegar a um consenso sobre eles.

Putten Jr. (1996) considera uma definição de Internet difícil, devido a sua universalidade e complexidade; opta, então, por uma descrição: rede mundial que interconecta computadores e redes de computadores, estruturada para suportar correio eletrônico, transferência de arquivos e outras interações baseadas no emprego computacional. $\mathrm{O}$ autor considera a Internet um meio que promove uma nova modalidade de educação, de produção científica e de transações comerciais. Segundo Leão (1999), a Internet nasceu em 1969 nos Estados Unidos, sendo denominada na época de ARPA (Advanced Research Projects Agency). Tinha por finalidade, em plena Guerra Fria, conectar diversos departamentos de defesa norte-americanos. Já naquela época, essa rede foi concebida para ter uma grande capacidade de autogênese, ou seja, se um dos pontos que conecta tiver algum problema a ponto de não poder mais participar das conexões, estas assumem outras trilhas de modo a não invalidar o sistema.

Já a $W$ orld Wide $W e b(W W W)$ surgiu na Suíça como um projeto acadêmico do Centro Europeu de Pesquisas de Partículas (Centre for European Particle Research - CERN) para integrar um grande número de computadores sob um mesmo protocolo de acesso (Putten Jr., 1996). Para a criação desse protocolo de acesso universal, estruturou-se o formato "http" (Hypertext Transfer Protocol), o 
qual é traduzido pelos programas de acesso a WWW, ou navegadores, como o Netscape ${ }^{\circledR}$ e o Internet Explorer ${ }^{\circledR}$.

Toda a arquitetura da WWW é composta por unidades mínimas denominadas "sites" ou pelas "homepages". "Site" é atualmente entendido como um ponto, um nó, das redes de comunicação; pode ser composto por somente uma página ou por várias páginas (Leão, 1999). Uma "homepage”, por sua vez, constitui a página de abertura de um "site" — servindo como fonte inicial de conexões, ou seja, como uma porta de comunicação — ou encerra em si mesma todo um conjunto de informações.

O projeto lingüístico que subjaz nas conexões interpáginas ou intrapáginas é entendido como "hipertexto". Segundo Duchier (2000), o hipertexto pode ser definido como um recurso de manejo de informações no qual os dados estão arquivados em uma matriz, cujos nós estão interligados por "links" (ou conexões). Não se trata apenas de uma interface baseada em um mecanismo diferente de acesso; o hipertexto é um esquema de representação, um tipo de matriz semântica, a qual pode reproduzir mecanicamente a construção do pensamento. A principal característica do hipertexto é possibilitar uma organização textual e leitura não-lineares; além disso, o leitor é livre para explorar e assimilar informações por diferentes caminhos. Os nós podem ser compostos por texto, imagem, som, vídeo, gráficos etc.; um hipertexto com multimídia (texto, imagem e som) é denominado de hipermídia (Leão, 1999).

O estabelecimento dessas definições abriu caminho para o ensino a distância. Este pode ser entendido como uma modalidade de ensino-aprendizado 
na qual o estudante e o professor estão fisicamente separados, e a tecnologia (voz, vídeo, dados e impressos) é usada como ponte entre o professor e o aluno (University of Idaho, College of Engineering) ${ }^{1}$. No Brasil, o decreto $\mathrm{n}^{\mathrm{o}} 2.494$, de 10 de fevereiro de 1998, foi considerado o grande instrumento de valorização da educação a distância, definindo-a como: "forma de ensino que possibilita a autoaprendizagem, com a mediação de recursos didáticos sistematicamente organizados, apresentados em diferentes suportes de informação, utilizados isoladamente ou combinados, e veiculados pelos diversos meios de comunicação” (Niskier, 1999. p. 79).

Para Stanton \& Grant (1995), o ensino a distância é qualquer modalidade de ensino preparada por um professor em um dado momento e lugar e utilizada pelo aluno em outro lugar e em outro momento. A essência do curso a distância é ser auto-instrucional e seu material didático deve possuir, dentre outras, as seguintes características: ter objetivos claros, instruções e tempo determinado para execução de cada seção do curso; uso de um estilo pessoal, de conversação; ser estruturado para promover um aprendizado ativo, com exercícios e "feedback" das respostas dos alunos; ser auto-suficiente, para que o estudante possa estudar em casa no horário que desejar; incorporar conteúdos curtos, sem informações desnecessárias; ter um "layout” limpo, que comunique todo o tempo para o estudante que tipo de atividade está sendo desenvolvida.

Outras terminologias constantemente adotadas neste trabalho são “didática" e “interdisciplinaridade". Antolí (2000, p. 84) define didática como

\footnotetext{
${ }^{1}$ Para outras definições de diferentes centros, ver http://www.uwex.edu/disted/definition.html .
} 
"uma ciência e uma tecnologia que se constrói, com base na teoria e na prática, em ambientes organizados de relação e comunicação intencional, nos quais se desenvolvem processos de ensino e aprendizagem para a formação do aluno". Já a definição de interdisciplinaridade é citada por Lenoir (2000) como sendo "a existência de pelo menos duas disciplinas como referência e a presença de uma ação recíproca". Esse autor reforça a necessidade de interação nos processos interdisciplinares.

Com base nessas definições é que nos pautamos para estabelecer a metodologia deste trabalho.

\subsection{Produção de material didático para Internet}

As bases de produção de material didático para Internet devem seguir os mesmos princípios aplicados para "sites" destinados a outras funções, tais como lazer, comércio etc. Um dos estudiosos mais engajados nesse tema é Jakob Nielsen, cuja produção científica denota um trabalho intenso acerca do impacto e da funcionalidade dos novos meios eletrônicos de transmissão das informações. Nielsen (2000) defende a idéia de que um "site" deve ser, antes de tudo, usável. Para ele, isso implica simplicidade, isto é, as páginas devem primordialmente comunicar tudo a todos, sem qualquer esforço do usuário. Isso implica em abrir mão, às vezes, de "layouts" mais bem elaborados e criativos e investir na objetividade das informações. Nielsen ainda reforça que o melhor avaliador do desempenho do "site" é o usuário e recomenda pesquisas constantes que procurem medir o grau de aceitação e de facilidade de manejo das páginas. 
Schultz et al. (2000), da Sociedade Alemã de Informática Médica, Biometria e Epidemiologia, elaboraram um catálogo em que constam os critérios mínimos que as mídias eletrônicas devem possuir para serem aplicáveis à área médica. Os critérios foram baseados nas necessidades do usuário e se aplicam a situações em que predomine o ensino e ou a prática médica. Dentre os inúmeros quesitos elencados, destacam-se: a adaptação do conteúdo ao público; informação quanto a direitos de cópia; o aplicativo deve iniciar sem qualquer sistema de instalação, nem interferir no sistema operacional do computador; figuras grandes devem estar disponíveis em menor tamanho; o acesso aos dados deve ser amigável, havendo uma combinação inteligente entre elementos "online" e "off-line"; uma nova janela do navegador deve ser aberta somente quando houver necessidade, sendo visível essa abertura ao usuário por intermédio da manutenção de estilos diferenciados entre uma janela e outra; a data da última atualização deve estar sempre presente; o conteúdo em texto deve ser consistente e compacto; o "layout", a fonte e a formatação devem mostrar consistência; a regra "um tópico, uma janela" deve ser obedecida sempre que possível; a semântica dos "hiperlinks" deve estar explícita, por intermédio de "links" autoexplicativos; o acesso à informação deve ser direto através de instrumentos de orientação (índices, setas de página anterior e posterior, comentários referentes a textos anteriores e posteriores etc.); deve existir um sistema de busca que contenha as informações de todo o "site"; nas aplicações didáticas, o uso de diferentes formas de apresentação (com vídeo, animações, som, imagens) é preferível em relação a uma apresentação contendo somente texto; a cor do 
fundo e dos elementos de controle devem ser discretas, não interferindo na legibilidade do texto.

O’Dowd (2000) e Lynch \& Horton (2000) — o primeiro da Universidade de Newcastle e o segundo, da Universidade de Yale — elaboraram textos de orientação para docentes que queiram construir páginas para a Internet. Esses textos indicam sobretudo princípios básicos de diagramação de páginas, bem como algumas dicas de linguagem HTML que ajudam a incrementar a interatividade. Melly (2000) também possui um curso de orientação à confecção e manejo de materiais multimídia.

Santaella \& Nöth (1999), envolvidos particularmente com os diferentes significados da imagem e sua linguagem, sugerem que uma nova gramática deva ser desenvolvida para as mídias eletrônicas. A tese defendida pelos autores direciona-se para interpretar a imagem eletrônica como se fosse um som, isto é, um conjunto de pontos luminosos que "acendem e apagam na seqüência temporal", formando um todo pictórico semelhantemente às notas musicais. Se a linguagem das imagens adquire um "status" especial quando digitalizada, é imprescindível considerar isso quando se criam estruturas hipertextuais e, mais ainda, quando se engendram estudos sobre as interfaces computacionais. Essas premissas mereceriam maiores detalhamentos aqui, pois fazem parte de um campo de pesquisas totalmente novo e desconhecido, o qual necessita ser melhor contextualizado em qualquer trabalho que o cite. Contudo, não faremos essa contextualização, por não acharmos conveniente considerando a linha de abordagem apontada aqui. Citamos os autores mais como uma forma de indicar 
as tendências dos estudos envolvendo as interfaces computacionais, as quais parecem fornecer bases interessantes para análises do impacto das novas tecnologias sobre os seus usuários.

\subsection{Contexto envolvendo a implantação de cursos via Internet e programas de ensino a distância}

O Sistema Integrado de Apoio ao Ensino, programa desenvolvido pelas Pró-Reitorias de Graduação e Pós-Graduação da USP, fez um levantamento dos "sites" das unidades de ensino da Universidade de São Paulo direcionado à busca quantitativa e qualitativa dos materiais didáticos disponíveis na Internet (Novelli et al., 2001). Todas as unidades de ensino foram acessadas, tendo-se como critério, primeiramente, examinar cada departamento e, dentro deste, as disciplinas. Uma das conclusões desse relatório foi que os "sites" da área de Exatas contêm mais material disponível em relação à área de Biológicas e de Humanas. Um outro achado foi que provavelmente existam mais materiais do que os acessados pelos responsáveis pelo levantamento, porém esses materiais não se encontram diretamente "linkados" ao "site" da unidade, tendo, portanto, um público mais restrito.

Para comprovar que a Internet já está causando profundas modificações no profissional cirurgião-dentista, Scheleyer et al. (1998) realizaram um estudo no qual submeteram um questionário a profissionais da área odontológica da América e do Canadá. O questionário continha perguntas sobre o grau de conhecimento de informática pelo profissional, os equipamentos e os 
"softwares" utilizados e os métodos de acesso e de utilização da Internet. O questionário foi submetido às 11 maiores listas de discussão em Odontologia da Internet. Um total de 825 respostas retornou de 52 países diferentes, a maioria oriunda do Canadá e dos Estados Unidos. O Brasil foi representado por 2\% de respostas. Sessenta e nove por cento respondeu que seu conhecimento de Internet era alto ou muito alto, enquanto $31 \%$ assumiram como sendo baixo ou muito baixo; $56 \%$ respondeu que acessa a Internet pelo menos uma vez por dia; e somente 19\% utiliza esse meio para educação continuada; a maioria, contudo, declarou que, futuramente, o uso da Internet para essa e outras atividades, como comunicação com pacientes, discussão de casos clínicos e informação sobre diagnósticos, será de grande valia. Os autores concluem que a Internet está se tornando um instrumento de trabalho para os profissionais da área odontológica.

Dowes (1998) discute a influência da Internet sobre o ensino de Odontologia na Inglaterra. Em pesquisa realizada em 1996, somente 37\% dos alunos de graduação em odontologia sentiam-se aptos a usar o computador em seu curso; em 1998, pesquisas realizadas no país demonstraram que 41\% de todas as crianças inglesas tinham computador em casa e que $29 \%$ dos jovens entre 7 e 16 anos usaram a Internet pelo menos uma vez. Dowes ainda comenta que o Comitê de Aprendizado do Governo Nacional Britânico planejou, até o ano 2002, que todas as escolas, bibliotecas, faculdades e universidades inglesas teriam uma rede de comunicação instalada e se comunicariam entre si. Faz parte desse planejamento o treinamento adequado das crianças inglesas para o manejo do computador antes de estas entrarem em contato com as instituições interligadas. 
Uma das idéias na Inglaterra é tornar obrigatória a apresentação de um certificado de habilitação no manejo do computador antes da entrada nas universidades de Odontologia e Medicina. Enquanto essa iniciativa não é oficializada, as escolas de Odontologia na Inglaterra implementam em seus currículos a disciplina de Informática, visando preparar os alunos para o acesso remoto e o auto-aprendizado pelo computador. Dowes (1998) afirma que, até o momento, a inserção da Informática nos currículos odontológicos tem ocorrido de forma aleatória no país, não havendo padronização de temas mínimos a serem abordados. $\mathrm{O}$ autor supõe que esse seja um dos motivos pelos quais o ensino por computador na área da Odontologia ainda não tenha sido de todo implementado e aceito totalmente. A Internet tem sido utilizada pela comunidade odontológica inglesa principalmente para educação continuada; "sites" de simulação de casos clínicos e de atualização têm sido constantemente criados pelas universidades e acessadas por ex-alunos e pós-graduandos. Cursos de pós-graduação, como o PROVIDENT (Postgraduate Regional Online Videoconferencing in Dentistry), têm sido resultado de projetos envolvendo videoconferência via telefonia e Internet, os quais almejam transmitir a distância grande parte do conteúdo programático de disciplinas de pós-graduação (Dowes, 1998).

Scheleyer (1998) lidera um programa na Escola de Odontologia da Universidade de Temple, EUA, que visa introduzir o aluno de graduação no campo da Informática aplicada à Odontologia. O programa iniciou-se em 1991 com a implementação de sistemas computacionais na Escola como um todo, criando-se laboratórios e salas de aula informatizadas. Um dos objetivos 
principais do programa é estabelecer as diretrizes mínimas no campo da Informática necessárias ao ensino e aprendizado da Odontologia. Para tal, foram realizadas reformas estruturais e departamentais para a introdução da Informática no currículo mínimo dos alunos. Os resultados apontados pelo autor acerca desse processo de implementação e difusão dessa disciplina na Odontologia indicam que os alunos, após a implementação do curso, entre 1995 e 1997, acessam em ritmo crescente a WEB; o mesmo se dá, mas em menor grau, quanto ao uso de “e-mail” e de processadores de texto, como o Microsoft Word®. Além disso, dados de questionários respondidos pelos alunos indicam que a disponibilização na Internet ou em Intranet de material didático foi intensamente aprovada, o que encorajou os autores do programa a colocar como meta a criação de cursos "on line". Um dado interessante é que os alunos preferem acessar esse material em casa, e não nos laboratórios disponíveis na faculdade. Atualmente, essa meta já está bem desenvolvida na Universidade de Temple, estando disponível "on line" o próprio curso de Informática e outros cursos².

Holborow \& Kean (1991) descrevem o primeiro curso a distância patrocinado pela Faculdade de Odontologia da Universidade de Otago, Nova Zelândia, o qual ocorria via telefone e correio e cuja implementação deu-se em 1976. O curso destinava-se a sustentar um programa de educação continuada, adquirindo um "status" de pós-graduação, com direito a diploma após um ano de participação nas atividades propostas. Os primeiros resultados após alguns anos de funcionamento indicaram que poucos dentistas matriculados chegaram até o

\footnotetext{
${ }^{2}$ Detalhes desses cursos estão no item "Sites na Internet de escolas de Odontologia com material didático 'on line”” ou no endereço http://www.temple.edu/dentistry/di/ce/index.html .
} 
fim do curso e receberam diploma. Após reformas curriculares e mudanças no programa, em 1985 o curso passou a fazer parte do programa de pós-graduação em Dentística Restauradora da universidade. Os alunos tinham o prazo de três anos para completar os 24 módulos que compunham o curso. Os recursos utilizados foram coletânea de textos, teleconferência baseada somente em áudio, tratamento de pacientes sob supervisão de tutores e residência em escolas. Segundo os autores, praticamente 24 pessoas, empregadas pela instituição, estavam diretamente envolvidas com o curso; indiretamente, o curso atingiu 1/3 de todo o pessoal docente e administrativo da faculdade. A principal vantagem desse curso apontada pelos autores foi a possibilidade de os alunos aprenderem e se informarem diretamente em seu ambiente de trabalho, fazendo a parte prática do curso até mesmo em seus próprios pacientes, desde que estes estivessem devidamente esclarecidos acerca da finalidade de aprendizado. Os custos para os estudantes revelaram-se satisfatórios, mas, para a Universidade, elevou-se em termos de mão-de-obra. Segundo os autores, essa experiência com ensino a distância foi a primeira na área de Odontologia em todo o mundo.

Radford (1994) descreve um programa disponível na Open University (Inglaterra) dedicado a preparar os profissionais da área médica a administrar mais eficazmente suas ações e a das pessoas que os rodeiam, sua estrutura de trabalho e o ambiente externo. O curso, realizado via Internet com duração de 220 horas (cerca de seis meses), já foi feito por cerca de 4000 pessoas em todo o mundo. $\mathrm{O}$ autor demonstra a importância do contato com esse tipo de informação para os cirurgiões-dentistas. O curso tem a maioria de sua estrutura 
baseada na leitura de livros; fitas de vídeo e áudio são utilizados como instrumentos complementares. Cada aluno possui um tutor, responsável pela direção dos estudos e pelas avaliações parciais e final; esta é feita em um fim-desemana em um hospital, como uma residência.

$\mathrm{Na}$ Universidade de Kentucky também foi criado um programa de educação continuada para pós-graduandos baseado em ensino a distância (Smith et al., 1998). Para compor o curso, foram feitas perguntas a 40 dentistas quanto às suas necessidades de complementação profissional. Para chegar a um consenso quanto à escolha das matérias, os autores utilizaram um sistema denominado Técnica Delphi (Smith et al., 1995), o qual trabalha com triagens múltiplas para atingir uma "inteligência coletiva", ou seja, uma convergência de opiniões. As matérias escolhidas foram, dentre outras, ortodontia, dor orofacial, dentística restauradora e odontologia geriátrica. $\mathrm{O}$ curso tinha duração de três semestres, ao final dos quais o aluno recebia um certificado e tinha computados, em outros programas de pós-graduação, os créditos atingidos. Os recursos utilizados foram vídeo digital submetido a filtros de compressão e passível de transmissão a distância via linha telefônica, clube eletrônico de estudos formado a partir de um centro de computação na Faculdade, troca de textos e imagens via Internet e supervisão do tutor diretamente na Faculdade em dias predeterminados. Todos os alunos matriculados (total de 13) terminaram o curso; a média de idade dos participantes era de 30 anos, com cinco anos de experiência na clínica. Segundo avaliação realizada por meio de questionários aplicados aos alunos, houve um entusiasmo geral e aprovação. Os autores colocam como ponto principal da 
experiência a interação a distância promovida pelo uso dos vídeos, fator considerado essencial para o sucesso do projeto.

A maioria dos cursos "on line" está baseada em material didático construído sob a forma de hipertexto. A aplicação de "hiperlinks" em uma estrutura de hipertexto exige a adoção de uma hierarquia de conexões, de modo a construir uma árvore de significados. O uso do hipertexto implica, assim, o estabelecimento de um protocolo de conexões hierárquicas que atinge diretamente a estruturação curricular. Monteith (1998) descreve um modelo de estruturação de "links" baseado na concepção nosológica de Gabrieli (1995) apud Monteith (1998). Nesse modelo, encontram-se seis níveis de agrupamentos de disciplinas com objetivos comuns: no primeiro nível, o modelo posiciona as disciplinas envolvidas com a estrutura biológica normal, quais sejam, histologia e anatomia; no segundo nível, localizam-se as matérias dedicadas ao estudo das funções normais, fisiologia e bioquímica; no terceiro nível, ficam as disciplinas dedicadas ao reconhecimento e à descrição das doenças, envolvendo a patologia, radiologia, semiologia e microbiologia; o quarto nível é dedicado à prevenção das doenças; o quinto, à eliminação destas, incluindo principalmente a cirurgia; e o sexto, à reabilitação da forma e da função, estando localizadas as matérias de dentística e de prótese. Com esse modelo, o autor conseguiu estabelecer um protocolo de conexões por palavras-chaves em uma estrutura de hipertexto, para criar um programa eletrônico dedicado ao ensino de matérias da área odontológica. A aplicação desse modelo atinge diretamente a estrutura curricular tradicional. 


\section{4 "Sites" na Internet de escolas de Odontologia com material didático "on line"}

Em consulta aos principais sistemas de busca de uso comum disponíveis na Internet $t^{3}$ foi possível detectar, no Brasil, cerca de 500 "sites" relacionados à Odontologia registrados nesses sistemas. A maioria deles destina-se a compra e venda de produtos $(60 \%)$, incluindo nesse grupo as propagandas de clínicas odontológicas; $20 \%$ deles pertencem a entidades e instituições da área odontológica, com conteúdo sobre a estrutura geral dessas organizações; $10 \%$ têm como conteúdo publicações de periódicos e catálogos com enfoque científico; 3\% referem-se a eventos e campanhas promovidos por entidades públicas e privadas; $5 \%$ contêm temas relacionados a entretenimento (lazer, esporte, "sites" de turmas de faculdade) e somente $2 \%$ destinam-se à educação, seja para a comunidade, seja para profissionais ou estudantes da área.

Preston (1997) confirma esses dados complementando que, segundo o site http://www.dentalsite.com, estavam listadas "homepages" de 51 faculdades dos Estados Unidos e 35 de 15 de outros países. O mesmo autor afirma que muitas dessas "homepages" possuem conteúdo referente a matérias ministradas, o qual pode ser livremente acessado pelos alunos. Contudo, o autor acredita que a grande maioria dessas iniciativas de produção de material didático "on line" restringe-se a ambientes Intranet (definida, segundo o autor, como uma rede que interliga internamente uma dada organização, protegida dos acessos externos a ela). As vantagens da Intranet sobre a Internet residem no maior controle e na

\footnotetext{
${ }^{3}$ (http://www.cade.com.br ; http://www.altavista.com.br ; http://www.excite.com.br)
} 
maior velocidade de transmissão de informações; além disso, recursos de personalização — como a criação de contas particulares dos alunos — são mais viáveis operacionalmente.

Em 1996, Scheleyer afirmou que muitas escolas de Odontologia estavam inadequadas ou não totalmente preparadas para a aplicação dos recursos eletrônicos disponíveis; muitas delas não tinham nem infra-estrutura nem pessoal qualificado para a implementação de tais recursos. O autor ainda enfatizou que a maioria das iniciativas envolvendo o uso de instrumentos computacionais na área odontológica estava partindo de empresas comerciais, raramente fazendo parte de projetos acadêmicos.

As principais universidades americanas e européias parecem estar mudando essa situação atualmente, como atesta o levantamento de "sites" dessas escolas realizado via Internet e descrito a seguir. Pela grande quantidade de informações e de escolas de Odontologia no mundo inteiro, a pesquisa restringiuse à seleção de escolas norte-americanas listadas no trabalho de Preston (1997) e às principais escolas de odontologia européias, escandinavas, australianas e latinoamericanas. Informações de outras escolas também foram colhidas a partir dos "sites" consultados. A estratégia de busca priorizou, primeiramente, a visita ao departamento que contivesse a disciplina de patologia e, secundariamente, a projetos de educação continuada ou de educação a distância apontados no "site". 


\subsubsection{Escolas de Odontologia norte-americanas}

Já em 1996, a Universidade do Estado de Ohio tinha disponível na Internet um curso completo de Prótese Total, com possibilidade de acesso a todo o conteúdo programático da disciplina, informações sobre projetos realizados e alguns testes que envolviam a simulação de casos clínicos e a criação de planos de tratamento (Putten Jr., 1996). Além disso, os alunos eram orientados pelo "site" a tirar fotografias digitais de si mesmos e a realizar medidas cefalométricas; posteriormente, essas fotos ficavam disponíveis na rede para eventuais comparações e discussões.

A Faculdade de Odontologia da Universidade de Creighton (EUA) ${ }^{4}$ possui um programa de educação continuada via Internet utilizando vídeos digitais com sistema de alta compressão. O usuário, após ver o (s) filme (s) do curso no qual se matriculou, faz um teste e o envia por "e-mail” para o professor responsável por sua matrícula. Os vídeos duram, em média, 50 min. Se o usuário passar no teste, recebe um certificado. Esses cursos são pagos e reconhecidos pelo Programa de Reconhecimento de Educação Continuada da American Dental Association. Para o usuário visitante do "site", estão disponíveis dois cursos como exemplo: um de manejo de pacientes em Odontopediatria e outro de análise oclusal da dentição mista.

A Internet também é utilizada como instrumento de educação continuada por outras universidades americanas. É o caso da Escola de Odontologia da Universidade de Indiana, a qual já tem cursos "on line”, pagos e com emissão de

\footnotetext{
${ }^{4}$ ( $\underline{\text { http://cudental.creighton.edu/) }}$
} 
certificados. Como exemplo no "site" está disponível somente um curso na área de Endodontia, o qual é gratuito. Na grade horária, encontram-se disciplinas de Patologia Oral e Maxilofacial, as quais somente são acessáveis mediante matrícula prévia.

Já na Faculdade de Odontologia da Universidade de Baylor há páginas estruturadas a partir dos recursos do Microsoft Power Point ${ }^{\circledR}$, com a intenção também de promover educação continuada, agora a partir de um sistema "on line" semelhante à apresentação de diapositivos ${ }^{6}$. Uma apresentação sobre exame radiográfico de cárie dental e uma sobre exame semiológico para detecção de neoplasias malignas na cavidade oral estão disponíveis para qualquer visitante. Nessas apresentações, há somente imagens e texto, sem outros recursos de multimídia ou de animação. Na mesma faculdade há um centro de TeleSaúde (Center for TeleHealth), dedicado a promover transmissões a distância utilizando telecomunicações interativas e imagens, áudio e dados em formato digital. A iniciativa inclui consultas, diagnóstico e plano de tratamento, serviços de saúde oral e pesquisas em diversas áreas. A comunicação é feita por intermédio de satélites e redes digitais baseadas em Windows NT®. São realizadas transmissões diárias, com hora marcada, destinadas à pós-graduação.

Um centro de TeleOdontologia também foi estruturado na Faculdade de Odontologia da University of North Carolina at Chapel Hill' ${ }^{7}$, com a mesma

\footnotetext{
5 ( http://www.iusd.iupui.edu/ www/ce/online/)

${ }^{6}$ (http://www.tambcd.edu/DentalCE/Distance Learning/distance learning.html)

7 (http://www.dent.unc.edu/Depts/diag/newsletter/newslett.htm $)$
} 
finalidade do centro da Universidade de Baylor. São apresentados casos clínicos de radiologia e feitas propostas de diagnóstico diferencial via “e-mail".

A Universidade de Colúmbia, a Universidade da Pensilvânia e a Universidade de Harvard formaram um consórcio (Ivy Dental Consortium) ${ }^{8}$ para implementar programas inovadores dedicados a preparar o cirurgião-dentista para sua prática diária. Para tal, utilizaram o recurso de apresentação de caso clínico e proposta de tratamento via Internet: o usuário propõe um plano de tratamento e depois o compara com o realizado. No "site" está disponibilizado somente um caso de doença periodontal, como exemplo. Esse programa faz parte de iniciativas particulares em cada uma dessas universidades, como a Columbia University, que possui um centro de educação a distância na Faculdade de Engenharia e Ciências Aplicadas (Columbia Video Network) ${ }^{9}$. Esse centro é destinado a alunos de pós-graduação, os quais podem matricular-se em inúmeras disciplinas e cursá-las a distância. A aprovação nessas matérias possibilita a contagem dos créditos equivalentes. $O$ aluno pode, assim, mesclar em seu programa de pós-graduação métodos de aprendizado a distância com os tradicionais. As matérias disponíveis são, em sua maioria, da área de exatas, havendo algumas da área de Línguas.

Disciplinas de pós-graduação com validação de créditos também podem ser acessadas via Internet e Intranet na Medical University of South Carolina. Essa Universidade possui um centro de ensino a distância destinado a atender

\footnotetext{
${ }^{8}$ (http://www.ivydental.org )

9 ( http://www.cvn.columbia.edu )
} 
programas de educação continuada em diversas áreas médicas ${ }^{10}$. O usuário se inscreve na disciplina via rede, comunicando-se com seu tutor por "e-mail". $\mathrm{Na}$ área de Odontologia, está disponível um curso de terapêutica medicamentosa e um curso de Prótese Fixa I, destinado à graduação. Para acessar esse curso e outros, é necessária senha. O "site" é composto por texto e imagens, com alguns recursos de animação. Em termos de estrutura organizacional, esse centro parece ser o mais bem desenvolvido de todos os já consultados específicos na área de Odontologia.

Estrutura semelhante também está disponível na Faculdade de Odontologia da Universidade de Illinois, Chicago"11. Os cursos “on line” criados fazem parte de um extenso programa de educação continuada e recebem o selo de aprovação da American Dental Association.

Em Connecticut, a Faculdade de Odontologia sedia o projeto D.E.N.T.A.L., destinado ao desenvolvimento de estrutura pedagógica utilizando os recursos eletrônicos atuais ${ }^{12}$. Sua principal função é orientar os docentes à produção de material didático.

No tocante à existência de centros de informática específicos para a área da Odontologia e que estão desenvolvendo atividades em prol da implantação de sistema de ensino a distância, a Faculdade de Odontologia da Temple University, Pensilvânia, parece ser a mais engajada nesses projetos. Ela possui um centro de educação continuada no qual são realizados programas de aperfeiçoamento e de

\footnotetext{
${ }^{10}$ ( http://www.edserv.musc.edu/de// )

${ }_{11}$ (http://dentistry.uic.edu/courses/ )

${ }_{12}$ ( http://SDM.UCHC.edu/ProjectD/Roadmap.html )
} 
pós-graduação. Estão disponíveis também cursos "on line", os quais podem ser acessados via Internet, como um de histologia do periodonto ${ }^{13}$ e um de informática em odontologia ${ }^{14}$. Esses cursos são destinados a alunos de pósgraduação e de atualização em clínica geral; alguns são indicados também para alunos de graduação. A maioria dos cursos foi concebida utilizando-se recursos do Microsoft PowerPoint ${ }^{\circledR}$ e trabalhando-se com texto, imagens, listas e grupos de discussão ("chats"). O curso de informática é composto por três módulos, cada um deles valendo determinado número de créditos. O candidato, após registrar-se via Internet, recebe uma senha com duração de seis semanas, tempo para completar cada módulo. Ao final, o candidato faz um teste também "on line" e recebe um certificado.

Material didático “on line” específico na área de Patologia Geral aplicada à Odontologia e Patologia Bucal praticamente não existe disponível atualmente, pelo menos no ambiente da Internet. Os "sites" encontrados que mais se enquadram nessas especialidades são das Faculdades de Odontologia das Universidades de Iowa ${ }^{15}$, de Kentucky ${ }^{16}$ e da Pensilvânia ${ }^{17}$. Em Iowa, está disponível um "site" contendo um atlas de lesões bucais. O acesso é feito por intermédio de um índice composto pela nomenclatura das lesões; ao clicar, surgem ícones de imagens clínicas e microscópicas, as quais podem ser visualizadas em grande aumento. Um pequeno texto explicativo acompanha cada

\footnotetext{
${ }^{13}$ ( http://temple.edu/dentistry/perio/periohistology/)

${ }^{14}$ ( http://www.temple/edu/dentistry/di/ce/ )

${ }^{15}$ ( http://www.iowa.edu/ oprm/AtlasHome.html )

${ }_{16}$ ( http://www.uky.edu/ cmiller )

${ }_{17}$ ( http://pathology.dental.upenn.edu/path615)
} 
imagem. Cada página possui de dois a quatro quadros ("frames"), conferindo dinamismo à interface. Em Kentucky, também é possível acessar um atlas das lesões bucais mais comuns. Há imagens clínicas e textos referentes a cada entidade patológica. $\mathrm{Na}$ Internet, é possível acessar uma versão reduzida da apresentação, a qual é comercializada pela Universidade via CDROM. Neste, além de imagens e texto, é possível também acessar vídeos. Por fim, na Pensilvânia, é possível acessar material didático "on line" específico de Patologia Geral. A maioria do conteúdo parece estar disponível somente em ambiente Intranet. Faz parte do material também a possibilidade de participação em seminários e testes via rede.

No Canadá, somente a Faculdade de Odontologia da Universidade de Western Ontario disponibilizou na Internet material didático; é possível visualizar imagens histológicas e textos sobre os tecidos da boca. O aluno acessa as imagens via galeria e, depois, faz testes de múltipla escolha, como avaliação de seu aprendizado $^{18}$.

\subsubsection{Escolas de Odontologia escandinavas, japonesas, européias e australianas}

Um "site" interessante para consulta de escolas com material didático disponível na Internet pertence ao Instituto Karolinska, na Suécia. Nesse instituto, há uma página ${ }^{19}$ contendo diversos "links" para escolas da área de saúde,

\footnotetext{
${ }^{18}$ ( http://www.canweb.ca/drgalil )

19 ( http://www.mic.ki.se/Medimages.htm )
} 
principalmente dinamarquesas, suecas, alemãs e japonesas. A maioria deles leva a materiais tipo atlas, contendo fotos e texto, tanto na área de odontologia quanto nas diversas especialidades médicas.

Por esse "site", pode-se chegar à Escola de Odontologia da Universidade de Nagasaki, no Japão. No departamento de Cirurgia Oral e Maxilofacial dessa escola, estão disponíveis páginas contendo casos clínicos com ênfase no diagnóstico radiológico, com fotos de muito boa qualidade ${ }^{20}$.

$\mathrm{Na}$ Inglaterra, a Escola de Odontologia da Universidade de Glasgow possui um curso de Prótese Removível e um de Biologia Oral "on line" em ambiente Intranet. $\mathrm{Na}$ mesma faculdade, há um centro (Dental Innovative Educational Technology) destinado a dar apoio ao desenvolvimento de material didático eletrônico ${ }^{21}$.

Um centro semelhante existe na Faculdade de Odontologia da Universidade de Newcastle, o qual patrocina cursos a distância em ambiente Intranet. É possível acessar esses cursos somente em rede local22.

$\mathrm{Na}$ Faculdade de Odontologia da King's College of London também existem projetos de produção de material didático. Como exemplo na Internet, há um pequeno curso de Patologia Bucal, baseado em fotos e textos; alguns arquivos estão em formato $\mathrm{PDF}^{23}$.

Algumas universidades européias estão se unindo para o desenvolvimento de projetos que visam à modernização do ensino. É o caso do Lucas Project, uma

\footnotetext{
${ }^{20}$ ( http://w3.dh.nagasaki-u.ac.jp/tf/disease.html )

21 ( http://cal-serv.dental.gla.ac.uk/diet/)

22 (http://www.ncl.ac.uk/ nresdent/ )

23 ( http://www.kcl.ac.uk/depsta/dentistry/ompmi/contents.html )
} 
iniciativa das Universidades de Copenhagen, Lund e Sheffield, com o objetivo de estruturar e desenvolver uma rede multimídia de material didático. Um exemplo das ações do projeto encontra-se disponível na Internet: trata-se de um conjunto de fotos e de textos sobre tumores odontogênicos, cuja concepção parece ser muito boa ${ }^{24}$.

Na França, a Faculdade de Odontologia da Universidade de Nancy disponibilizou um conjunto de fotos e textos sobre lesões bucais em pacientes com AIDS. Todas as imagens foram cedidas pelo Prof. J. J. Pindborg, do Royal Dental College, Copenhagen. Essas páginas não parecem ser muito bem concebidas $^{25}$.

Por fim, na Austrália, não foi possível acessar nenhuma escola de odontologia que contivesse material disponível na Internet.

\subsubsection{Escolas de Odontologia latino-americanas}

Praticamente não existe produção concreta de material didático "on line” nas escolas de Odontologia latino-americanas. Na Universidade de Buenos Aires, Argentina, há um programa de educação a distância que visa promover, via rede, cursos referentes a matérias do ciclo básico da Universidade. Os alunos acessam as informações a distância e podem consultar nas bibliotecas bancos de dados de áudio e vídeo. A avaliação é realizada nas salas de aula e com a presença do tutor $^{26}$.

\footnotetext{
${ }^{24}$ ( http://www.odont.ku/dk/lucas/main.html )

${ }_{25}$ ( http://www.uhp.u-nancy.fr/odonto/odonto.htm )

${ }^{26}$ ( http://uba.ar/UBA21/homepage.html )
} 
A Universidade de Concepción, juntamente com a Universidade do Chile, também possuem um programa semelhante, sediado em um laboratório de multimeios ${ }^{27}$. Não estão disponíveis nem material didático nem resultados do programa, o qual parece estar ainda em implantação.

No Brasil, o Departamento de Morfologia da Faculdade de Odontologia de Ribeirão Preto da USP disponibilizou material didático “on line" em anatomia e histologia 28 .

Na Faculdade de Odontologia da Universidade de São Paulo, o ensino a distância tem sido realizado mais por via analógica em rede interna. Cirurgias são feitas em centro cirúrgico e demonstradas ao vivo e em tempo real em várias salas ao mesmo tempo. A sistemática de aplicação desse sistema já foi formalizada por Novelli \& Corrêa (1999). A necessidade de um protocolo de ensino a distância para as faculdades de odontologia brasileiras também já foi apontada pelos autores. Vale dizer que a primeira iniciativa de transmissão de dados a distância foi realizada por Novelli \& Araújo em 1981, em que foi feito diagnóstico via satélite entre São José dos Campos - SP e a Barreira do Inferno $\mathrm{RN}$.

\section{5 Alguns dados obtidos a partir de cursos "on line" na área médica}

Gjerde \& Shapleigh (1999) analisaram o grau de participação de dentistas, auxiliares de enfermagem, farmacêuticos e assistentes de saúde primária em cursos de educação continuada e em ensino a distância nos últimos três anos.

\footnotetext{
${ }^{27}$ ( http://www.edu.udec.cl/primeiraprueba11.html )

${ }^{28}$ (http://www.forp.usp.br/mef $)$
} 
Esses profissionais trabalhavam em regiões rurais de Wisconsin, onde receberam uma carta contendo um questionário referente à pesquisa. Cerca de $99-100 \%$ dos respondentes ao questionário já tinham participado de algum curso de educação continuada, porém uma minoria tinha feito algum curso a distância (cerca de 29 a 57\%, dependendo do grupo de profissionais), envolvendo conferência via telefonia, áudio e videoconferência e curso pela Internet. Nenhum dentista tinha participado de conferências a distância. Os interesses nas tecnologias de ensino a distância foram, primeiramente, pela Internet e, em segundo lugar, pela televisão, vindo em seguida, a áudio e videoconferência. Os dentistas e os médicos foram os mais interessados nessas tecnologias.

O Centro de Educação Médica da Inglaterra (Simpson et al., 1999) desenvolveu um programa de reciclagem de especialistas utilizando o ensino a distância. Foi criado um "site" contendo exercícios de diagnóstico de doenças respiratórias a partir de casos clínicos, testes de múltipla escolha abordando diversas áreas médicas, um questionário sobre radiologia e instrumentos de interatividade (grupos de discussão, lista de "links" para outros "sites" etc.). Fez parte do programa também a coleta de dados dos participantes no tocante às dificuldades encontradas no curso e à forma de uso do computador. Um dos resultados foi a detecção da necessidade da disciplina de informática no curso de graduação em Medicina, a qual atualmente já é parte obrigatória do currículo na Inglaterra. Um dos impactos educacionais do curso foi o empenho dos participantes em aumentar seu escore de pontos nos exercícios de casos clínicos e de radiologia, repetindo mais de uma vez essa atividade. 
Para verificar o grau de eficiência da Internet para os cursos de educação continuada na área médica norte-americana, Peterson (1999) avaliou os "sites" de 205 organizações que oferecem esse tipo de curso "on line". O autor verificou que metade dessas organizações são escolas de Medicina, porém poucas mantêm esses "sites". Os "sites" comerciais, ao contrário, representando $25 \%$ dos analisados, oferecem muito mais cursos a distância, o que significa, pela interpretação do autor, que as escolas estão perdendo a liderança em promover educação continuada pela Internet (essa mesma afirmação foi feita por Scheleyer (1996) com referência às escolas de Odontologia, conforme mencionado à pág.21). Além disso, Peterson considerou em sua avaliação a credibilidade do curso - identificação da autoria do material disponível, adequação do material à proposta do curso e sua atualização etc. —, encontrando pouco menos de $70 \%$ dos "sites" com esses quesitos mínimos obedecidos. Um outro dado foi que os "sites" acadêmicos não eram melhores que os comerciais no tocante aos critérios estipulados. O autor concluiu que as organizações comerciais promovem cursos de educação continuada com qualidade, porém sem um delineamento pedagógico adequado; as organizações acadêmicas, por outro lado, possuem as informações necessárias a um curso balanceado e com objetivos claros, porém não dispõem de infra-estrutura para a manutenção desses cursos. O responsável pelo controle de qualidade dos cursos fica em aberto na opinião do autor, uma vez que ambas as pontas que sustentam o sistema estão ainda deficientes.

Um programa envolvendo a conexão "on line" de oito universidades de Medicina na África está sendo liderado pelo Royal College of Surgeons e por 
outras instituições sediadas na Inglaterra e em Vancouver (Heald \& Kelly, 2000). O programa visa preparar os médicos jovens da África, fornecendo material didático e cursos a distância.

O ensino a distância utilizando vídeo tem sido considerado efetivo já há 20 anos pelo Departamento de Educação da Southern California School of Medicine. Com um programa que durou dois anos (1994-1996), a mesma faculdade realizou um curso para residentes utilizando vídeo digital e Internet, cujos resultados revelaram uma interação satisfatória entre os tutores e os alunos e necessidade de maior visualização entre ambos, utilizando, por exemplo, videoconferência (Heestand et al., 1996).

Especificamente na área de patologia, o ensino a distância tem envolvido também a chamada telepatologia, um sistema que visa transmitir a distância dados diagnósticos (radiografias, tomografias e, principalmente, imagens histológicas). Essa transmissão é ainda acompanhada de um conteúdo didático que visa a educação. Landman et al. (2001) apresentam alguns projetos com telepatologia, dentre eles um "site" envolvendo a discussão de casos clínicos com grande interatividade e um microscópio virtual, em que o usuário pode fazer ajustes de luz e foco, bem como acessar maiores aumentos de regiões específicas da imagem histológica. Esse sistema de microscópio virtual utiliza um recurso bem moderno de imagem desenvolvido pela Eastman Kodak, Hewlett-Packard, Live Picture e Microsoft, o qual é denominado de FlashPix. Com esse recurso, é possível dividir uma imagem que está em alta resolução em pequenos blocos; o usuário, ao clicar em uma região da imagem, aciona um desses blocos, e este fica 
visível a ele sob a forma de "zoom" sem a necessidade de dar "download" da imagem original (a qual, como dissemos, está em alta resolução). Essa solução em que se acessa partes de uma imagem mantendo-a inteira sem prejuízo da acessibilidade é muito útil e aplicável à Internet.

\subsection{Questões gerais sobre educação utilizando o computador}

Alguns indicadores do impacto da tecnologia computacional têm sido apontados por pesquisadores que desenvolvem projetos dedicados à educação pública primária e secundária.

Um dos trabalhos mais interessantes nesse campo foi o do Projeto ACOT (Salas de Aula do Futuro da Apple), iniciado em 1985 com as escolas públicas dos Estados Unidos. Esse projeto foi fruto da colaboração de pesquisa e desenvolvimento entre escolas públicas, universidades, órgãos de pesquisa e a Apple Computer Inc., sendo concluído em 1995. Suas metas eram principalmente introduzir os computadores em sala de aula e avaliar o impacto dessa introdução sobre estudantes e professores. Dentre as inúmeras conclusões do projeto, destaca-se o papel essencial do professor como mediador entre a criança e a máquina, a transformação da sala de aula em um híbrido envolvendo ensino tradicional e não-tradicional e os limites de uma estratégia pedagógica em que predomina a instrução e a construção (Sandholtz et al., 1997). Esses dados serviram de base para outros projetos desenvolvidos nos Estados Unidos, mais recentemente relacionados ao ensino a distância. Vale dizer que atualmente cerca de $95 \%$ das escolas públicas dos Estados Unidos estão conectadas pela Internet e 
que $10 \%$ dos professores dessas escolas consideraram-se excelentes usuários dessa ferramenta $(53 \%$ dos professores acharam-se medianamente preparados para empregá-la no ensino) (Cooper, 2000).

Em um trabalho envolvendo estudantes do colegial que nunca tinham acessado o computador, Horvath \& Teles (2000) relatam suas observações ao aplicarem um curso a distância para esses alunos. Verificaram que a maioria dos estudantes demonstrou interesse na experiência quando de seu início, mas, à primeira dificuldade encontrada no computador, impaciência e sentimento de culpa de ter provocado um erro qualquer na máquina eram revelados pela maioria dos alunos. Aos poucos, eles mesmos foram resolvendo esses problemas, não constituindo mais um empecilho no curso ao término da primeira metade deste. Um fato interessante foi a necessidade que os estudantes sentiram em imprimir todas as informações da tela quando estas ultrapassavam 350 palavras. Os depoimentos dos alunos quanto a essa questão giraram em torno da dificuldade que tinham em ler na tela e da necessidade de acessar o conteúdo mais tarde. Os autores concluem que qualquer iniciativa de ensino utilizando o computador deve ter um projeto que contemple a criação de uma interface consistente e a inserção, logo no início do aprendizado, de procedimentos de emergência que permitam a resolução de problemas operacionais.

Iniciativas desse porte têm sido realizadas também no Brasil, como a de Registro et al. (2001), que testaram a potencialidade da Internet para o ensino de Física em uma escola pública de Ribeirão Preto. Apesar de enfrentarem problemas de infra-estrutura (poucos microcomputadores para os alunos, acesso 
restrito à Internet etc.), os autores concluíram que as páginas da Internet aumentaram o interesse dos alunos pela matéria, principalmente quando estas permitiam maior interação.

Um outro trabalho é a experiência com curso a distância do Seminário Teológico Presbiteriano do Rio de Janeiro (Azevêdo, 2000), a qual é interessante por relatar, com detalhes, as dificuldades encontradas por alunos e professores. Azevêdo concentra suas análises no fato de o ambiente de ensino virtual ser "multissíncrono" (síncrono e assíncrono ao mesmo tempo). A temporalidade que é experimentada nesses ambientes é de natureza diversa e diferente da introduzida pela escrita. Os índices de evasão do curso (na ordem de 30\%) foram explicados pelo autor com base nessa discussão quanto ao tempo: para o autor, a desistência vinha do fato de que os alunos não estavam sabendo administrar esse novo tempo do curso, ou seja, não conseguiam ajustar sua disponibilidade de tempo com o ambiente síncrono/assíncrono ao qual estavam sendo submetidos. Um outro ponto discutido pelo autor é o fato de que o aluno fora ambientado desde a pré-escola a ser um receptor de conteúdos, e não um analítico; não sabia, portanto, como se portar diante do novo curso, manifestando resistência quanto ao modelo pedagógico que visa um aluno ativo, naturalmente revelado nos cursos pela Internet, devido às inúmeras possibilidades de navegação e de acesso ao conteúdo inerentes a essa ferramenta.

O autor ainda cita a participação dos professores nesse modelo: sendo pastores a maioria do Seminário, já tinham assimilado seu papel de animadores na comunidade, em que procuram estimular a interação. O conceito de comunidade 
virtual para Pierre Lévy (Lévy, 1993) é exatamente esse adotado pelos pastoresdocentes do Seminário. Se estes fazem isso na vida real, na virtual essa vocação suscitou uma fecundidade pedagógica não prevista, em que os animadores promoveram um grande intercâmbio entre os estudantes utilizando os recursos de interatividade da Internet. Essa vocação do pastor, para o autor, seria de grande valia para o desenvolvimento da Pedagogia nesses novos modelos.

Vieira (2000) faz um breve relato sobre as transformações que os novos paradigmas informáticos acarretam sobre a educação. Nesse relato, cita a linha filosófica do construtivismo, desenvolvida por Piaget, e a do construcionismo, pregada por Papert. No construtivismo, o aluno deve construir seu próprio conhecimento, utilizando para isso ações que potencializam sua capacidade imaginativa e criativa. O construcionismo vale-se dessa intenção de Piaget e inclui o computador como uma ferramenta que auxilia essas ações dos estudantes, sendo um recurso de aprendizagem (Valente, 1998 apud Vieira, 2000).

Gomez (2000) fez uma revisão dos procedimentos de avaliação aplicados na educação baseada na Internet. Ao analisar diferentes "software" de ensino a distância (como WebCT ${ }^{\circledR}$, TopClass ${ }^{\circledR}$, AulaNet ${ }^{\circledR}$ etc.), a autora descreve que a maioria deles realiza um "tipo de cartografia simultânea do desempenho do aluno no curso"; eles mapeiam o desenvolvimento das atividades do professor e do aluno de modo a criar uma história mais ou menos linear de suas ações. Esses recursos são importantes para traçar um perfil do aluno, mas dizem pouco do seu desenvolvimento individual e social durante o curso. A maioria dos "software" considera estratégias de ensino e avaliação que podem ser diagnósticas — em que se procura revisar aprendizagens prévias por intermédio de atividades lúdicas e 
humorísticas, anedotas, situações hipotéticas etc. - - de apresentação da informação — analogias, comparações, destaque de pontos-chaves de um conceito e de suas inter-relações, descrição de ilustrações etc. —, de participação do estudante — diálogo com o tutor, "chats", fóruns, debates etc. — e avaliação por testes - basicamente condutistas, podendo ser de combinação, verdadeiro/falso, múltipla escolha etc., com correção automática. Diante das limitações pedagógicas de avaliação desses programas, Gomez ressalta a importância de atividades lúdicas que provoquem maior desafio aos estudantes por intermédio de conflitos teóricos. Nesse caso, a avaliação se pautará na atividade colaborativa do aluno em promover intercâmbio e adição de novas informações para toda a rede do curso.

Santos et al. (2000) também fazem uma descrição, agora técnica, dos principais gerenciadores de ensino a distância existentes no mercado. Os autores demonstram principalmente o grau de apoio ao professor e ao aluno que esses sistemas possuem, concluindo que estes mantêm ainda um perfil conservador quanto à sistemática de gerenciamento, sendo inadequados, em termos pedagógicos, às demandas educacionais atuais.

Essas experiências e a opinião de educadores envolvidos com o ensino fundamental são importantes para nortear também os trabalhos com ensino a distância no ensino superior. 
PROPOSIÇÃO 


\section{PROPOSIÇÃO}

Este trabalho visa analisar a mudança de paradigma do ensino de Patologia para a graduação em Odontologia, realizada por intermédio do estabelecimento de sistemática de ensino a distância via Internet. Para tal, fazem parte desta proposta os seguintes itens:

- detecção das habilidades dos graduandos em Odontologia no manejo do computador e da Internet, bem como da sua vontade em acessar o material das disciplinas de Patologia pela Internet;

- estruturação de banco de dados digitais e de "sites" referentes às disciplinas de Patologia Geral e Patologia Bucal da FOUSP;

- criação de um protocolo de ensino-aprendizado pela Internet aplicado à área de Patologia (Geral e Bucal);

- aplicação dos “sites” para alunos de graduação;

- análise dessa aplicação principalmente no que concerne à interdisciplinaridade. 
MATERIAL E MÉTODOS 


\section{MATERIAL E MÉTODOS}

Todas as etapas a seguir explicitadas foram realizadas no Laboratório de Informática Dedicado à Odontologia da Disciplina de Patologia Geral da Faculdade de Odontologia da Universidade de São Paulo. Essa metodologia foi previamente submetida ao Comitê de Ética da FOUSP, recebendo aprovação deste.

\subsection{Análise da relação do aluno de graduação com o computador e a Internet}

Um breve questionário foi entregue aos alunos de graduação dos cursos diurno e noturno, matriculados, respectivamente, nas Disciplinas de Patologia Geral e Patologia Bucal (Questionário A.1, Anexo A, pág. 156). O questionário visou a avaliação da relação dos alunos com o computador e o acesso à Internet, sendo composto pelos seguintes itens: dados pessoais (sexo, idade, nome completo e "e-mail"); presença de computador em casa; "softwares" utilizados; freqüência de acesso à Internet; motivos de não utilizar a Internet; finalidade de acesso à Internet; tipos de "sites" mais visitados; desejo de acessar a Internet para consulta das matérias de Odontologia. Os dados coletados foram quantificados utilizando-se o "software" Microsoft Excel®, obtendo-se resultados que nortearam a conduta estabelecida para o teste dos "sites" (item 4.6). 


\subsection{Criação de banco de dados digitais}

Previamente à confecção do conteúdo dos "sites" das disciplinas de Patologia Geral e Patologia Bucal, foram estruturados bancos de imagens e de textos.

Para compor o banco de dados digitais da Disciplina de Patologia Bucal, foram coletadas radiografias, tomografias, diapositivos e fotos referentes aos casos clínicos apresentados semanalmente na Reunião Anatomoclínica da Disciplina de Patologia Bucal da Faculdade de Odontologia da Universidade de São Paulo. Essas imagens foram digitalizadas utilizando-se ou "scanner" de mesa (HP Scanjet 4C/T) conectado a microcomputador Pentium HP Pavilion, $200 \mathrm{MHz}$, ou sistema de digitalização de diapositivos SprintScan 35 (Polaroid®), também conectado a computador similar. Peças macroscópicas foram digitalizadas por intermédio de máquina fotográfica digital Mavica MVC-FD7 (Sony®), quando necessário, aproveitando-se o momento de processamento da peça no Serviço de Patologia Cirúrgica da Disciplina de Patologia Bucal da FOUSP. Imagens microscópicas foram digitalizadas utilizando-se câmera CCD JVC acoplada ao microscópio Laborlux (Leitz $\left.{ }^{\circledR}\right)$ e conectada a microcomputador Pentium HP Pavilion, 200MHz, com placa de aquisição Captivator. As lâminas foram coletadas do arquivo do Serviço de Patologia Cirúrgica da Disciplina de Patologia Bucal da FOUSP. Os "softwares" de aquisição foram o ImageLab, concebido no Laboratório de Informática Dedicado à Odontologia da Universidade de São Paulo, e o Captura. 
Todos os dados referentes ao caso clínico apresentado (sexo, idade e etnia do paciente, procedência e operador da biópsia, tamanho, localização, aspecto clínico e radiográfico, tipo de biópsia e hipótese diagnóstica) foram coletados sob a forma de documento digital. O nome do paciente e sua procedência foram omitidos. Texto e imagem foram, posteriormente, arquivados e classificados segundo nomenclatura da entidade patológica e data de apresentação do caso clínico. Um pequeno texto contendo informações gerais sobre a lesão foi também estruturado, tendo como base as obras de Araújo; Araújo (1984) e de Neville et al. (1998).

Para o banco de dados da Disciplina de Patologia Geral, foram fotografadas, por intermédio da máquina digital citada anteriormente, peças macroscópicas utilizadas como material didático da Disciplina de Patologia Geral da FOUSP. Imagens microscópicas foram digitalizadas da mesma maneira realizada para a Disciplina de Patologia Bucal, utilizando-se lâminas que também compõem o acervo didático da Disciplina de Patologia Geral. O banco de textos foi feito com base na apostila utilizada em sala de aula pelos alunos, a qual é denominada de PatoArteGeral (Novelli et al., 1993). Todos os dados foram arquivados digitalmente tendo com critério o tema do conteúdo programático ao qual se referem.

A Disciplina de Patologia Geral da FOUSP ministra também um curso de introdução à técnica cirúrgica para a graduação, o qual enfatiza, sobretudo, as relações que a patologia estabelece com o ato operatório. Este trabalho visou também a criação do material didático "on line" desse curso, sendo formado um 
banco de dados para ele, composto por imagens ilustrativas de cada passo da técnica, bem como de texto explicativo da atividade prática e textos teóricos envolvendo tópicos ligados diretamente aos procedimentos diagnósticooperatórios, quais sejam Radiologia, Semiologia e Patologia.

Os bancos de dados de imagem foram compostos por arquivos de alta resolução (300 a 600 dpi), guardadas as devidas proporções de qualidade inerentes ao equipamento não-profissional utilizado. As imagens microscópicas foram arquivadas com baixa resolução $(72 \mathrm{dpi})$, devido à limitação da câmera empregada.

\subsection{Processamento das imagens}

Antes de serem compostas nas páginas com formato HTML, as imagens selecionadas do banco foram submetidas a tratamento eletrônico, com o objetivo de se adequarem, ao recurso da Internet, cor, brilho, contraste, enquadramento, resolução, formato e tamanho. Assim, a resolução de 72 dpi e o formato JPEG foram adotados como obrigatórios para a finalização dos elementos gráficos. O editor de imagens foi o Adobe Photoshop 5.0, da Adobe ${ }^{\circledR}$, executado em plataforma PC (microcomputador Pentium HP Pavilion, 200MHz) e sistema operacional Windows $98 \AA$.

Nas imagens pertencentes à Disciplina de Patologia Bucal, foram inseridas diretamente no arquivo da imagem as informações sobre a origem da figura (nome do cirurgião-dentista que cedeu o material e sua procedência), a entidade patológica a que se refere, a localização da mesma e os dizeres 
"FOUSP". Nas imagens clínicas, foram adotados cuidados para preservação da imagem do paciente, fazendo-se o enquadramento, o máximo possível, na lesão e não inserindo fotografias de face.

Os mesmos cuidados foram adotados para as imagens da Disciplina de Patologia Geral, as quais também receberam, por escrito, a nomenclatura do processo patológico e a sua localização, bem como a identificação "FOUSP".

\subsection{Confecção de vídeos digitais}

Pequeno banco de dados de vídeos digitais foi estruturado para aplicação em ambiente Intranet, sendo direcionado para compor o material do curso de introdução à técnica cirúrgica. Os vídeos foram gravados, inicialmente, em formato analógico, tendo como conteúdo cirurgias filmadas pela Disciplina de Cirurgia da FOUSP. Posteriormente, os vídeos foram digitalizados em plataforma PC, utilizando-se o "software” PC $2000 \AA$ e placa de aquisição MPEG (ATI $\left.{ }^{\circledR}\right)$. Os vídeos foram editados por intermédio do "software" Adobe Première, da Adobe ${ }^{\circledR}$, e arquivados em CDROM.

\subsection{Criação dos "sites"}

A criação dos "sites" seguiu os princípios da linguagem HTML (Hypertext Markup Language) traduzida em interface de construção pelo Microsoft FrontPage $2000 ®$, com escrita direta da mesma, quando necessário. O "layout" 
adotado seguiu os princípios de editoração explicitados em O’Dowd (2000); Lynch \& Horton (2000) e Nielsen (2000).

O "site" da Disciplina de Patologia Bucal foi construído adotando-se um "layout" baseado na composição de dois "frames" (quadros):

- Um "frame" fixo contém o "menu" principal, o qual foi dividido em dois itens; no primeiro item, informações gerais sobre a disciplina e cadastro do usuário ou visitante constituem os "hiperlinks" principais; no segundo item, ficaram os "hiperlinks" referentes à reunião anatomoclínica propriamente dita, com índice alfabético das lesões, sistema de busca criado em JavaScript (autoria própria) e índice nosológico, com a busca sendo feita pela nomenclatura do grupo classificatório.

- Um "frame" dinâmico, acessado segundo a navegação pelos "hiperlinks" do "frame" fixo, foi diagramado de forma a combinar o texto e as imagens do caso clínico. As imagens foram disponibilizadas, nesse primeiro nível, sob a forma de ícones, os quais constituem "links" para imagens maiores e autoexplicativas.

Breves formulários, solicitando a hipótese diagnóstica que o usuário faria, bem como seu sobrenome e sua profissão, foram inseridos ao final de cada descrição do caso clínico, cujo envio era opcional e feito por "e-mail". O laudo histopatológico emitido e as imagens macroscópicas e microscópicas, também sob a forma de ícones, mas passíveis de visualização em maior aumento, foram inseridos em outra página. 
Foram criadas páginas individuais para cada caso clínico, as quais estão conectadas entre si por intermédio da construção de uma árvore de "hiperlinks". Nessa árvore, foram previstas conexões intrapáginas, interpáginas e "intersites". Como "links" essenciais para essas conexões, foram considerados a nomenclatura das lesões (todos os nomes das entidades patológicas remetem a textos básicos, já citados) e os seus grupos classificatórios, seguindo-se a estratégia de classificação da Organização Mundial de Saúde, já bem trabalhada em Corrêa (1998).

Em todas as páginas, foram inseridos um logotipo da Disciplina de Patologia Bucal, concebido especialmente para este trabalho, e uma chamada contendo expressa a proibição de reprodução e de cópia.

Para a criação do "site" de Patologia Geral, também foi utilizado o “software" Microsoft FrontPage 2000®, aplicando-se um "layout" composto por um "frame" único. Nesse "frame", foram construídas duas colunas: a da esquerda, de menor espessura, contém imagens e legendas referentes ao texto presente na coluna da direita. As ilustrações, em tamanho visível, constituem "links" para outras figuras, as quais estão contidas em um banco de imagens específico para o tema acessado. Assim, foram construídos pelo menos dois níveis de abordagem: no primeiro nível, todo o conteúdo referente aos itens do programa da Disciplina de Patologia Geral está disponível sob a forma de texto e imagem; o acesso ao banco de imagens leva a um segundo nível de abordagem, opcional ao usuário; nesse segundo nível, estão disponíveis informações mais detalhadas sobre o mesmo tema do primeiro nível, bem como mais ilustrações. 
Um terceiro nível também pode ser acessado a partir do primeiro; ele foi construído a partir de leituras complementares, na qual ficaram explicitadas informações sobre disciplinas afins, como Histologia, Fisiologia, Anatomia e Bioquímica. Animações (GIFs animados) também foram concebidas para a ilustração de alguns temas, utilizando-se o software Flash, da Macromedia®.

A navegação pelas páginas da Patologia Geral pode ser feita por intermédio de um índice geral ou de um sistema de busca (ferramenta obtida de http://www.freefind.com, a qual é de domínio público). Para o banco de imagens, índices pela nomenclatura do processo patológico ou pelo órgão afetado também estão presentes.

Em todas as páginas, foram inseridos um logotipo da Disciplina de Patologia Geral, concebido especialmente para este trabalho, e uma chamada contendo expressa a proibição de reprodução e de cópia.

O material do curso de introdução à técnica cirúrgica também foi estruturado no Microsoft FrontPage 2000®, com um "layout" composto por três "frames": um superior, contendo "links" de acesso a outros "sites", um central, direcionado para conter as páginas dinâmicas, e um inferior, contendo os "links" referentes a cada módulo (ou aula) do curso. Nesse "frame", a mensagem de proibição de reprodução e cópia ficou constantemente visível.

O curso foi dividido em três grandes módulos: no primeiro, o aluno é orientado sobre noções básicas de auto-proteção (noções sobre contaminação, cuidados preventivos contra cortes e perfurações ocasionados pelos instrumentos etc.) e sobre o material a ser utilizado. Nesse módulo, o aluno aprende também 
como confeccionar um campo fenestrado, sendo introduzido já ao manejo da tesoura, da pinça e de outros instrumentais, bem como à técnica de sutura. No segundo módulo, são iniciados os procedimentos de exame da peça a ser submetida à cirurgia (no caso, a porção da coxa do frango, a qual é extremamente didática para o estudo de diferentes tecidos (pele, músculo, cartilagem e osso)). Nesse módulo ainda o aluno é iniciado à técnica de anestesia, depois de incisão (trabalhando com os diferentes planos teciduais) e, por fim, de sutura (confecção e remoção). No terceiro módulo, noções de remoção e embalagem do material contaminado são transmitidas. Nos passos de anestesia, incisão e sutura, o aluno tem acesso a vídeos digitais ilustrando situações reais vividas pela Disciplina de Cirurgia no ambulatório, os quais foram selecionados do banco de vídeos digitais (item 4.3) $)^{1}$

O gerenciamento dos "sites" foi realizado por um servidor vinculado ao Centro de Computação Eletrônica da USP. O sistema de segurança dos "sites" seguiu, por conseguinte, os ditames desse centro. Para controle personalizado deste trabalho, foram inseridos contadores automáticos, com o intuito de se estimar o número de acessos, bem como criados "e-mails" para cada um deles. Vale dizer que a checagem e o arquivamento das mensagens recebidas (dúvidas, cadastro, testes) foram diários uma vez no ar os "sites".

Nos três "sites" foram criados exercícios, a serem respondidos diretamente no computador e enviados via e-mail. No "site" da Patologia Bucal e

\footnotetext{
1 O "site" contém ainda páginas mostrando a aplicação da técnica cirúrgica na remoção de tumores induzidos experimentalmente em ratos. Essas páginas não foram testadas neste trabalho, mas têm sido aplicadas nas aulas presenciais ministradas pela Disciplina de Patologia Geral, em que os alunos manipulam diretamente o tecido tumoral no rato.
} 
no da Patologia Geral, esses exercícios visaram uma orientação de estudo, já que as várias possibilidades de acesso que o hipertexto gera podem acarretar dificuldades de seleção das informações. Esses exercícios foram dissertativos e disponibilizados sob a forma de formulário, com campos para respostas. No "site" de introdução à técnica cirúrgica, os exercícios foram feitos sob a forma de testes de múltipla escolha com resposta automática, tendo como objetivo avaliar o grau de assimilação de cada passo da técnica.

\subsection{Teste dos "sites" e avaliação}

Ao final do $1^{\circ}$ semestre de 2000 , período selecionado para testar os "sites", foi passado um questionário de avaliação desse novo material didático (Questionários A.2 e A.3, Anexo A, págs. 157 e 158), com o objetivo de detectar a porcentagem de alunos que o utilizou como complementação de seus estudos, a freqüência de acesso do mesmo e a opinião pessoal do corpo discente quanto à qualidade do conteúdo.

Durante o curso de Patologia Geral e Bucal da FOUSP, foi solicitada ainda a presença de cinco alunos para exercícios no computador referentes à matéria da aula presencial (teórica e prática) ministrada no dia. Esses alunos acessaram as páginas das disciplinas a partir de cinco computadores localizados no Laboratório de Informática Dedicado à Odontologia (três microcomputadores PCs Pentium HP Pavillion, 200Mhz, e duas estações gráficas O2, Silicon Graphics $\left.{ }^{\circledR}\right)$. A seleção dos alunos foi aleatória, não tendo caráter de obrigatoriedade a participação. Um examinador observava, durante a confecção 
dos exercícios, o comportamento dos alunos diante do computador; uma ficha de orientação dessa observação (Formulário A.5, Anexo A, pág. 160) era preenchida para cada aluno pelo examinador.

Particularmente no "site" da Patologia Bucal, foi analisada também a participação da comunidade odontológica como um todo, a qual foi balizada por intermédio do número de acessos, dos cadastros feitos e das opiniões enviadas por "e-mail".

O teste do "site" de introdução à técnica cirúrgica foi feito no XXV Congresso Universitário Brasileiro de Odontologia (CUBO), sendo colocados à disposição, no Laboratório de Aulas Práticas do Departamento de Estomatologia, 5 microcomputadores contendo o "software" de ensino a distância TopClass® ${ }^{\circledR}$. O conteúdo do "site", idealizado para ser acessado por intermédio dos navegadores mais comuns (Netscape ${ }^{\circledR}$ e Internet Explorer $\left.{ }^{\circledR}\right)$, foi adaptado para esse "software". Foi programada a utilização de um microcomputador para cada dupla de alunos durante os três dias de curso. $\mathrm{O}$ "mouse" e o teclado foram protegidos com filme de PVC, evitando-se o contato direto da luva do operador sobre eles. O curso durou, em média, 4 horas em cada dia, período durante o qual foi feito o monitoramento dos alunos a distância, por intermédio de microcâmeras acopladas na área de trabalho destinada ao aluno. Essas microcâmeras estavam conectadas a um centro de controle, localizado em uma mesa posta à frente da sala. Esse laboratório de aulas práticas já foi palco de várias experiências preliminares com transmissão de informações a distância (Novelli \& Corrêa, 1999) e está equipado com circuito interno de TV e som, 
microcomputador, microscópio e sistema de aquisição digital de imagens, recursos também utilizados durante o curso. O docente responsável pelo curso intervinha nas ações dos alunos somente quando era solicitado ou nos momentos críticos do curso. O objetivo foi fazer uma simulação do que seria um curso a distância envolvendo prática manual.

A obtenção de dados sobre o desempenho dos alunos foi feita por intermédio de um questionário (Questionário A.4, Anexo A, pág. 159) entregue a eles ao final das atividades, bem como pela observação do seu comportamento, o qual foi filmado e registrado em fita SVHS, cuidando-se para não haver a identificação dos alunos, preservando-se sua identidade. 
RESULTADOS

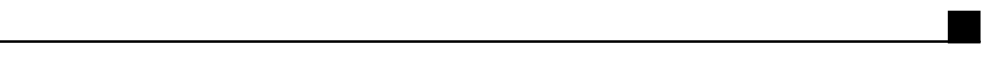




\section{RESULTADOS}

\subsection{Dados obtidos a partir do questionário A.1 (Anexo A, pág. 156)}

Participaram desta pesquisa estudantes de graduação do curso noturno matriculados na Disciplina de Patologia Bucal da FOUSP (59 alunos) e alunos de graduação do curso diurno matriculados na Disciplina de Patologia Geral da FOUSP (76 alunos). O questionário foi respondido por 67 alunos do curso diurno e por 47 alunos do curso noturno.

Em relação ao sexo, o Gráfico 5.1 evidencia que, tanto no curso diurno quanto no noturno, predominam os estudantes do sexo feminino, tendendo a uma distribuição eqüitativa entre homens e mulheres no curso noturno.

GRÁFICO 5.1 - Distribuição dos sexos masculino e feminino nos cursos diurno (67 alunos) e noturno (47 alunos)

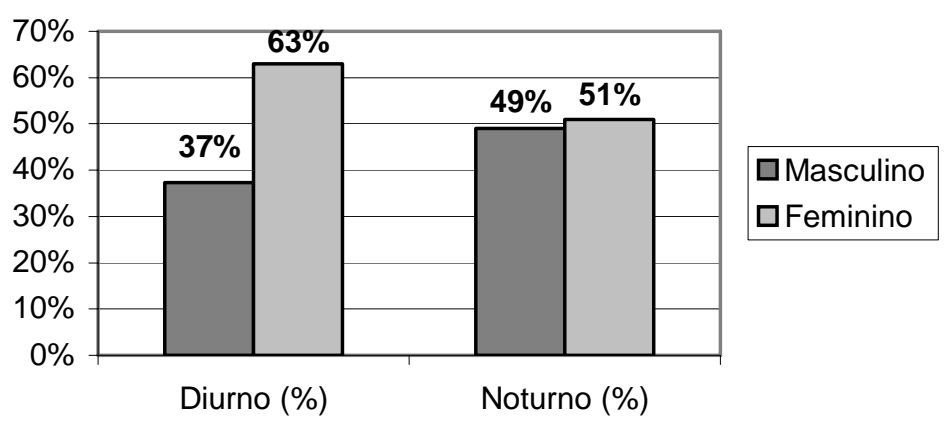

Pelo Gráfico 5.2, nota-se que os alunos, tanto do curso diurno quanto do noturno, situam-se na faixa etária entre 19 e 20 anos de idade. Nota-se também 
que, no curso noturno estão matriculados mais alunos com idade acima dos 21 anos em comparação ao curso diurno.

GRÁFICO 5.2 - Distribuição quanto à faixa etária dos alunos do curso diurno (67 alunos) e noturno (47 alunos)

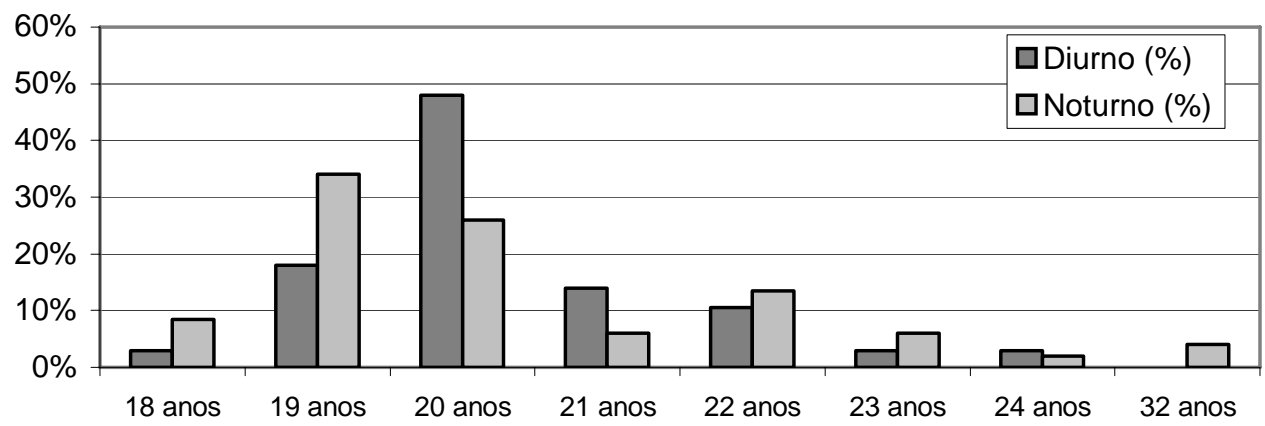

A grande maioria dos alunos possui computador em casa, tanto do curso diurno quanto do noturno (Gráfico 5.3). Contudo, uma porcentagem significativa ainda não possui esse equipamento em sua casa (cerca de $20 \%$ dos alunos nos dois cursos).

GRÁFICO 5.3 - Porcentagem de alunos que possuem ("sim) e não possuem ("não) computador em casa, tanto do curso diurno (67 alunos) quanto do curso noturno (47 alunos)

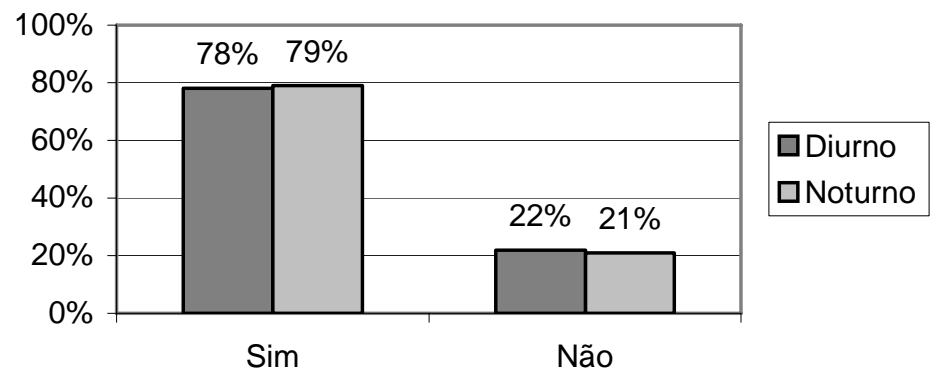


Dos aplicativos listados no questionário A.1 (Anexo A), houve uma distribuição homogênea nos dois cursos (diurno e noturno) em relação à quantidade deles. O Gráfico 5.4 evidencia que os alunos ou não sabem nenhum deles, ou sabem pelo menos dois deles. Nota-se também que, no curso diurno, a população de estudantes é mais heterogênea quanto ao conhecimento dos programas listados, uma vez que se distribui com freqüência bastante semelhante entre 2 a quatro programas. Já no noturno observa-se maior homogeneidade, pois há um pico no conhecimento de nenhum ou de dois aplicativos. Vemos nesse curso, porém, uma freqüência significativa de conhecimento de seis programas listados no questionário (Gráfico 5.4).

GRÁFICO 5.4 - Distribuição (em porcentagem) dos alunos do curso diurno (67 alunos) e do curso noturno (47 alunos) quanto à quantidade de aplicativos conbecidos

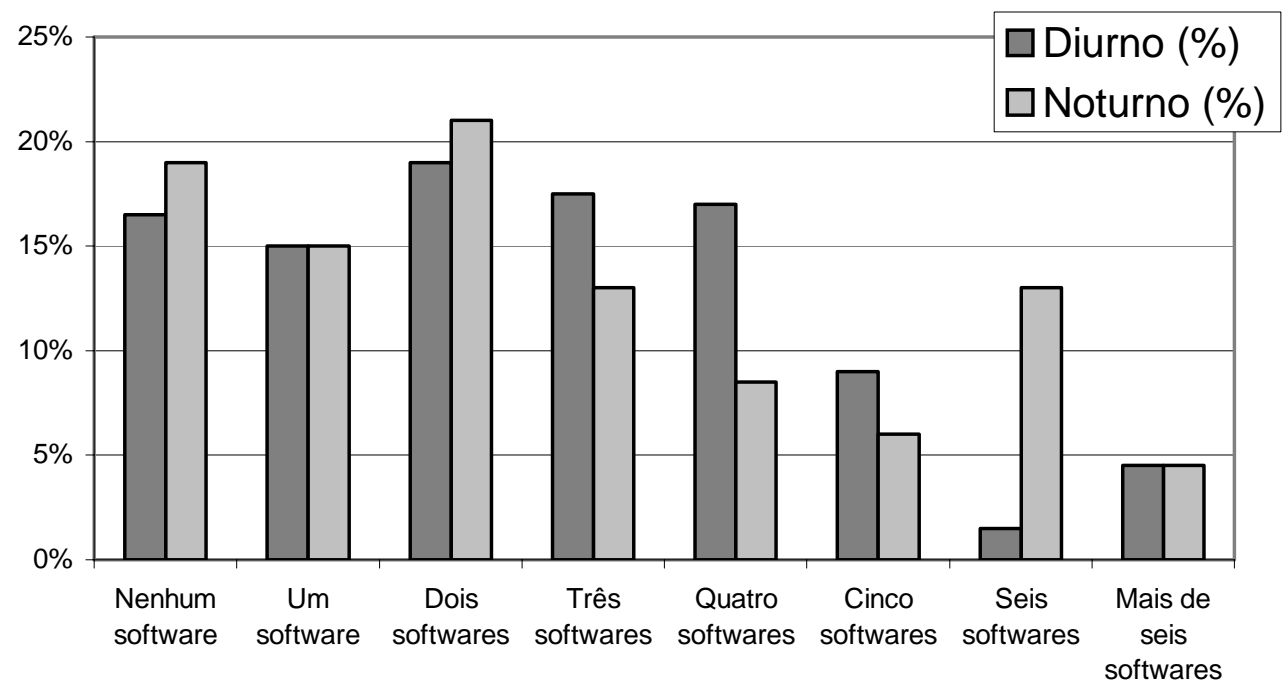


Os programas mais conhecidos são aqueles pertencentes ao pacote Microsoft Office ${ }^{\circledR}$, ou seja, Word, Excel e Power Point (Gráfico 5.5). Uma pequena porcentagem conhece o Corel Draw ${ }^{\circledR}$, um programa para execução de desenhos e ilustrações. Também uma pequena minoria tem conhecimento de programas para edição de imagens (Adobe Photoshop ${ }^{\circledR}$ e Photostyler ${ }^{\circledR}$ ) e menos de 5\% conhecem aplicativos para confecção de páginas para a Internet (editores de HTML Adobe Page Mill®, Front Page ${ }^{\circledR}$ e Hot Dog®). No total, 6 alunos do curso diurno e 4 do noturno conhecem esses editores de HTML (Gráfico 5.5).

GRÁFICO 5.5 - Distribuição (em porcentagem) dos alunos do curso diurno (67 alunos) $e$ do curso noturno (47 alunos) quanto aos aplicativos conhecidos

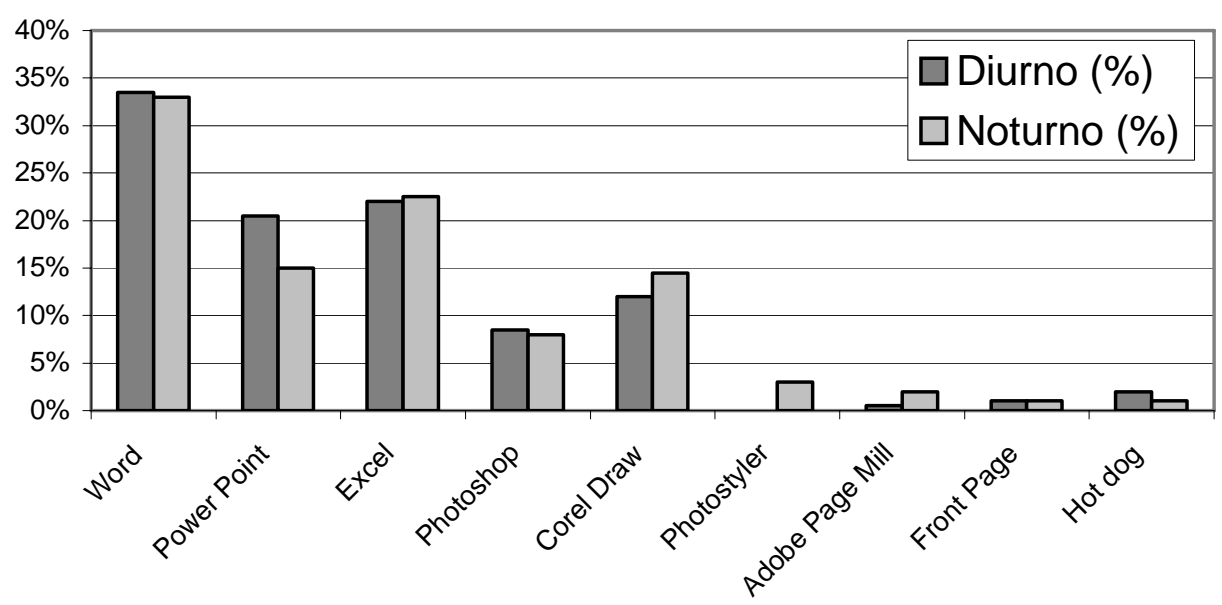


O acesso à Internet é feito pela grande maioria dos alunos (Gráfico 5.6). O fato de não possuir em casa esse veículo de informação é relatado pela maioria como sendo a causa do não-acesso; não saber mexer também constitui uma causa freqüente (Gráfico 5.7).

GRÁFICO 5.6 - Distribuição (em porcentagem) dos alunos que acessam e dos que não acessam a Internet, tanto do curso diurno (67 alunos) quanto do curso noturno (47 alunos).

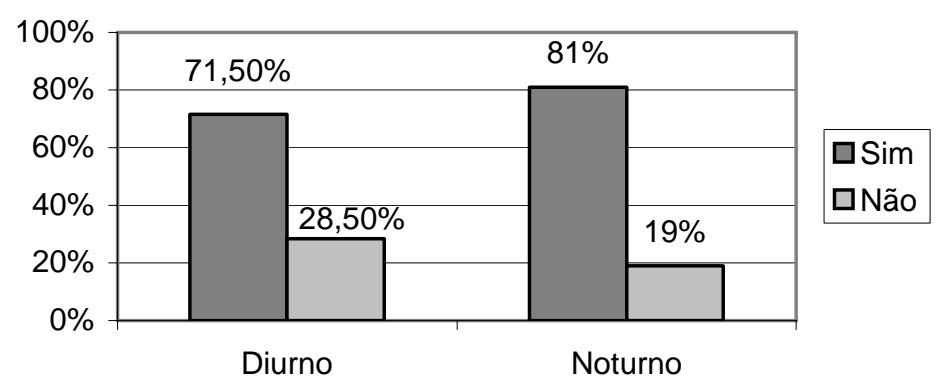

GRÁFICO 5.7 - Motivos que levam os alunos a não acessar a Internet (freqüiência em porcentagem), tanto do curso diurno (67 alunos) quanto do curso noturno (47 alunos)

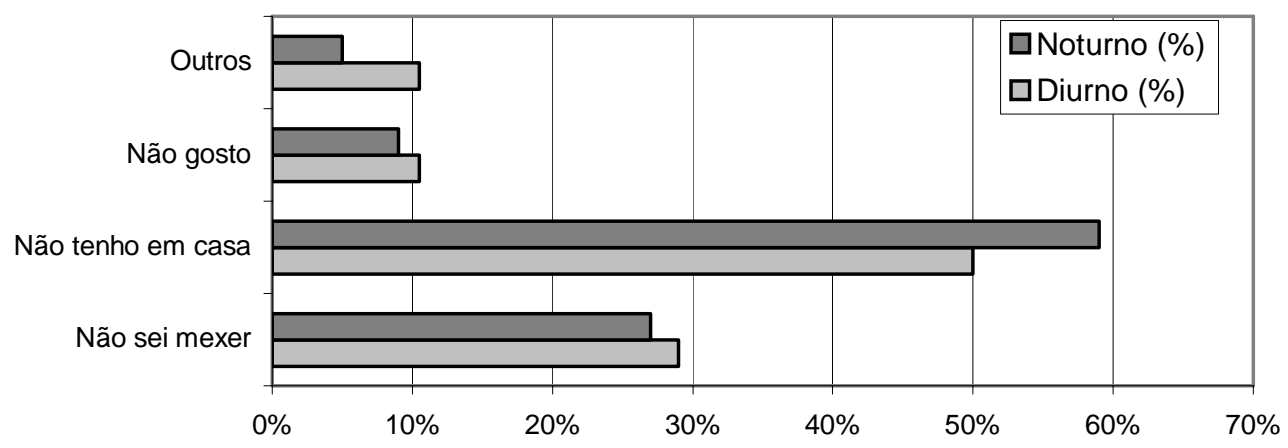

A frequência de acesso à Internet pelos alunos que o fazem gira em torno de uma vez por semana (Gráfico 5.8). Nota-se pelo Gráfico que uma 
porcentagem significativa de alunos do curso diurno acessa a Internet todos os dias. Observa-se também que há uma distribuição heterogênea de freqüência de acesso, ou seja, não há um padrão dessa freqüência em ambos os cursos.

GRÁFICO 5.8 - Distribuição (em porcentagem) da freqüência de acessos à Internet pelos alunos tanto do curso diurno (67 alunos) quanto do curso noturno (47 alunos)

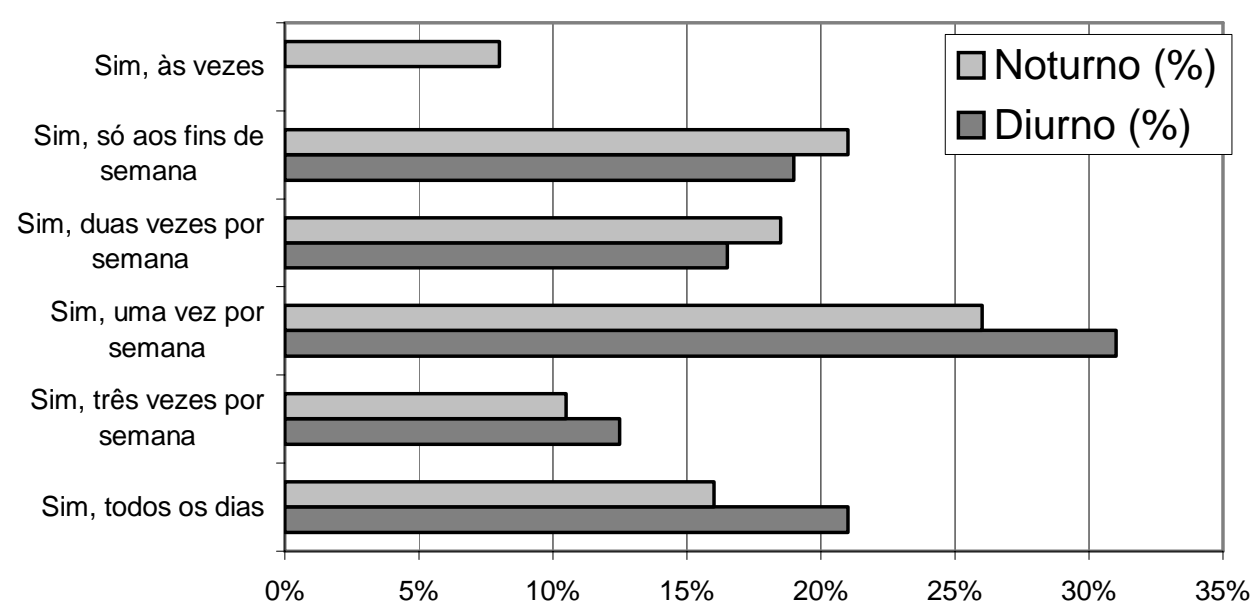

A Internet é utilizada pelos alunos principalmente para consulta de sites em geral e para “e-mail” (Gráfico 5.9). Busca bibliográfica e discussão em grupo também são realizados pelos alunos com porcentagem significativa. O Gráfico 5.10 evidencia principalmente uma distribuição significativa para todas as formas de utilização da Internet enumeradas no questionário A.1 (Anexo A). A maioria dos estudantes tanto do curso diurno quanto do curso noturno assinalaram mais de uma forma de utilização da Internet (Gráfico 5.10). 
GRÁFICO 5.9 - Distribuição (em porcentagem) das formas de utilização da Internet realizada pelos alunos tanto do curso diurno (67 alunos) quanto do curso noturno (47 alunos)

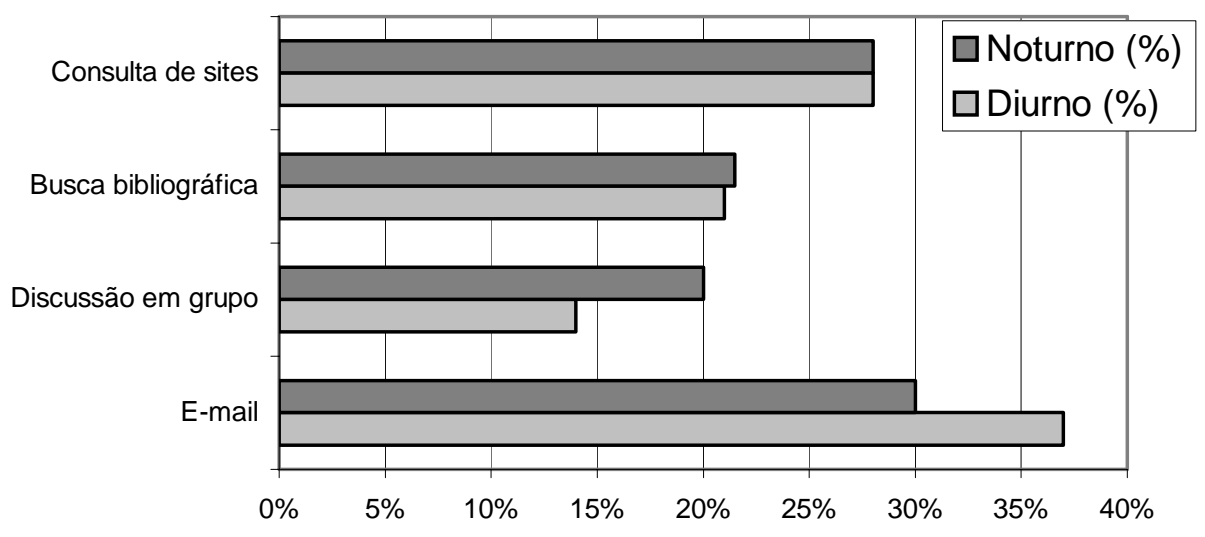

GRÁFICO 5.10 - Distribuição (em porcentagem) da quantidade de formas de utilização da Internet apontadas pelos alunos tando do curso diurno (67 alunos) quanto do curso noturno (47 alunos)

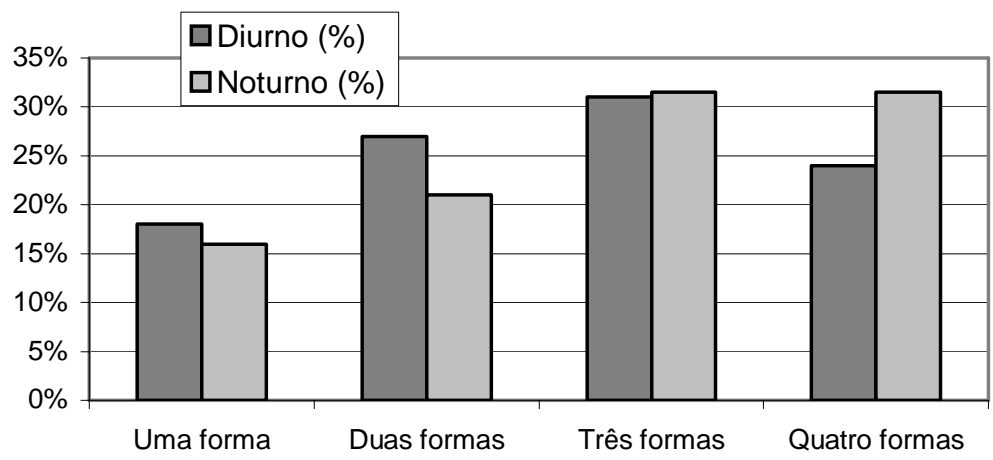

A maioria dos estudantes (tanto do diurno quanto do noturno) costuma consultar, em primeiro lugar, "sites" de entretenimento e, em segundo lugar, “sites" relacionados à Odontologia (Gráfico 5.11). Os estudantes do curso noturno, em termos porcentuais, acessam mais "sites" de Odontologia do que os alunos do curso diurno; estes, por sua vez, acessam mais páginas relacionadas à área médica do que os alunos do curso noturno. 
GRÁFICO 5.11 - Distribuição (em porcentagem) dos tipos de sites consultados pelos alunos tanto do curso diurno (67 alunos) quanto do curso noturno (47 alunos)

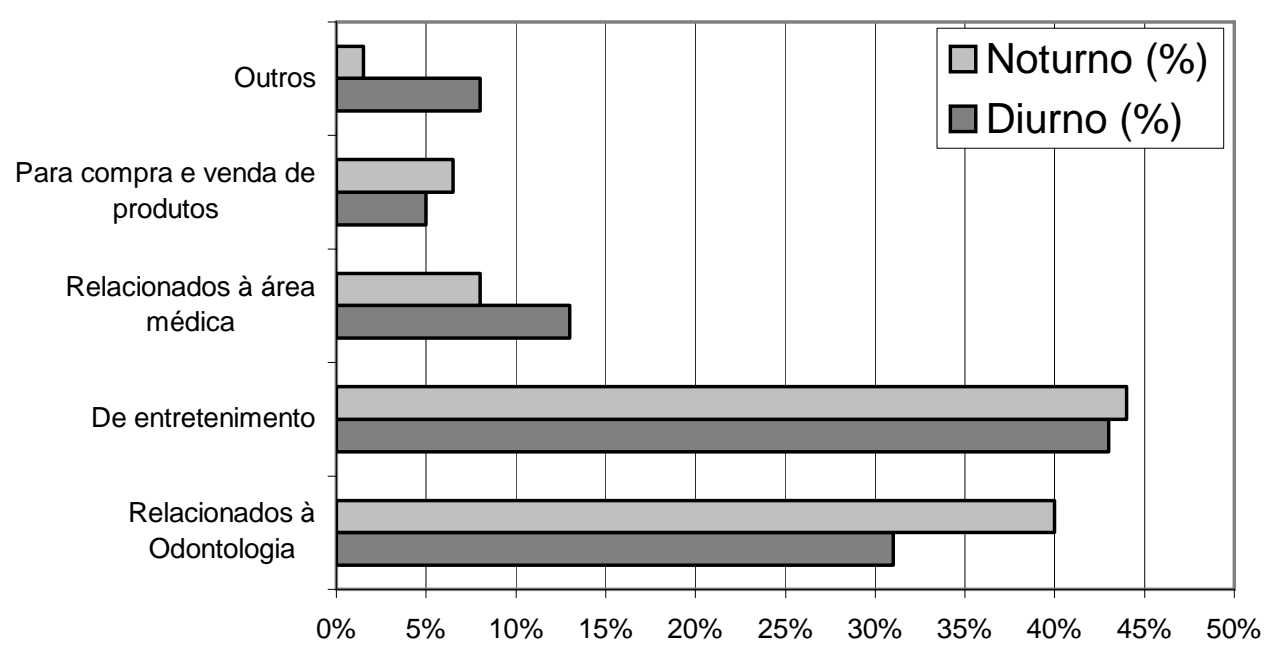

Quanto ao desejo de acessar as matérias do curso de Odontologia pela Internet, o Gráfico 5.12 evidencia que a imensa maioria assim o quer. Vale dizer que 12 alunos do curso diurno e 9 do noturno responderam "sim" sem possuir computador em casa. Um aluno do diurno e um do noturno, ambos sem computador em casa, responderam "não". 
GRÁFICO 5.12 - Distribuição (em porcentagem) do número de alunos, tanto do curso diurno (67 alunos) quanto do curso noturno (47 alunos), que gostaria ou não de acessar as matérias de Odontologia pela Internet

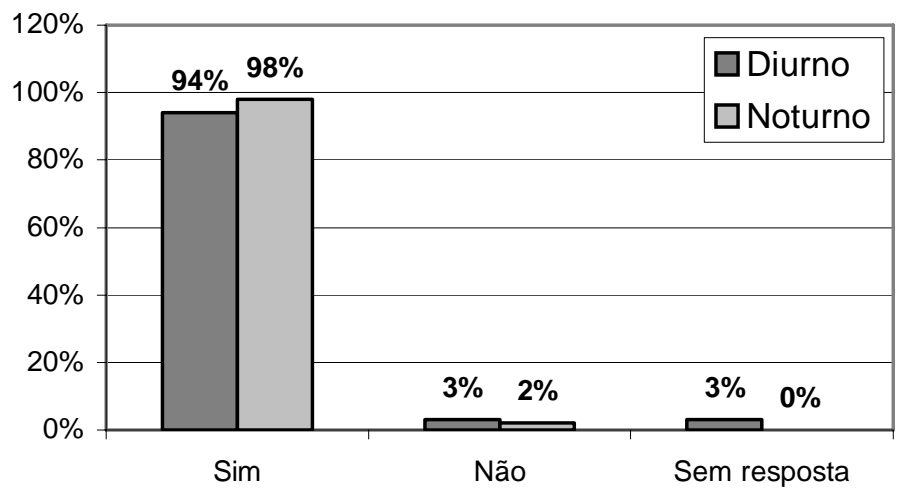

Participaram do curso de introdução à técnica cirúrgica 22 alunos de graduação em Odontologia de diferentes Faculdades de Odontologia do País (Tabela 5.1). Dentre os alunos, 13 eram do sexo feminino e 9 do sexo masculino. As idades variaram bastante, havendo um pico para a idade de 21 anos (Gráfico $5.13)$.

TABELA 5.1 - Distribuição (em número absoluto) dos alunos participantes do curso de introdução à técnica cirúrgica nas diferentes instituições de ensino de Odontologia do País

\begin{tabular}{|l|c|l|c|}
\hline \multicolumn{1}{|c|}{ Instituição } & Número & Instituição & Número \\
\hline Camilo Castelo Branco & 1 & UNIBAN & 1 \\
\hline FOUSP & 5 & Unicastelo & 1 \\
\hline Metodista & 1 & Unicid & 4 \\
\hline PUCCamp & 2 & UNIP & 1 \\
\hline Santa Cecília & 2 & UNISA & 1 \\
\hline UFGoiás & 1 & UNIVALI & 2 \\
\hline
\end{tabular}


GRÁFICO 5.13 - Distribuição (em número absoluto) quanto à idade dos estudantes do curso de introdução à técnica cirúrgica

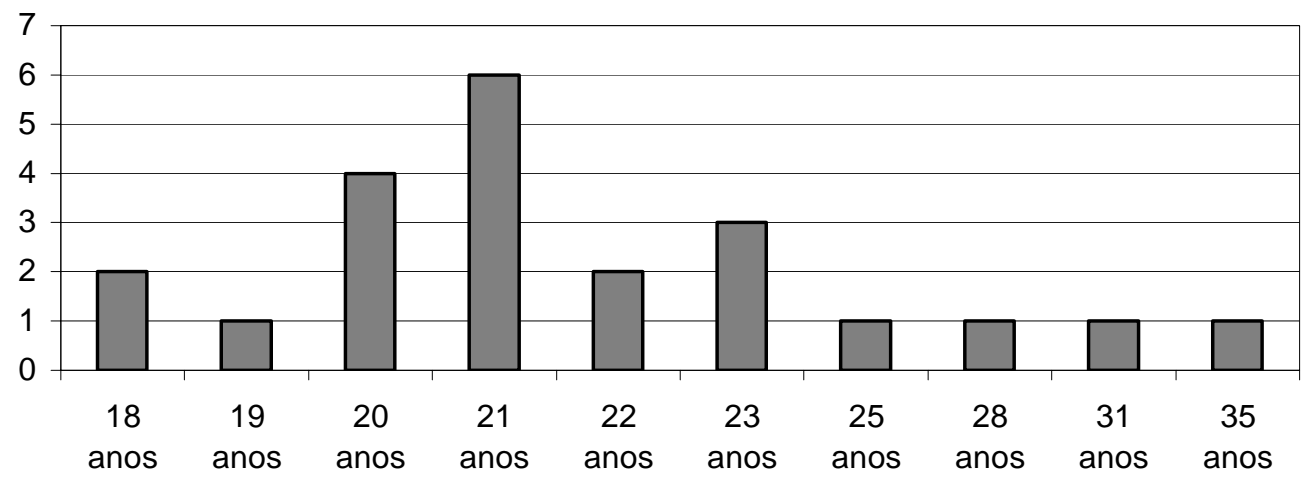

\subsection{Banco de imagens e de textos}

\subsubsection{Patologia Bucal}

O banco de dados estruturado para o "site" de Patologia Bucal foi composto por imagens estáticas e por textos (anotações realizadas durante a Reunião Anatomoclínica e redações feitas por nós baseadas em livros-textos e artigos científicos). O período de formação do banco foi de agosto de 1998 a junho de 2000.

A Tabela 5.2 apresenta o número de casos armazenados e sua distribuição entre os diferentes grupos de patologias. 
TABELA 5.2 - Banco de casos clínicos estruturado para o "site" da Disciplina de Patologia Bucal: quantidade de casos e distribuição entre os grupos de patologias

\begin{tabular}{|l|c|}
\hline GRUPO CLASSIFICATÓRIO DE PATOLOGIAS & N $^{\circ}$ de casos \\
\hline Patologias de glândula salivar & 14 \\
\hline Tumores odontogênicos & 21 \\
\hline Tecidos com características de normalidade & 1 \\
\hline Neoplasias malignas epiteliais & 8 \\
\hline Cistos do sistema estomatognático & 26 \\
\hline Patologias da ATM e do seio maxilar & 3 \\
\hline Patologias ósseas e cartilaginosas & 20 \\
\hline Neoplasias de tecidos moles & 16 \\
\hline Processos reativos (de natureza não-tumoral) & 2 \\
\hline Distúrbios de desenvolvimento & 5 \\
\hline Distúrbios do sistema retículo-histiocitário & 3 \\
\hline Lesões infecciosas & 3 \\
\hline TOTAL & $\mathbf{1 2 2}$ \\
\hline
\end{tabular}

Foram armazenados 122 casos clínicos, todos eles devidamente registrados em relação às características da lesão e do paciente, as quais foram relatadas durante a apresentação na Reunião Anatomoclínica e descritas na ficha de solicitação de exame histológico. $\mathrm{Na}$ Tabela 5.2, nota-se que a grande maioria dos grupos classificatórios contém mais de três casos representativos. Isso indica que o banco de dados formado para este trabalho é qualitativamente diversificado no tocante à abrangência do tema "Patologia Bucal". Boa parte dessas lesões são consideradas raras do ponto de vista casuístico ou possuem características nãocomuns, dignas de discussão. O Anexo B (Tabela B.1, pág. 162) contém a lista de entidades patológicas referentes a cada um desses grupos classificatórios e a sua respectiva quantidade de casos clínicos armazenada.

O total de imagens digitalizadas e a sua natureza compõem a Tabela 5.3. Nota-se que a maioria das imagens são histológicas, vindo em seguida as 
radiográficas/tomográficas e, por fim, as imagens intra e extrabucais. A predominância de histológicos dá-se em função da necessidade de registro de mais de um campo da lâmina (pelo menos dois, portanto, duas imagens) para caracterizar a lesão. Algumas dessas imagens foram obtidas a partir de "slides"; a maioria foi digitalizada diretamente da lâmina. Vale dizer que alguns casos ainda não possuem imagens histológicas, pois optou-se, durante algumas fases do trabalho, em digitalizar as lâminas no momento de confecção do HTML1, fase em que havia o tratamento das imagens.

TABELA 5.3 - Natureza e quantidade de imagens digitalizadas do banco de imagens estruturado para o "site" da Patologia Bucal

\begin{tabular}{|l|c|}
\hline \multicolumn{1}{|c|}{ NATUREZA DA IMAGEM } & QUANTIDADE \\
\hline Intra e extrabucais & 173 \\
\hline Radiográficas/Tomográficas & 222 \\
\hline Histológicas & 257 \\
\hline Macroscópicas & 34 \\
\hline TOTAL & $\mathbf{6 8 6}$ \\
\hline
\end{tabular}

Para o banco de textos da Patologia Bucal, foram criados 70 textos referentes às lesões diagnosticadas nos casos clínicos (Tabela B.2, Anexo B, pág.164).

Foram digitadas também informações referentes a 30 casos já registrados, para iniciar o núcleo de produção do "site"2.

\footnotetext{
${ }^{1}$ Essa opção deu-se principalmente em função do equipamento: em muitas ocasiões, o microscópio com a câmera digitalizadora estava ocupado em outros projetos, não sendo possível o registro da imagem da lâmina concomitantemente às demais imagens do caso. Além disso, em termos técnicos, o tempo de aquisição de imagens a partir da lâmina é redobrado em relação à digitalização de fotos e radiografias, pois requer maior cuidado quanto à escolha da região a ser digitalizada e à qualidade da imagem.

2 Optou-se depois em digitar diretamente no HTML as informações dos casos clínicos, agilizando o processo de criação, uma vez que a conversão do arquivo em Microsoft Word ${ }^{\circledR}$ para HTML constituía mais um passo na produção, o qual poderia ser evitado sem perda da informação.
} 


\subsubsection{Patologia Geral}

O banco de dados estruturado para o "site" da Patologia Geral foi composto por textos e imagens, tanto estáticas quanto em movimento. $\mathrm{O}$ período de formação desse banco foi de junho de 1998 a junho de 2000.

A Tabela 5.4 apresenta a quantidade de imagens que compõem o banco de dados da Patologia Geral segundo os itens temáticos do programa da disciplina.

TABELA 5.4 - Quantidade de imagens digitalizadas que compõem o banco de imagens para cada um dos itens temáticos estruturado para o "site" da Patologia Geral

\begin{tabular}{|c|c|}
\hline ITEM TEMÁTICO & $\mathrm{N}^{\circ}$ DE IMAGENS \\
\hline Introdução & 2 \\
\hline História da patologia & 4 \\
\hline Conceito de saúde e doença & 2 \\
\hline Tipos de agressão & 5 \\
\hline Degenerações e infiltrações & 54 \\
\hline Calcificações patológicas & 15 \\
\hline Pigmentações patológicas & 28 \\
\hline Alterações circulatórias & 56 \\
\hline Morte celular e necrose & 9 \\
\hline Inflamação & 73 \\
\hline Reparação & 18 \\
\hline Alterações de crescimento e diferenciação & 37 \\
\hline Neoplasias & 41 \\
\hline Tecidos normais & 26 \\
\hline TOTAL & 370 \\
\hline
\end{tabular}

O banco de imagens da Patologia Geral caracteriza-se por ser composto por um conteúdo dinâmico em termos de possibilidades de uso e veiculação em hipertextos. Assim, uma imagem que se enquadra no item "Inflamação" é potencialmente vinculável em qualquer um dos outros itens elencados. A 
distribuição das imagens nesses itens, portanto, não é fixa, sendo adotada aqui somente como estratégia de apresentação dos dados.

Todos os itens do programa de Patologia Geral da FOUSP foram incluídos como chaves classificatórias para a formação do banco, estando todos eles alimentados com imagens. Isso indica que há um grande potencial de cruzamento de informações. O registro dessas imagens procurou atender a todos os subitens e classificações adotadas nos itens, de modo a garantir um acervo digital que abarcasse inteiramente todos os tópicos da disciplina.

Semelhantemente ao banco da Patologia Bucal, o da Patologia Geral foi composto principalmente por imagens histológicas (Tabela 5.5). Foram incluídos também alguns casos clínicos de Odontologia e de Medicina que retratassem didaticamente o processo patológico geral abordado. Os esquemas didáticos ilustrações gráficas criadas no computador para representar os passos de um processo, de uma reação ou de uma cadeia, ações de uma célula etc.- e os GIFs animados — imagens em movimento e animações — foram escassos, dada a complexidade técnica de execução nessa fase do trabalho.

TABELA 5.5 - Natureza e quantidade de imagens digitalizadas do banco de imagens estruturado para o "site" da Patologia Geral

\begin{tabular}{|l|c|}
\hline \multicolumn{1}{|c|}{ NATUREZA DA IMAGEM } & QUANTIDADE \\
\hline Histológicas & 214 \\
\hline Macroscópicas & 103 \\
\hline Imagens intra e extrabucais, de membros, radiografias etc. & 37 \\
\hline Esquemas didáticos & 9 \\
\hline GIFs animados & 7 \\
\hline TOTAL & $\mathbf{3 7 0}$ \\
\hline
\end{tabular}


Na Tabela B.3 do Anexo B (pág. 165) encontra-se a distribuição da natureza das imagens do banco da Patologia Geral em relação ao item temático abordado.

O banco de textos estruturado para o "site" de Patologia Geral foi composto por 37 textos complementares redigidos por nós, os quais remetem a temas básicos e a disciplinas correlatas à Patologia Geral, quais sejam Histologia, Fisiologia, Bioquímica, Anatomia etc. Seus títulos e o item temático a que se referem estão listados na Tabela B.4 do Anexo B (pág. 165). O texto-base obtido a partir da Apostila de Patologia Geral (Novelli et al., 1996) foi atualizado em todos os seus capítulos, tomando-se como referência obras mais recentes, para compor também o banco de textos. As informações da apostila e de GuidugliNeto (1997) foram homogeneizadas, ou seja, procurou-se esclarecer as contradições entre ambos e adotar as mesmas classificações, uma vez que ambas as obras são referências para a graduação em Odontologia da USP.

\subsubsection{Curso de introdução à técnica cirúrgica}

O banco de imagens do curso de introdução à técnica cirúrgica foi composto por 170 imagens referentes a cada um dos passos do curso, ou seja, com informações sobre o material e sobre os passos da técnica. Os textos foram criados concomitantemente à confecção das páginas em HTML, não sendo previamente armazenados sob a forma de banco de dados. 


\subsection{Processamento das imagens}

Para os três "sites", foram processadas somente as imagens previamente selecionadas do banco para compor as páginas em HTML. Assim, para a Patologia Bucal, foram tratadas 288 imagens (intra e extrabucais, radiográficas / tomográficas, histológicas e macroscópicas); para a Patologia Geral, 295 imagens (intra e extrabucais, histológicas, macroscópicas e esquemas didáticos); e para o curso de introdução à técnica cirúrgica, 97 imagens (dos passos da técnica, radiográficas etc.).

\subsection{Confecção dos "sites"}

Os "sites" produzidos encontram-se no CD-ROM anexo (Apêndice) ou nos seguintes endereços:

- Patologia Bucal: http://www.usp.br/fo/estomato/patobucal

- Patologia Geral: http://www.usp.br/fo/lido/patoartegeral

- Curso de introdução à técnica cirúrgica: http://www.usp.br/fo/lido/acs

Para a Patologia Bucal, foram confeccionadas 387 páginas em HTML; para a Patologia Geral, 261 páginas; e para o curso de introdução à técnica cirúrgica, 90 páginas.

No "site" da Patologia Geral e no da Patologia Bucal, constam alguns pequenos "scripts" em JavaScript, para promover maior interatividade, principalmente nos exercícios direcionados ao aluno de graduação. Esses "scripts" promovem a abertura secundária de janelas no navegador, o direcionamento de páginas em sistema de busca (para a Patologia Bucal) e a 
substituição de imagens por outras quando há acionamento do botão do "mouse".

A Tabela 5.6 contém um resumo dos principais componentes do "site" da Patologia Bucal. O mesmo se verifica nas Tabelas 5.7 e 5.8, respectivamente para os "sites” da Patologia Geral e para o curso de introdução à técnica cirúrgica.

TABELA 5.6 - Principais componentes do "site" da Patologia Bucal (quantidade e tamanho dos arquivos em kb)

\begin{tabular}{|l|c|c|}
\hline COMPONENTE & QUANTIDADE (KB) & DESCRIÇÃO \\
\hline Total de arquivos & $940(22608 \mathrm{~kb})$ & Todos os arquivos que compõem o site \\
\hline Figuras & $560(21469 \mathrm{~kb})$ & Arquivos de figuras (JPEG e GIF) \\
\hline Hiperlinks & 2309 & Todos os hiperlinks do "site" \\
\hline Hiperlinks externos & 425 & Hiperlinks com destino a arquivos externos ao "site" \\
\hline Hiperlinks internos & 1884 & Hiperlinks com destino a arquivos internos ao "site" \\
\hline
\end{tabular}

Dados obtidos a partir do "software" Microsoft FrontPage ${ }^{\circledR}$.

TABELA 5.7 - Principais componentes do "site" da Patologia Geral (quantidade e tamanho dos arquivos em kb)

\begin{tabular}{|l|c|c|}
\hline COMPONENTE & QUANTIDADE (KB) & DESCRIÇÃO \\
\hline Total de arquivos & $890(22435 \mathrm{~kb})$ & Todos os arquivos que compõem o site \\
\hline Figuras & $623(20881 \mathrm{~kb})$ & Arquivos de figuras (JPEG e GIF) \\
\hline Hiperlinks & 4034 & Todos os hiperlinks do "site" \\
\hline Hiperlinks externos & 727 & Hiperlinks com destino a arquivos externos ao "site" \\
\hline Hiperlinks internos & 3307 & Hiperlinks com destino a arquivos internos ao "site" \\
\hline
\end{tabular}

Dados obtidos a partir do "software" Microsoft FrontPage ${ }^{\circledR}$.

TABELA 5.8 - Principais componentes do "site" do curso de introdução à técnica cirúrgica (quantidade e tamanho dos arquivos em $\mathrm{kb}$ )

\begin{tabular}{|l|c|c|}
\hline COMPONENTE & QUANTIDADE (KB) & DESCRIÇÃO \\
\hline Total de arquivos & $271(39102 \mathrm{~kb})^{\star}$ & Todos os arquivos que compõem o site \\
\hline Figuras & $173(4634 \mathrm{~kb})$ & Arquivos de figuras (JPEG e GIF) \\
\hline Hiperlinks & 417 & Todos os hiperlinks do "site" \\
\hline Hiperlinks externos & 25 & Hiperlinks com destino a arquivos externos ao "site" \\
\hline Hiperlinks internos & 392 & Hiperlinks com destino a arquivos internos ao "site" \\
\hline
\end{tabular}

* Incluindo três vídeos digitais, em formato AVI, os quais estão com cerca de 3,5 Mb cada. Dados obtidos a partir do "software" Microsoft FrontPage ${ }^{\circledR}$. 
A Figura 5.1 ilustra páginas do "site" da Patologia Bucal. Seu "layout" foi composto por dois quadros, com os "hiperlinks" dispostos lateralmente e visíveis durante toda a navegação. Essa composição foi escolhida para conceber uma estrutura do conteúdo semelhante a um arquivo com fichas, nas quais constam casos clínicos.

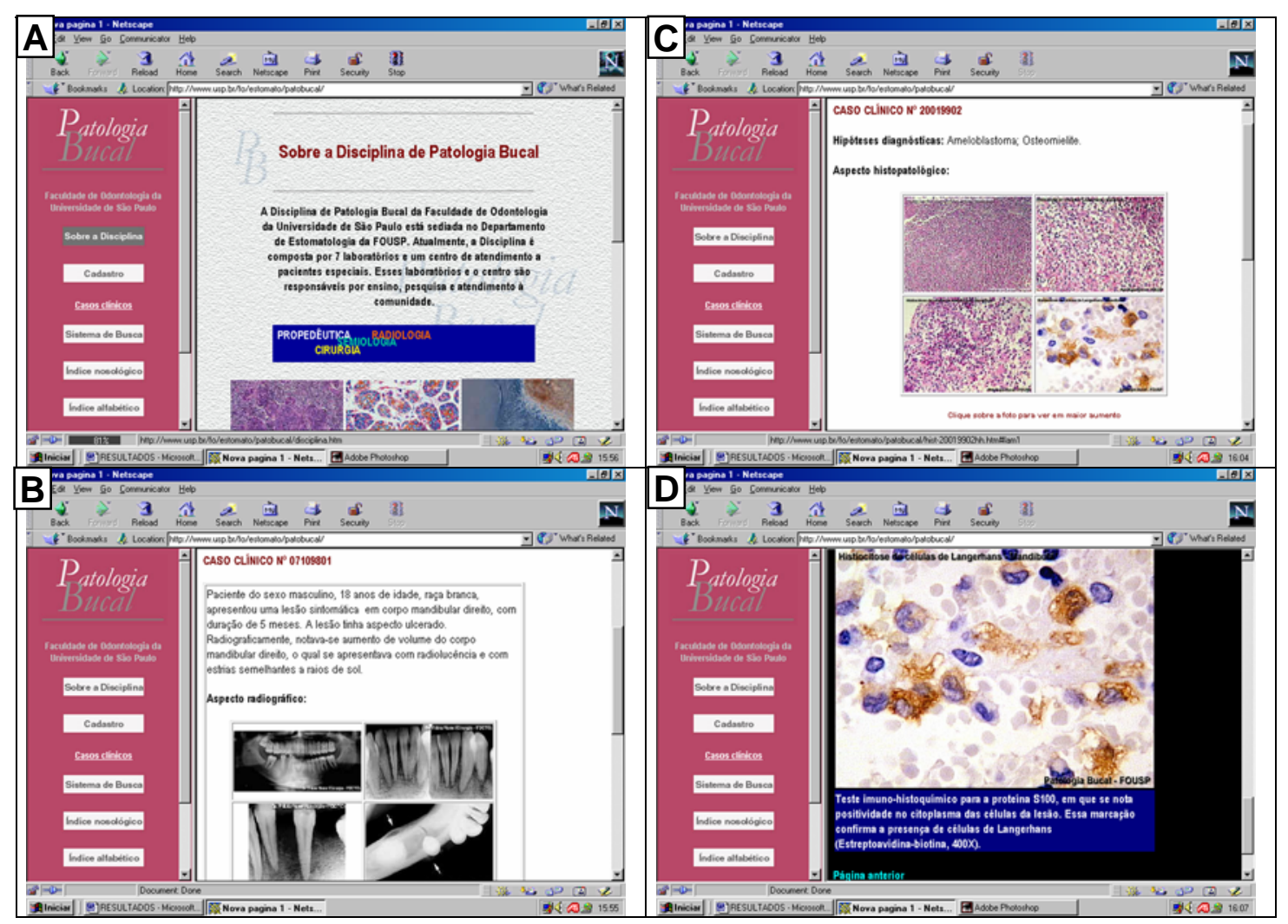

FIGURA 5.1 - "Site" da Patologia Bucal: A: Página de abertura. B: Exemplo de caso clínico com imagens radiográficas. $\boldsymbol{C}$ : Exemplo de como as imagens histológicas são apresentadas, podendo ser visualizadas em maior aumento e com descrições morfológicas detalhadas $(\boldsymbol{D})$. 
Já o "site" da Patologia Geral foi concebido com somente um quadro. Essa composição é bastante semelhante a de um livro tradicional, em que as informações estão dispostas em páginas acessáveis por intermédio de um sumário. A Figura 5.2 mostra algumas páginas do "site".

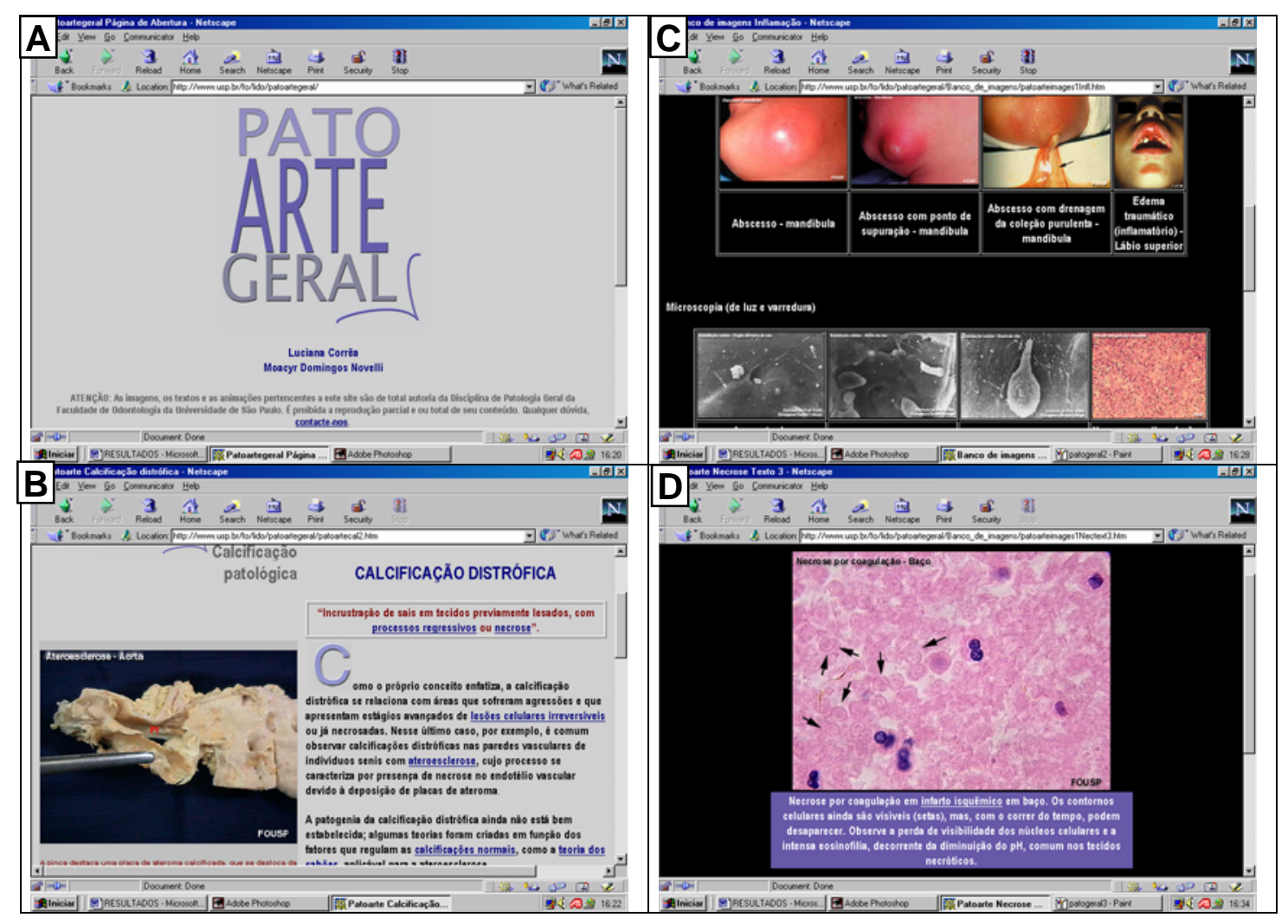

FIGURA 5.2 - "Site" da Patologia Geral. A: Página de abertura do "site". B: Exemplo de tópico desenvolvido; as palavras grifadas e em cor azul são "links"para outras páginas. $\boldsymbol{C}$ : Banco de imagens, o qual é composto por imagens clínicas, macroscópicas e histológicas. $\boldsymbol{D}$ : Exemplo de maior aumento das imagens contidas no banco, bavendo uma descrição detalhada da figura 
Para o "site" do curso de introdução à técnica cirúrgica, foi adotada uma composição com três quadros, pois se tratava de um curso propriamente dito, com passos a serem seguidos que necessitavam do constante contato com os "hiperlinks" relativos ao gerenciamento do "site" (os localizados no quadro superior) e relativos ao manejo do curso (localizados no quadro inferior). A Figura 5.3 mostra algumas páginas desse "site".

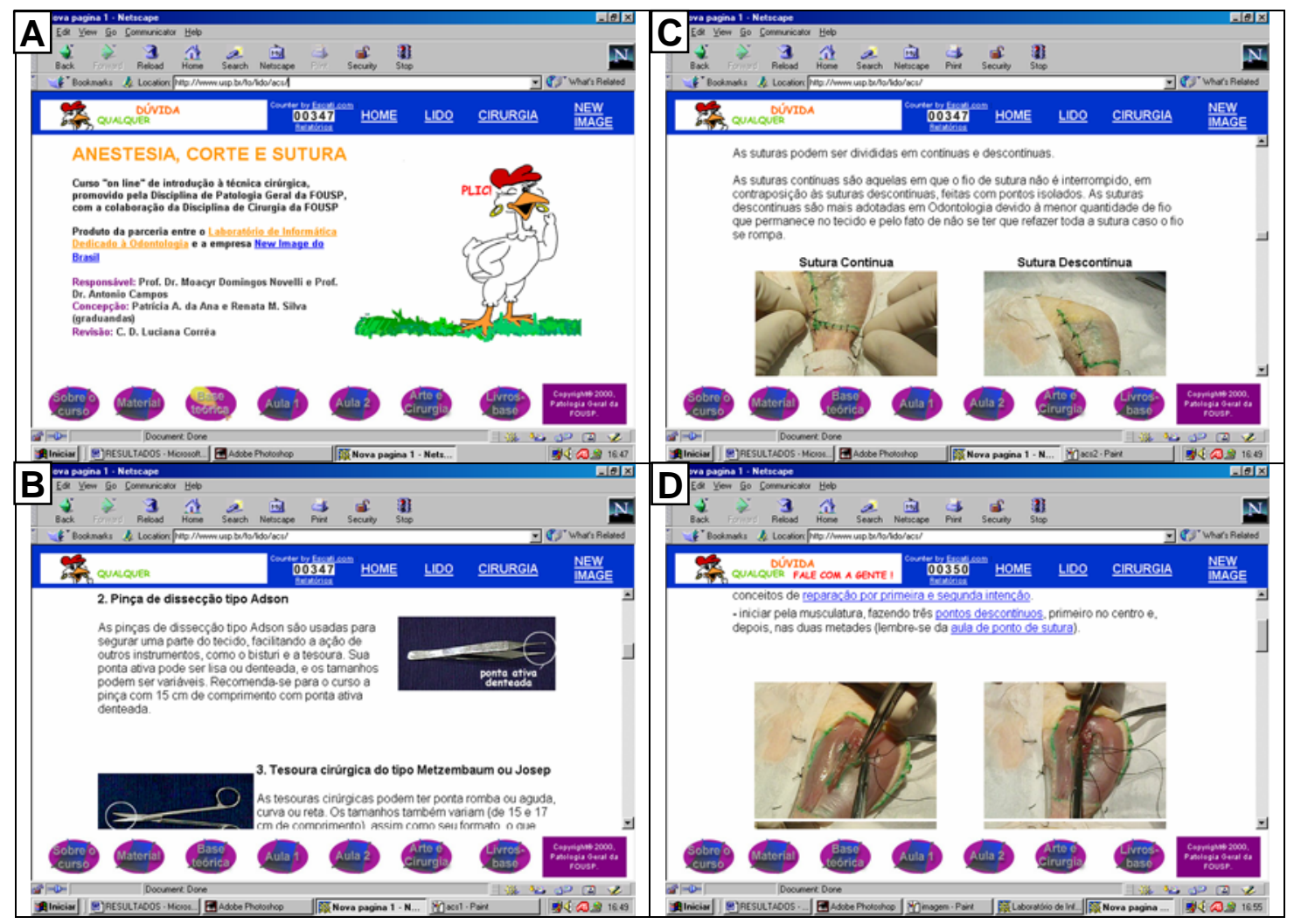

FIGURA 5.3 - "Site" do Curso de introdução à técnica cirúrgica. A: Página de abertura do "site". B: Explicações sobre o material do curso. C: Base teórica, a qual remete para conceitos de cirurgia, patologia e anatomia. D: Última fase do curso, em que os alunos aprendem a suturar os diferentes planos teciduais 


\subsection{Teste dos "sites" e avaliação}

\subsection{1 "Site" da Patologia Bucal}

No período de junho e julho de 2000, foram propostos cinco exercícios de Patologia Bucal, cada qual com três questões cada, com o intuito de transmitir as informações das aulas práticas e articulá-las com as das aulas teóricas. Cada um dos exercícios diz respeito a um grupo de lesões, a saber: distúrbios de desenvolvimento; cistos do sistema estomatognático; tumores odontogênicos; patologias das glândulas salivares; e patologias ósseas. Esses exercícios só foram disponibilizados depois de ter sido ministrada a aula teórica referente a seu tema, simulando a sistemática adotada pela Disciplina de Patologia Bucal da FOUSP, em que, imediatamente após a aula expositiva, há a aula prática sobre o tema desenvolvido na teórica.

A questão 1 desses exercícios promove o contato com o corte histológico em três a quatro aumentos, sendo apontadas as estruturas morfológicas principais a partir da interatividade propiciada por um mapa de imagem. O objetivo dessa questão é fazer o aluno entender a morfologia da patologia por intermédio da comparação com o tecido normal ou com outra patologia do mesmo grupo. A segunda questão é sobre situações clínicas de lesões do mesmo grupo ou de grupos patológicos distintos, fazendo com que o aluno reflita sobre o comportamento e a evolução dessas lesões. Por fim, a questão 3, mais livre, induz o estudante a pesquisar no "site" casos clínicos (pertencentes ao grupo patológico do exercício) que mais lhe agradem, justificando a escolha. A Figura 5.4 ilustra algumas questões desses exercícios. 

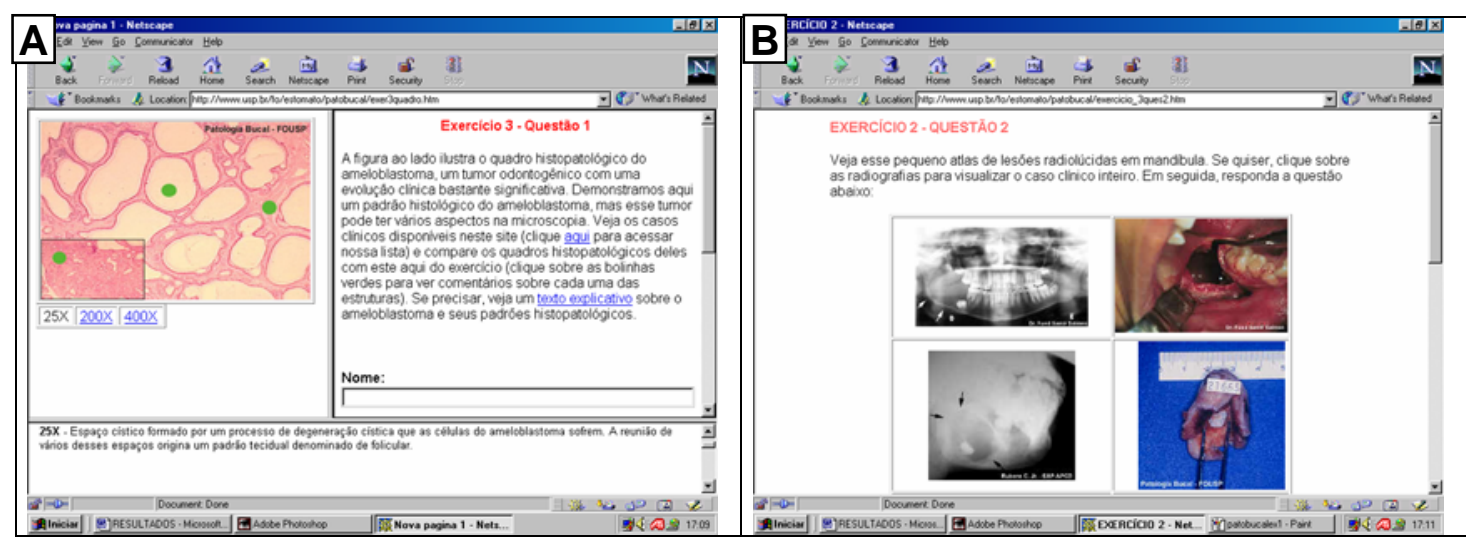

FIGURA 5.4 - Exercícios de Patologia Bucal. A: Questão 1 referente ao exame histológico de lesões significativas para o aluno de graduação. B: Questão 2 em que se relaciona dados de exames complementares diferentes sobre lesões do mesmo grupo classificatório.

Esses exercícios foram aplicados para toda a classe do $3^{\circ}$ ano noturno, sendo obrigatória a confecção destes. Foram recebidos “e-mails” de 55 alunos, ou seja, 93\% da classe fez os exercícios utilizando o computador para envio das respostas. Setenta e três por cento valeu-se do próprio campo do formulário para o envio. Por limitações de acesso aos servidores, não foi possível elaborar um sistema de troca de informações que possibilitasse maior segurança ao remetente no tocante ao recebimento das respostas pelo destinário (por exemplo, deveria ser enviada uma mensagem do servidor dizendo que as informações foram recebidas logo depois que o usuário as submeteu pelo formulário). Diante disso, alguns alunos (27\%) optaram por enviar as respostas por intermédio de seus "emails" pessoais, uma vez que esses sistemas possibilitam o acesso a mensagens de erros, de não-recebimento etc. Três alunos entregaram os exercícios 
pessoalmente, sem enviá-los pelo computador. Um alegou não saber mexer na Internet e os outros dois acharam mais seguro entregá-lo em mãos.

As respostas foram, em geral, bastante longas e elaboradas, denotando uma pesquisa cuidadosa pelo "site". Depoimentos de alunos indicaram que foram gastas no mínimo 3 horas para confecção dos cinco exercícios. Os alunos que utilizaram o Laboratório de Informática Dedicado à Odontologia (LIDO) (4 alunos) para fazer essa atividade gastaram cerca de 7 horas. Os horários de envio dos "e-mails" variaram bastante; a maioria fez os exercícios durante o dia e optou por responder todos de uma só vez (e não conforme os exercícios eram disponibilizados na rede, com intervalo de uma semana entre um e outro).

A Figura 5.5 mostra os alunos acessando o "site" de Patologia Bucal no Laboratório de Informática Dedicado à Odontologia.

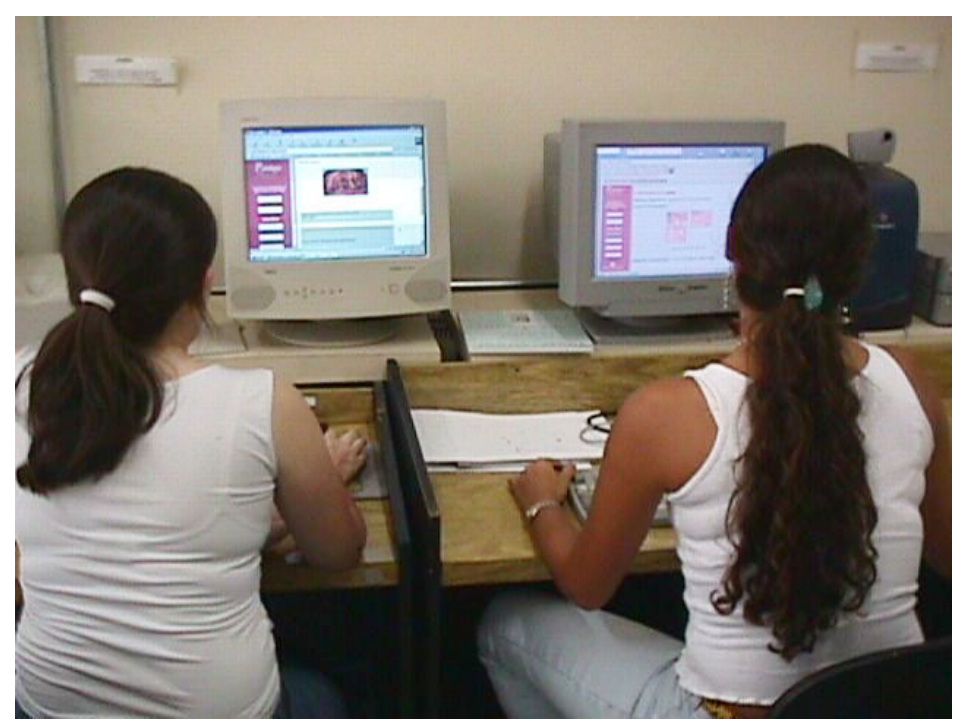

FIGURA 5.5 - Alunas de graduação no momento de confecção dos exercícios de Patologia Bucal

A observação dos alunos que acessaram os exercícios do LIDO evidenciou que os estudantes conseguiram chegar às páginas das perguntas facilmente, seguindo a orientação dada por escrito (a qual foi também entregue a todos da sala). Houve um intervalo de cerca de 1 minuto entre o término da 
leitura da orientação e o acesso da página da lista de exercícios, evidenciando o entendimento imediato da proposta e da linguagem da interface. Alguns alunos tiveram dificuldades de navegação, acreditamos que por problemas de diagramação das páginas e não por desconhecimento da sistemática dos navegadores. Outras dificuldades giraram mais em torno da compreensão das questões, as quais, sendo muito abrangentes em alguns casos, suscitavam dúvidas quanto aos limites das respostas. Uma boa parte dos alunos achou os exercícios trabalhosos, demandando tempo de reflexão e de seleção das informações disponíveis no "site". Vimos também que alguns estudantes optaram por responder certas questões consultando diretamente o caderno ou o livro indicado pela Disciplina. Uma aluna ainda primeiramente acessou o site, anotou as questões, respondeu-as em casa no caderno e, no dia seguinte, digitou-as nos campos disponibilizados nas páginas, enviando-as logo em seguida pelo computador.

Pelo questionário A.2 (pág. 157), o qual foi destinado a coletar as opiniões dos alunos acerca dessa atividade logo após o seu término, notamos que 31 alunos (57\% da sala) fizeram os exercícios em casa. A faculdade foi utilizada por 20 alunos (37\%), os quais valeram-se da biblioteca (1 aluno), da sala pró-aluno ${ }^{3}(9$ alunos) e do LIDO (4 alunos). A Tabela 5.9 mostra essa distribuição.

\footnotetext{
${ }^{3}$ A sala Pró-Aluno faz parte de um programa da Pró-Reitoria de Graduação que visa colocar laboratórios de informática aos alunos de graduação. Na Faculdade de Odontologia, a sala Pró-Aluno contém 15 microcomputadores Pentium $120 \mathrm{MHz}$ disponíveis aos alunos.

(Fonte: http://amandy.redealuno.usp.br/alta/salas/fo.htm )
} 
TABELA 5.9 - Quantidade de alunos em relação ao local de acesso ao "site" da Patologia Bucal

\begin{tabular}{|l|c|c|}
\hline LOCAL DE ACESSO AO “SITE” & \multicolumn{2}{|c|}{ QUANTIDADE DE ALUNOS } \\
\hline na casa de um amigo & 1 & $2 \%$ \\
\hline na faculdade e em casa & 4 & $8 \%$ \\
\hline na biblioteca & 1 & $2 \%$ \\
\hline em casa & 31 & $58 \%$ \\
\hline no LIDO & 3 & $5 \%$ \\
\hline em casa e na sala pró-aluno & 4 & $8 \%$ \\
\hline no trabalho & 1 & $2 \%$ \\
\hline na sala pró-aluno & 3 & $5 \%$ \\
\hline na faculdade & 3 & $2 \%$ \\
\hline na faculdade e na sala pró-aluno & 1 & $5 \%$ \\
\hline no LIDO e na sala pró-aluno & 1 & $2 \%$ \\
\hline resposta inadequada & 1 & $\mathbf{2} \%$ \\
\hline TOTAL & $\mathbf{5 4}$ & $\mathbf{1 0 0} \%$ \\
\hline
\end{tabular}

Pelo questionário, 74\% dos alunos não mudaria nada na apresentação das páginas. Os comentários feitos (Tabela C.1, Anexo C, pág. 168) refletem os principais itens envolvidos com a apresentação de material para WEB: legibilidade ("tipo e tamanho de fonte, para melhor visualização"), composição ("facilitar a leitura dos aspectos histopatológicos - frame na parte inferior - não adequado") e cor (“mesmas cores em todas as páginas”). Um comentário envolveu também a composição e indicou a necessidade do aluno em imprimir o conteúdo do "site": "diminuição da quantidade de frames para facilidade de impressão”. Outros comentários estão disponíveis na Tabela C.1 (pág. 168).

A navegação foi o item mais comentado pelos alunos. Somente 23 alunos (42\%) não mudariam nada. As respostas dadas giraram em torno principalmente da quantidade de "frames", os quais, feitos em demasiado, atrapalhavam a navegação, pois não havia "links" diretos para páginas contendo as listas dos 
exercícios e as questões. Um outro comentário foi a dificuldade que os alunos tiveram em enviar as respostas pela sala pró-aluno, já que nesta os navegadores estavam programados para não permitir o envio de "e-mails" utilizando o sistema de correio eletrônico do Netscape ${ }^{\circledR}$ ou o Outlook Express ${ }^{\circledR}$ (o formulário das questões estava programado para ativar esse sistema).

Um comentário interessante foi a necessidade de maior especificação do "link" para a Patologia Geral, ou seja, o aluno necessita de mais contextualização para transitar de um ambiente para outro. Em geral, no item sobre a navegação, ficou patente a necessidade de uma reformulação da árvore de "links" no tocante a adaptar seu conteúdo e sua abrangência a esse público específico (ver mais comentários na Tabela C.1, pág. 168).

O conteúdo foi satisfatório para 68,5\% da sala (Tabela C.1, pág. 169). Os comentários de necessidade de modificação residem principalmente na complementação com as informações transmitidas nas aulas teóricas, na atualização constante do conteúdo e, principalmente, na adição de mais casos clínicos e de todo o programa de Patologia Bucal (no "site" encontram-se informações de $2 / 3$ do programa).

Quanto às imagens, 69\% dos estudantes disseram que não mudariam nada. Porém, alguns alunos demonstraram necessidade de maior quantidade delas, figuras maiores e com maior nitidez e, sobretudo, imagens interativas (por exemplo, como denota este comentário: "balão de texto ao passar o mouse nas bolinhas"). Algumas fotos não foram compreendidas pelos alunos, principalmente as radiográficas. Essa dificuldade já estava prevista, uma vez que 
esses estudantes não tinham cursado matérias que abordassem essa linguagem, como Radiologia e Semiologia. A inserção de radiografias nesse estágio de aprendizado visou somente um primeiro contato do aluno com essa forma de diagnóstico e o início da reflexão acerca do processo semiológico de identificação de lesões em boca. Um outro comentário fez alusão a casos clínicos sem imagens histopatológicas; essa constatação foi fruto, na verdade, de dificuldade de navegação, pois todos os casos clínicos disponíveis no "site" contêm imagens histopatológicas, salvo um de sialolito, diagnosticado pela radiografia (outros comentários estão na Tabela C.1, pág. 169).

As respostas sobre a necessidade de mudança dos textos do "site" revelaram o desejo de complementação do conteúdo disponível, adicionando mais informações ("mais dados clínicos e de tratamento") e outros autores (“seleção de vários autores e não somente do Neville"). Nesse item os alunos também apontaram as dificuldades encontradas na interpretação das questões dos exercícios ("questões com dificuldade de interpretação"; "questões mais claras"; "perguntas muito longas"). Um dado interessante foi a necessidade de transformação do texto corrido em tópicos ("separação dos textos em tópicos (histologia, clínica etc.)"; "apresentação em forma de tópicos”). Outros comentários estão listados na Tabela C.1 (Anexo C, pág. 169). Os alunos que não mudariam nada quanto aos textos compuseram $67 \%$ da sala.

Em geral, o corpo discente aprovou a iniciativa e demonstrou satisfação em participar deste projeto. Acharam as páginas claras, objetivas e de fácil acesso ao conteúdo. Dentre as expressões positivas coletadas do questionário, destacam- 
se a aprovação dos "links" para a Patologia Geral ("Muito útil o link para a patologia geral"; "acesso a patologia geral muito interessante”) e da qualidade das imagens ("imagens boas"). Outros comentários interessantes selecionados encontram-se na Tabela C.1 (Anexo C, pág. 170). Nesses comentários, novamente os alunos fizeram alusão às dificuldades encontradas de envio das respostas utilizando a sala pró-aluno.

\subsubsection{Impacto do "site" de Patologia Bucal sobre a comunidade odontológica}

O "site" de Patologia Bucal foi submetido ao "mail list" da Sociedade Brasileira de Estomatologia, entidade que representa os estomatologistas de todo o País. Fazem parte dessa lista cerca de 132 pessoas envolvidas com odontologia e ou estomatologia. Por intermédio dessa pequena divulgação, de julho de 2000 até janeiro de 2001, 60 pessoas cadastraram-se no "site" da Patologia Bucal utilizando a sua página de cadastro. As Tabelas 5.10 e 5.11 resumem as características desses usuários no tocante a profissão, especialidade que exercem e estado de origem. 
TABELA 5.10 - Características das pessoas cadastradas no "site" da Patologia Bucal no periodo de julho de 2000 a janeiro de 2001

\begin{tabular}{|l|c|l|c|}
\hline PROFISSÃO & $\mathbf{N}^{\circ}$ & ESPECIALIDADE & $\mathbf{N}^{\mathbf{0}}$ \\
\hline Cirurgião-dentista & 34 & Clínica Geral & 5 \\
\hline Estudantes & 21 & Cancerologia & 1 \\
\hline Professor Universitário & 4 & Cirurgia e Traumatologia & 2 \\
\hline Pós-graduando & 1 & Dentística & 1 \\
\hline Profissional administrativo & 1 & Endodontia & 2 \\
\hline TOTAL & $\mathbf{6 1}$ & Estomatologia & 12 \\
\hline \multirow{3}{*}{} & Patologia Bucal & 11 \\
\cline { 2 - 3 } & Saúde Coletiva & 1 \\
\cline { 2 - 3 } & Periodontia & 1 \\
\cline { 2 - 3 } & Radiologia & 3 \\
\cline { 2 - 3 } & Sem especialidade & 22 \\
\cline { 2 - 3 } & TOTAL & $\mathbf{6 1}$ \\
\cline { 2 - 3 } & &
\end{tabular}

TABELA 5.11 - Estado de origem dos usuários cadastrados no "site" da Patologia Bucal

\begin{tabular}{|l|c|l|c|}
\hline ESTADO DO BRASIL & $\mathbf{N}^{\mathbf{0}}$ & ESTADO DO BRASIL & $\mathbf{N}^{\mathbf{0}}$ \\
\hline Alagoas & 2 & Pernambuco & 4 \\
\hline Bahia & 1 & Paraná & 2 \\
\hline Ceará & 2 & Rio de Janeiro & 8 \\
\hline Distrito Federal & 2 & Rio Grande do Sul & 2 \\
\hline Goiás & 1 & Santa Catarina & 5 \\
\hline Minas Gerais & 3 & Sergipe & 1 \\
\hline Mato Grosso & 2 & São Paulo & 24 \\
\hline Mato Grosso do Sul & 2 & TOTAL & $\mathbf{6 1}$ \\
\hline
\end{tabular}

As páginas de casos clínicos contêm formulários em que se questiona a opinião do usuário quanto ao diagnóstico da lesão. No período de julho de 2000 até janeiro de 2001, 33 opiniões foram enviadas, a maioria por estudantes (63\%). 


\subsection{2 "Site" da Patologia Geral}

No "site" da Patologia Geral, foram criados dois exercícios a serem respondidos diretamente em campos de formulários. As respostas foram enviadas também via "e-mail", sendo todo o procedimento feito pelo computador, sem intermediação de impressos. Os exercícios referem-se a três blocos temáticos da disciplina de Patologia Geral: alterações circulatórias, necrose e inflamação. As questões buscaram relacionar os processos gerais estudados em sala de aula com situações clínicas presentes na cavidade bucal e no cotidiano do consultório dentário. Além disso, foram criadas polêmicas (mediadas por dois personagens caricaturescos, "Mr. Pathos" e "Mr. Moa") entre as visões da anatomopatologia e da patologica clínica acerca do mesmo processo geral, solicitando-se a opinião do aluno sobre essas duas visões. A Figura 5.6 ilustra esses exercícios.

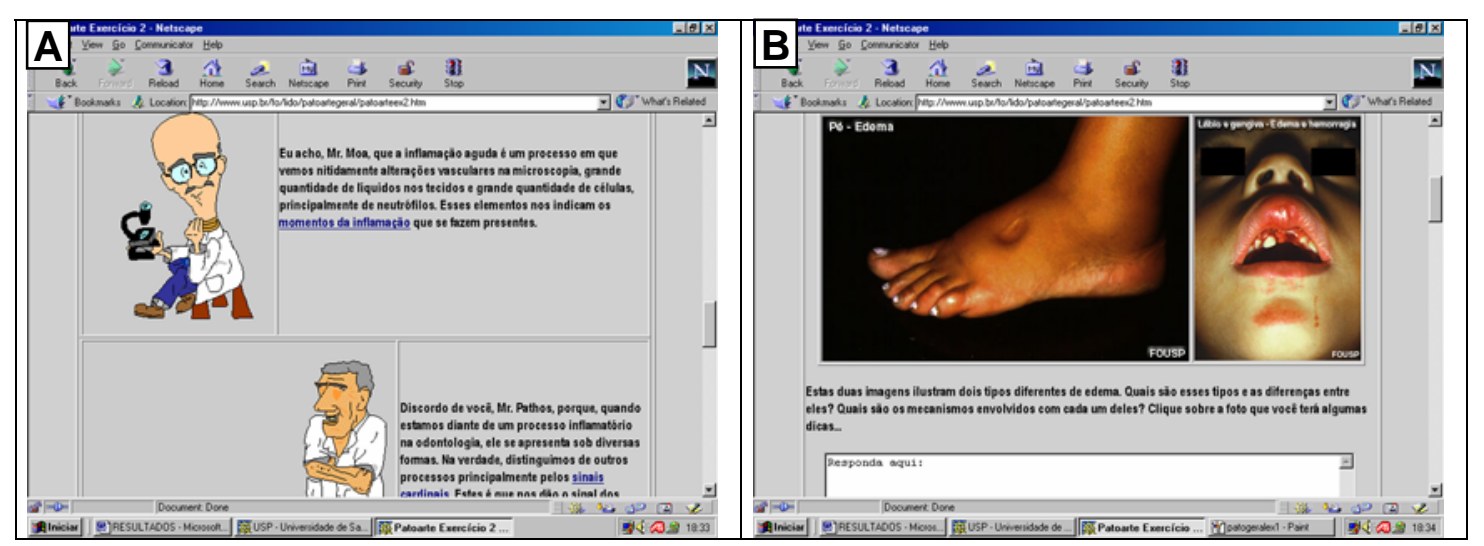

FIGURA 5.6 - Exercícios de Patologia Geral. A: Personagens caricaturescos que se antagonizam e criam polêmicas envolvendo os processos patológicos gerais. $\boldsymbol{B}$ : O confronto entre uma situação clínica de origem sistêmica e uma de origem local específica da área odontológica fazem com que os alunos reflitam sobre a magnitude dos processos gerais 
Participaram da confecção dos exercícios no Laboratório de Informática Dedicado à Odontologia (LIDO) 10 alunos de graduação, os quais estavam cursando a Disciplina de Patologia Geral no período de abril e maio de 2000. A Figura 5.7 mostra um dos momentos da observação dos alunos no LIDO.

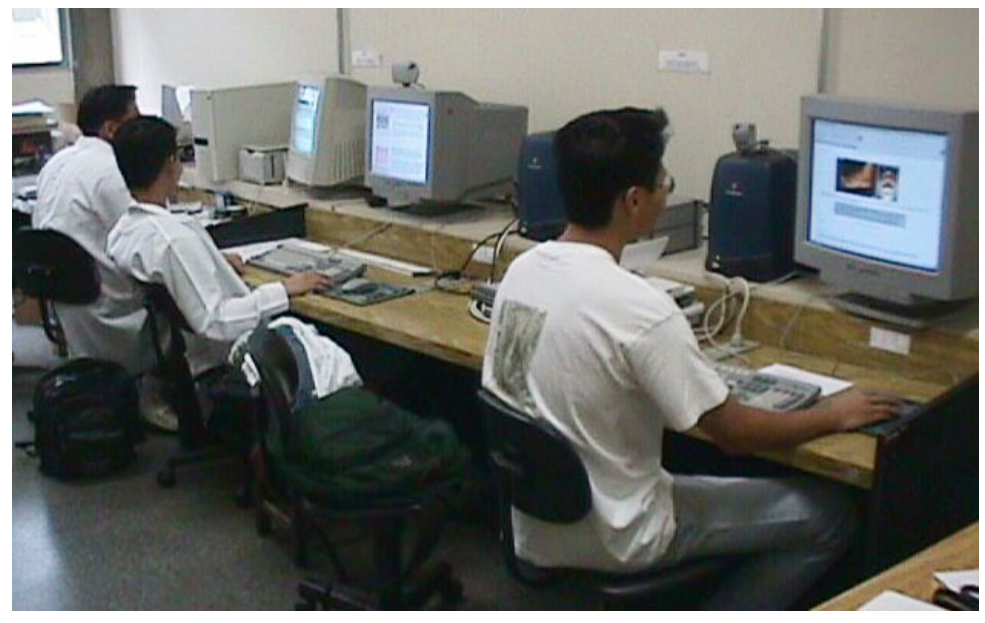

FIGURA 5.7 - Alunos acessando o "site" de Patologia Geral no Laboratório de Informática Dedicado à Odontologia. Estavam disponiveis nessa sala um PC e duas estações Silicon Graphics, as quais foram manipuladas pelos alunos sem constrangimento, mesmo sem conhecer essa plataforma

A partir dessa observação, tal qual no teste do "site"da Patologia Bucal, detectou-se que todos os alunos acessaram facilmente as páginas e revelaram grande facilidade de manejo do computador e do navegador. Facilidade de digitação também foi patente, não constituindo essa atividade um empecilho para a execução do exercício. Verificou-se que alguns alunos consultaram seu caderno de anotações para responder as questões, demorando a perceber que toda a matéria estava disponível no "site". Alguns alunos (30\%) revelaram dificuldades de navegação, pois novas janelas eram abertas a cada "link" presente nas questões, o que levou os estudantes a se perderem, pois não fechavam a janela após a consulta e não sabiam em qual delas estava a questão a ser respondida ${ }^{4}$. Foram poucos os alunos que acessaram a página da Patologia Bucal (cerca de 
20\%); quando o fizeram, detiveram-se muito brevemente na leitura dessas páginas, voltando logo para o "site" da Patologia Geral. Para responder cada questão, detectou-se uma média de 5 páginas acessadas, cuja ordem de acesso variou de aluno para aluno; ou seja, as estratégias de consulta foram diversas. A ordem das questões a serem respondidas também variou.

Como já comentado no "site" da Patologia Bucal, as limitações do sistema de envio das respostas utilizando "e-mail" e formulário (o qual não dispõe de sistema de segurança contra a perda de informações e confirmação de recebimento) fizeram com que $20 \%$ dos alunos perdessem todas as suas respostas no primeiro exercício. Já no segundo exercício, em que cada resposta era enviada assim que terminada (diferentemente do primeiro exercício, em que o aluno submetia todas as respostas juntas só ao final), nenhum aluno perdeu suas respostas. Contudo, ainda assim alguns estudantes tiveram que digitar novamente parte de seu texto por perderem-no durante a navegação de consulta.

Durante o exercício 1, foram detectadas algumas falhas de confecção da interface, tais como abertura de janelas em demasiado e não-visibilidade de campos para resposta em alguns navegadores. Essas falhas foram corrigidas no exercício 2, o qual apresenta uma estrutura de abertura de janelas mais restrita. Os alunos demoraram, em média, 2,5h para fazer o exercício 1 e $2 \mathrm{~h}$ para fazer o exercício 2.

\footnotetext{
${ }^{4}$ Esse problema foi posteriormente corrigido, adotando-se um "script" em JavaScript que fecha a janela automaticamente quando um clique é dado fora desta.
} 
O levantamento das impressões do corpo discente quanto ao "site" foi baseado em setenta questionários (Questionário A.3, Anexo A, pág. 158) respondidos, dos quais 54 (78\%) foram de estudantes que acessaram o "site" e 16 (22\%), de alunos que não acessaram. Desses 54 alunos, 35 (65\%) acessaram de casa e 17 (31\%) utilizaram a estrutura da faculdade (incluindo a sala pró-aluno) para acessar o material (Tabela 5.12).

TABELA 5.12 - Quantidade de alunos em relação ao local de acesso ao "site" da Patologia Geral

\begin{tabular}{|l|c|c|}
\hline LOCAL DE ACESSO AO “SITE" & \multicolumn{2}{|c|}{ QUANTIDADE DE ALUNOS } \\
\hline De casa e na faculdade & 5 & $9 \%$ \\
\hline Em casa & 35 & $65 \%$ \\
\hline Em casa e na pró-aluno & 3 & $6 \%$ \\
\hline Na faculdade & 5 & $9 \%$ \\
\hline Casa de amigo & 2 & $4 \%$ \\
\hline Na pró-aluno & 4 & $7 \%$ \\
\hline TOTAL & $\mathbf{5 4}$ & $\mathbf{1 0 0 \%}$ \\
\hline
\end{tabular}

Na questão 1 desse questionário, referente à apresentação das páginas, 45 (83\%) alunos responderam que não mudariam nada, sendo computados 10 comentários diferentes (Tabela C.2, Anexo C, pág. 171), os quais abrangeram, tal qual o aconteceu na Patologia Bucal, praticamente todos os aspectos envolvidos com interface, a saber: acessibilidade ("modo de acesso mais rápido"), legibilidade ("tipo e tamanho de fonte"), composição ("página muito quebrada"; "logo muito grande") e navegabilidade ("inserção de índice remissivo"). Três comentários revelaram a necessidade de uma estrutura de interface mais adequada para impressão do conteúdo ("numeração das páginas no rodapé"; 
“estrutura de tabelas (dificuldade de impressão)"; "estrutura de imagens e texto, com permissão somente para impressão do texto”).

A questão referente à navegação pelas páginas foi direcionada especificamente para o aspecto de navegabilidade e interatividade do "site". Para 48 alunos (89\%), não seria necessária nenhuma modificação. Foram coletados 7 comentários acerca desse aspecto (Tabela C.2, pág. 171); um deles revela a necessidade de "mais links específicos" e outro, "menos links para facilitar a impressão".

O impacto quanto ao conteúdo foi o mais significativo nesse questionário. Trinta e um alunos (57\%) disseram que não modificariam nada, mas foram registrados 27 comentários nessa questão que revelaram algum grau de insatisfação (Tabela C.2, pág. 171). Foi a pergunta do questionário mais comentada. Necessidades como "conteúdo mais aprofundado", “mais detalhado", "informações complementares e curiosidades sobre a matéria" e "mais exemplos dentro da Odontologia" ficaram patentes. Como um todo, esses comentários revelaram haver um certo descompasso entre as aulas expositivas ministradas durante o curso e as informações disponíveis no "site".

$\mathrm{Na}$ questão envolvendo as imagens, os alunos manifestaram principalmente a necessidade de maior quantidade delas, tanto clínicas quanto macro e microscópicas (Tabela C.2, pág. 172). Quarenta e dois alunos (77\%) disseram que não mudariam nada. O mesmo número de alunos revelou não querer modificar nada quanto aos textos. Os comentários sobre essa última questão coincidiram, em parte, com o do conteúdo, principalmente no tocante à 
necessidade de textos mais aprofundados e diferentes dos da apostila. Vontade de mais textos relacionados a casos clínicos em Odontologia também foi manifestada.

Os comentários positivos do "site" indicaram que os alunos aprovaram a iniciativa, manifestando vontade de que o projeto continue. Uma reclamação foi a atualização constante do "site": os alunos sentiram necessidade de que o conteúdo estivesse disponível antes da prova ("matéria deveria estar a disposição bem antes da prova"), para terem maior tempo para estudar. Essa foi uma falha bastante comum neste projeto: a manutenção constante do "site" em tempo compatível com o ritmo das aulas em presença. Outros comentários interessantes selecionados do questionário encontram-se na Tabela C.2 (Anexo C, pág. 172).

\subsection{3 "Site" do curso de introdução à técnica cirúrgica}

Antes do início desse curso no XXV Congresso Universitário Brasileiro de Odontologia, foi comunicado aos alunos matriculados a existência do "site" e solicitado a eles que o acessassem, para se interarem da proposta. Pelo questionário A.4 (Anexo A, pág. 159), entregue aos estudantes ao término de suas atividades, verificou-se que $46 \%$ deles acessaram as páginas na Internet de suas casas previamente ao início do curso e 50\% não acessaram. Um dos alunos relatou não ter acessado por ter recebido endereço errado.

Para 77\% dos estudantes foi fácil trabalhar com o "site" e realizar a técnica cirúrgica ao mesmo tempo. Pelos depoimentos, verificou-se que essa facilidade foi devida principalmente à seqüência clara dos passos demonstrada no 
“site" (Tabela C.3, pág. 173). O restante do grupo (23\%) teve dificuldades de trabalhar em conjunto com o computador devido a limitações pessoais (ansiedade, falta de habilidade, dificuldade de interpretação das informações etc.) (Tabela C.3, pág. 173).

O questionário A.4 (Anexo A) ainda solicitou aos alunos que atribuíssem valores de 0 a 10 para o papel da televisão, do computador e do professor no aprendizado durante o curso. As médias para cada um desses recursos foi, respectivamente, 8,7, 9,5 e 10,0, ficando evidente o papel secundário da televisão nesse processo.

Cada um desses recursos foi objeto de opiniões por parte dos participantes no questionário. Perguntou-se em quais momentos do curso cada um deles foi importante. Segundo esses depoimentos, a televisão foi importante para os alunos por possibilitar o acesso às informações de forma homogênea, em que todos os estudantes podiam ter contato com a mesma informação. Alguns utilizaram pouco a televisão; outros, em todos os momentos valeram-se dela. A possibilidade de observação dos trabalhos dos demais colegas também foi um dos pontos relatados. Outros comentários encontram-se na Tabela C.4 (pág.174).

Para uma boa parte dos estudantes, o computador foi importante em todos os momentos, pois explicava os passos da técnica. Serviu ainda como fonte de eliminação de dúvidas (mais comentários encontram-se no Anexo C, Tabela C.4, pág. 174).

O papel do professor residiu principalmente como um tirador de dúvidas, sendo solicitado nos momentos de dificuldade ou para sanar as dúvidas não 
resolvidas pelo computador e a televisão. Uma boa parte dos alunos relatou que o professor foi essencial em todos os momentos do curso. Foi importante também para chamar a atenção quanto ao manuseio do instrumental (outros comentários encontram-se no Anexo C, Tabela C.4, pág. 174).

Os pontos positivos do curso, segundo os participantes, dentre outros (Tabela C.5, Anexo C, pág. 175) foram o aprimoramento da técnica cirúrgica, o conhecimento do instrumental e os recursos tecnológicos. Os pontos negativos — quando apontados, pois uma parcela significativa dos estudantes (11 no total) não citou pontos negativos - foram a monotonia do computador (somente um aluno apontou isso) e a falta do professor fazendo a técnica junto com o aluno. Outros pontos negativos encontram-se listados na Tabela C.5 (Anexo C, pág. 175).

As Figuras 5.8 e 5.9 ilustram alguns momentos do curso, em que os alunos executam a técnica cirúrgica seguindo os passos apresentados no "site". 

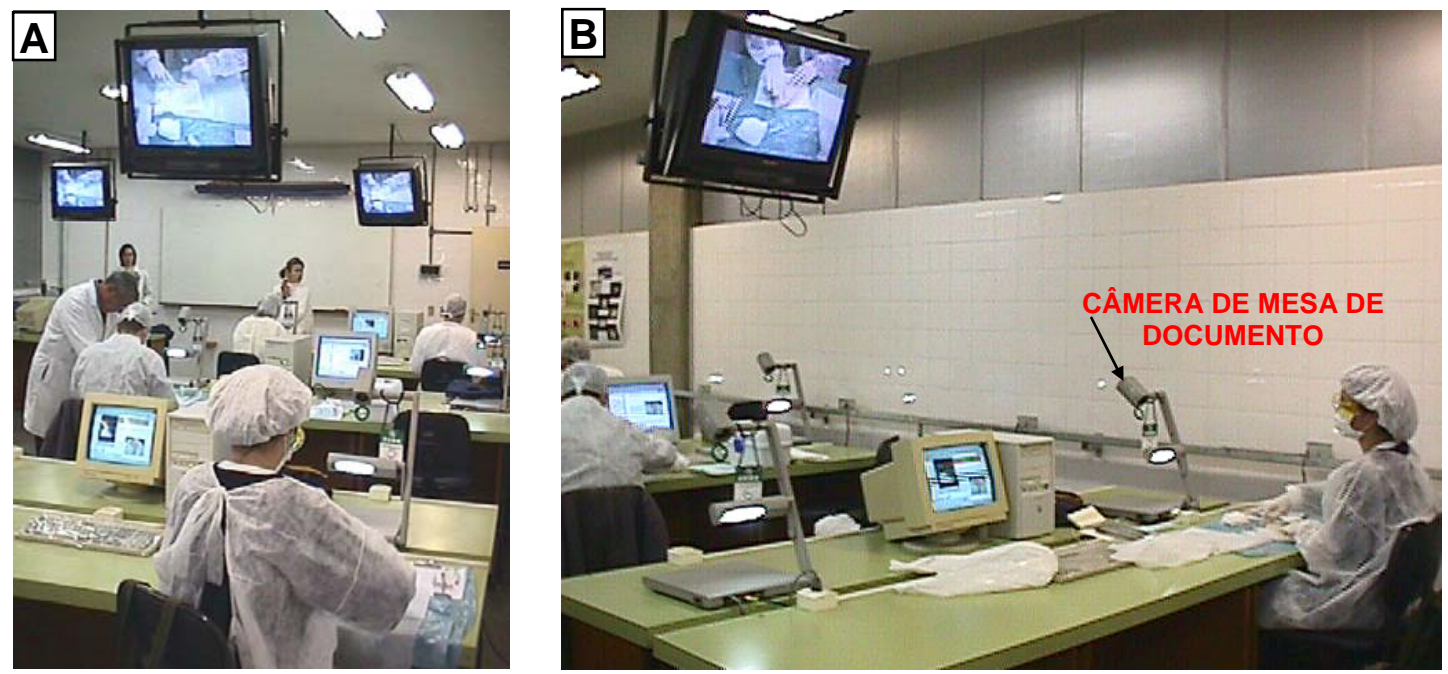

FIGURA 5.8 - Recursos tecnológicos disponiveis no dia do curso: circuito interno de televisão, o qual recebia imagens coletadas por microcâmeras de mesas de documento (B) focalizadas na área de trabalho do aluno, microcomputador contendo software de ensino a distância e centro controlador, à frente da sala, com ilha de edição, videocassete, microcomputador e microscópio, todos também conectados ao circuito interno de TV $(\boldsymbol{A})$
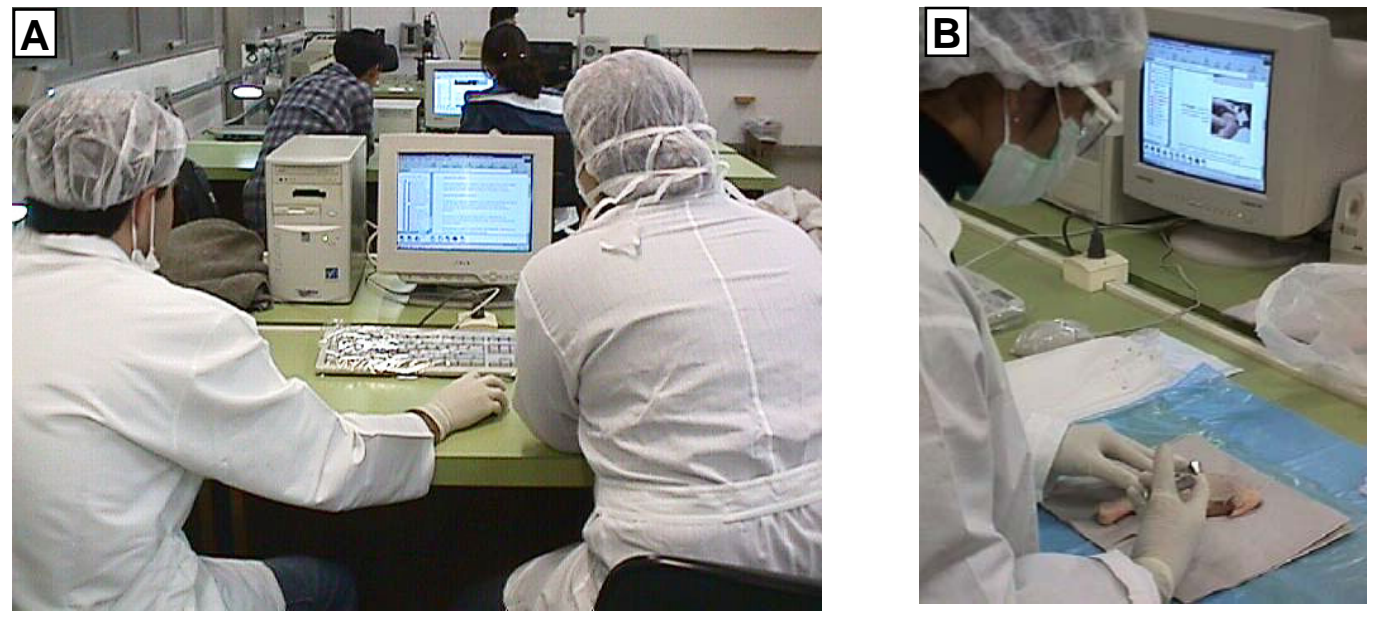

FIGURA 5.9 - A: Início do curso, em que os alunos se interam do "site" e consultam os fundamentos teóricos antes de iniciar os passos da técnica. A dupla em destaque encontra-se paramentada para dar início aos procedimentos cirúrgicos, diferentemente da dupla mais ao fundo. B: Aluna na segunda etapa do curso, aprendendo a dar anestesia. A página do "site" visualizada no monitor condiz, com sua ação, ou seja, a aluna segue o "site" passo-a-passo para executar a técnica cirúrgica 
Além das respostas do questionário, alguns momentos do curso que flagrassem comportamentos interessantes dos alunos foram também coletados. Esses momentos foram fotografados e ou filmados e gravados em fita, para posterior análise. Foram observados nessas fitas principalmente os tempos gastos pelos estudantes entre olhar a tela e executar o passo cirúrgico e a quantidade de retorno à tela para confirmação da posição da mão e do instrumental, do objetivo do passo, da região a ser explorada etc. Em geral, a seqüência do aluno era ler todo o capítulo referente à etapa da técnica, em seguida interpretar as imagens presentes, consultar sua área de trabalho (presença do instrumental e do material necessário para aquela etapa, posicionamento da perna de frango etc.) e iniciar o procedimento. Muitas vezes este era interrompido no meio para uma consulta na tela, ficando o instrumental solto sobre o campo para que a mão e o corpo pudessem ter acesso ao "mouse" e ao monitor do computador. Em outros momentos, viam-se posições totalmente anti-ergonômicas dos alunos, para ter acesso ao computador. Outras observações residiram principalmente no tempo individual em que cada aluno executou os passos da técnica, ou seja, cada dupla seguiu seu ritmo natural, estando cada uma das bancadas muitas vezes em etapas diferentes. A Figura 5.10 ilustra alguns desses momentos. 

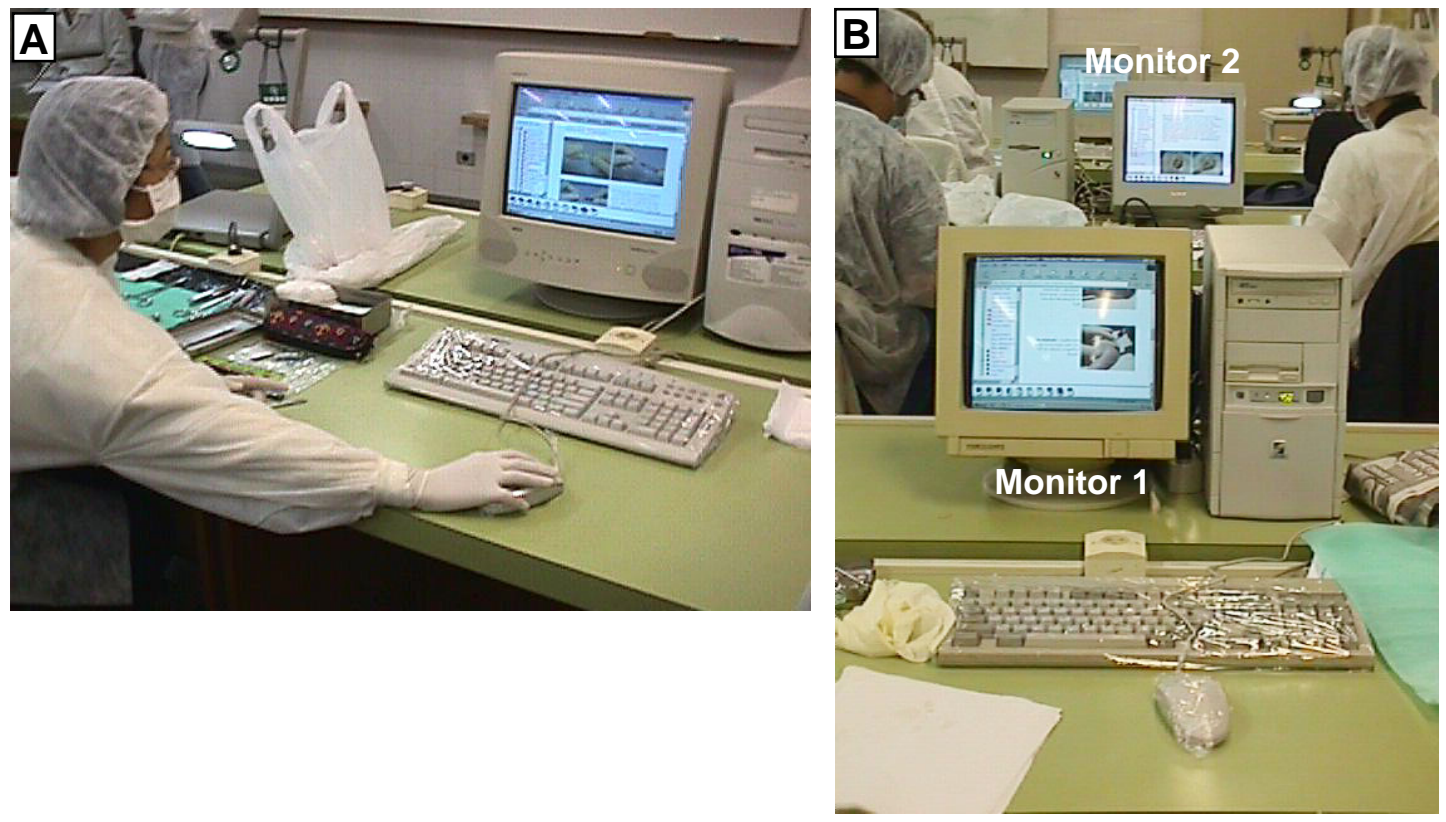

FIGURA 5.10 - A: Aluna acessando o "site" durante o curso. Observe como seu braço e seu corpo encontram-se esticados, em posição anti-ergonômica. B: Duas páginas distintas nos monitores 1 e 2 (com conteúdo referente à mesma etapa da técnica cirúrgica, porém com passos diferentes), demonstrando como cada dupla incutiu seu ritmo pessoal

\subsection{Protocolo preliminar de confecção de material didático "on line”} direcionado à área médico-odontológica

1. Delineamento de objetivos, temáticas e público-alvo: topicalizar, item a item, os objetivos a serem atingidos com o material, seu nível de abrangência (tomando como base, se necessário, aulas presenciais) e o público a que se destina, tal qual se faz ao confeccionar os materiais didáticos tradicionais.

2. Estruturação do banco de dados: estabelecer estratégias de formação do banco de dados, baseando-se em critérios relevantes de distribuição e 
classificação do material; deverá ser formado um banco para cada elemento de comunicação (texto, imagem, vídeo e som), cada qual com sua estrutura de palavras-chaves para recuperação da informação; essas palavras-chaves deverão traduzir pelo menos três características essenciais contidas no elemento armazenado; os bancos formados deverão ser passíveis de cruzamento entre si, utilizando-se, para isso, a rede de palavras-chaves gerada para cada um deles. As imagens deverão ser armazenadas em alta resolução (300 dpi).

3. Planejamento do conteúdo: estabelecer estratégias de divisão em tópicos do conteúdo e as conexões entre eles, com vistas a formar a rede de "links" inicial; estabelecer o "layout" básico do "site", considerando-se os princípios básicos de editoração de páginas para Internet e o público a que se destina.

4. Delimitação da equipe de produção: estabelecer a divisão de tarefas entre os participantes do projeto de confecção do material; a equipe deve ser formada por pelo menos um docente responsável pelo conteúdo, um técnico conhecedor da linguagem HTML e dois estagiários e ou monitores dedicados à manutenção da interatividade (respostas de "e-mails", participação em "chats", delineamento de estratégias de atualização do conteúdo).

5. Delimitação dos recursos tecnológicos a serem utilizados: deverão ser estabelecidas as estratégias de "hardware" e "software" a serem empregados no projeto, projetando o material para esse arsenal 
tecnológico. Recursos adicionais de interatividade (plug-ins, applets, JavaScript, ASP etc.) deverão ser considerados levando-se em conta a compatibilidade desses recursos com a forma de acesso pelo público. Se empregados gerenciadores de ensino a distância, prévia calibragem com a equipe técnica e os usuários deve ser realizada antes da confecção do material.

6. Confecção do material: iniciar a seleção e o processamento das imagens e do texto arquivados no banco de dados; o processamento de imagens e textos deve seguir os princípios básicos de veiculação de arquivos pela Internet (textos curtos e objetivos, imagens com no máximo 72 dpi e tamanho compatível com seu conteúdo, vídeos com sistemas de compressão e sob a forma de "clips" etc.); incluir a composição entre imagens (figuras, animações, vídeos) e o texto, a tradução dessa composição para a linguagem HTML e o incremento da rede de "links" (criação de conexões interpáginas, intrapáginas e “intersites”).

7. Estabelecimento da quantidade mínima de material: levar em conta o público a que se destina e o nível de abordagem do conteúdo (número de tópicos da matéria), para se produzir uma rede hipertextual mínima (a navegação deve visar a exploração, por parte do usuário, de pelo menos três páginas diferentes para cada tópico). Um nível de interação razoável deve visar a possibilidade de contato entre os usuários e os produtores (por "e-mail”") e a maior quantidade possível de ação do usuário sobre a página (por exemplo, inserção de exercícios a serem feitos diretamente no 
computador e "on line"). Avaliar a necessidade de disponibilizar o material para impressão, o qual, se feito, deve ser sob a forma de "download" do arquivo do conteúdo, este já diagramado para ser impresso.

8. Finalização do material: incluir o teste das páginas em diferentes navegadores e a checagem da fidelidade de todos os "links" e da eficiência dos recursos de interação.

9. Monitorização: deverão ser incluídos recursos que permitam o controle do número de acessos (inserção de contadores automáticos, de preferência em páginas estratégicas), com elaboração de relatórios semanais. É aconselhável a observação do público no início da aplicação do material, estabelecendo-se um prazo de calibragem entre a interface e o usuário, período em que serão feitos os ajustes necessários, principalmente de "layout". É aconselhável a inserção de sistemas de avaliação quanto à assimilação do conteúdo, bem como enquetes periódicas acerca do desempenho do material.

10. Peculiaridades pertinentes à conjugação entre uso do computador $\mathrm{e}$ atividades manuais: se o conteúdo incluir atividades manuais concomitantemente à consulta da página na Internet, os produtores devem conceber um "layout" em que o usuário utilize pouco o "mouse" e o teclado (página sem barras de rolagem, divisão do conteúdo em passos em que seja possível visualizá-lo integralmente e, ao mesmo tempo, trabalhar com as duas mãos na atividade proposta etc.). Instruções de 
proteção do equipamento (quanto a atividade manual envolver materiais que possam danificá-los) deverão estar claras e visíveis na primeira página.

11. Normativas mínimas: o conteúdo deve ser constantemente atualizado e o retorno de "e-mails" deve ser feito sistematicamente, sem falhas nos prazos estabelecidos para as respostas. Procurar não isolar o "site" da imensa rede hipertextual que é a Internet: estabelecer conexões com "sites" tematicamente mais próximos, ampliando as possibilidades de consulta. Atentar para os princípios éticos relacionados à veiculação da imagem dos pacientes. Atentar para os requisitos de autoria e permissão de cópia, os quais devem ser antecipadamente estabelecidos pela equipe em conformidade com a instituição-sede do material. 


\section{DISCUSSÃO}

Desenvolver este trabalho incitou o contato com duas experiências bastante distintas: a primeira diz respeito à técnica envolvida com a produção para a Internet, técnica essa que remete à ciência dos sistemas de rede e às linguagens de programação (HTML, Javascript); a segunda refere-se à sistemática pedagógica diretamente ligada ao desenvolvimento de materiais e cursos pela Internet, principalmente no tocante à aplicação de modelos de ensinoaprendizado, os quais diferem, em muito, do ensino dito tradicional. Portanto, nosso empenho em conceber esse trabalho concentrou-se nesses dois aspectos, fato que implicou o estudo de suas convergências e divergências.

Tanto em um como em outro campo do conhecimento, os dados da literatura são bastante escassos e pouco elucidativos. As principais experiências, as quais se concentram, como é possível notar pela revista da literatura, na Inglaterra e nos Estados Unidos, trazem resultados bastante particulares, uma vez que, ao se tratar de educação, as peculiaridades do público envolvido e da instituição participante são cruciais para a interpretação dos resultados. Em outras palavras, a carência de estudos sobre educação a distância utilizando a Internet em uma população brasileira dificultou o estabelecimento da metodologia. Essa dificuldade, ao mesmo tempo, animou-nos a empreender este 
trabalho, utilizando como tema uma das áreas da Odontologia — a Patologia — com grande potencial de interdisciplinaridade. Esse quesito interdisciplinaridade - foi o motivo do estabelecimento da estratégia metodológica deste trabalho, já que, para se empreender um projeto de produção de material didático, é necessário o estabelecimento de um objetivo geral bem definido (Antolí, 2000). Buscamos, pois, a interdisciplinaridade entre duas disciplinas, a saber, Patologia Geral e Patologia Bucal, valendo-nos do potencial que a estrutura hipertextual possui de promover intercâmbio entre as informações em níveis bastante complexos.

Como estratégia básica, estruturamos o material didático seguindo o modelo aplicado nas disciplinas para o ensino presencial. Assim, toda a estrutura dos "sites" foi desenhada com base nas atividades programáticas e curriculares estabelecidas por cada uma das disciplinas para o curso de graduação em Odontologia da USP. Esse aspecto é crucial para a discussão dos resultados obtidos, uma vez que, em nosso trabalho, não desenvolvemos cursos independentes e paralelos ao presencial, mas tão-somente um material didático complementar às aulas ministradas em sala de aula. Podemos dizer, portanto, que, nesta análise, as diretrizes pedagógicas até então estabelecidas para o ensino presencial aplicam-se de certa maneira à essa experiência com o não-presencial. Delimitar os limites dessa aplicação constitui um dos inúmeros pontos a serem discutidos neste trabalho.

Como primeiro passo, fizemos uma análise do público-alvo deste estudo. Na Faculdade de Odontologia da Universidade de São Paulo, até então nenhum 
trabalho havia sido feito com relação ao impacto dos computadores no dia-a-dia dos alunos. Não havia dados sobre a existência de computadores em suas casas, nem sobre o modo como utilizavam essas máquinas. Assim, achamos adequado entregar um breve questionário aos alunos do segundo diurno e do terceiro noturno (ano 2000), bem como aos participantes do curso de introdução à técnica cirúrgica, centrado no uso de computadores e da Internet. Vimos que os estudantes estavam tecnicamente preparados para o início do projeto: o Gráfico 5.4 (pág. 57) atesta que a maioria manipulava pelo menos dois "software", sabendo utilizar o Microsoft Word ${ }^{\circledR}$ e o Microsoft Power Point ${ }^{\circledR}$. O fato de saber manipular esses programas talvez não nos ajudasse a empreender a iniciativa, já que o grau de conhecimento de um aplicativo pode variar bastante. Todos os trabalhos que consultamos na literatura envolviam alunos de graduação que já tinham experimentado previamente cursos de informática, a maioria fazendo parte da estrutura curricular obrigatória do curso de Odontologia (Dowes, 1998; Scheleyer, 1998). Esse aspecto ajuda bastante os pesquisadores, pois implica o estabelecimento de uma população homogeneamente formada quanto a esse conhecimento específico. Como não temos em nossa estrutura curricular cursos de informática, o questionário constituiu somente um guia superficial no tocante à desenvoltura dos alunos perante os aplicativos. O mesmo se deu com a manipulação da Internet. Os Gráficos 5.6 e 5.7 (pág.59) mostram que pelo menos $70 \%$ do alunado acessa esse veículo pelo menos uma vez por semana. Não sabíamos ao certo como era esse acesso, mas nos baseamos no fato de a grande maioria já ter entrado em contato com a Internet. Na literatura, 
encontramos trabalhos que, previamente à instituição da Internet como ferramenta auxiliar no aprendizado, fora desenvolvido um programa disciplinar que visou o ensino de manipulação da WWW voltada para o aprendizado; os alunos aprendiam a acessar informações pela Internet com vistas à complementação de sua formação superior; só depois de terminado esse programa é que esses alunos tinham acesso aos materiais didáticos da instituição (Dowes, 1998; Scheleyer, 1998). Um dado interessante diretamente ligado a esse aspecto da necessidade de saber utilizar a Internet está contido no Gráfico 5.11 (pág.62), o qual demonstra que os acessos à Internet restringem-se a "sites" de entretenimento, seguidos por "sites" relacionados à Odontologia. O aluno, assim, parece estar mais envolvido com a Internet para o seu lazer do que propriamente como uma ferramenta de estudo. Porém, manifestaram o desejo de assim a utilizar, como atesta o Gráfico 5.12 (pág.63).

Além da ausência de um suporte curricular que suprisse a necessidade técnica de manipulação dos recursos computacionais, esbarramos também com a falta de um laboratório de informática apropriado para iniciativas de ensino nãopresencial, ou seja, com suporte físico e de equipamento computacional para pelo menos 80 alunos. Contamos com o dado obtido do questionário de que os alunos possuíam computador em casa (Gráfico 5.3, pág.56), fato que nos animou a continuar o trabalho, o qual foi estruturado baseado no fato de que os alunos fariam suas consultas predominantemente em casa e na sala pró-aluno da FOUSP. Isso gerou certos conflitos técnicos de compatibilidade entre o formato do conteúdo realizado, o tipo de navegador que o usuário dispunha e a configuração 
da máquina (velocidade de acesso, resolução do monitor etc.). Essas dificuldades foram sendo paulatinamente sanadas à medida que as reclamações dos usuários foram surgindo, até se chegar a um meio termo compatível com a maioria.

Esses obstáculos técnicos, manifestados no momento da implementação do material produzido, levaram-nos a considerar, como primeira normativa protocolar, o fato de que os projetos de ensino a distância devem visar, logo no início de sua formação, o tipo de público a que se destina e o arsenal tecnológico que este dispõe, tentando minimizar as diferenças de acessibilidade ao conteúdo. O ideal nas instituições de ensino é que o estudante possa optar pela infraestrutura do local de ensino e que o conteúdo esteja calibrado essencialmente para essa infra-estrutura, havendo homogeneidade de acesso à informação. Não se trata de descartar as atividades em casa; ao contrário, estas devem ser estimuladas e toda a linguagem adotada deve visar esse acesso individual pelo aluno. Mas, ao nosso ver, a instituição deve ainda conter a estrutura física e coletiva de acesso, estimulando o intercâmbio presencial, além do não-presencial. Fazem parte dessa estrutura laboratórios de informática bem equipados e adaptados a uma proposta de ensino. A respeito disso, Scheleyer, em 1996, observou que poucas escolas de odontologia norte-americanas estavam adequadamente equipadas para a aplicação dos recursos eletrônicos na educação. Tal qual esse autor, entendemos a presença da infra-estrutura física como um alicerce pedagógico, e não somente como um espaço tecnicamente bem equipado. Vale dizer que, durante todo este trabalho, em que participamos ativamente do contato do estudante com o computador, vimos que observar o aluno, as suas 
reações e atitudes perante a máquina, foi de crucial importância. Laboratórios de informática estruturados para serem alicerces pedagógicos seriam um bom local para a continuidade dessas observações.

Nosso público-alvo foi constituído predominantemente por mulheres em relação aos homens (Gráfico 5.1, pág.55) e por jovens entre 19 e 20 anos (Gráfico 5.2, pág.56). Vários autores têm relatado o excelente desempenho dos jovens diante dos computadores (Sandholtz et al., 1997; Horvath \& Teles, 2000), por vezes sendo bem mais favorável em relação ao dos professores (Sandholtz et al., 1997). Consideramos esse dado bastante satisfatório, uma vez que nosso projeto dependia de certa autonomia para o acesso às informações pela Internet: não havendo um curso prévio de Informática e considerando que toda consulta seria feita em casa, o fato de termos jovens como co-partícipes do projeto supriria as ausências de um “contexto informático” mais bem estruturado, tendo como base o princípio de que os jovens manipulam com mais facilidade as linguagens das interfaces computacionais (Lévy, 1996; Sandholtz et al., 1997; Cooper, 2000). Sob certo aspecto, nosso trabalho envolvendo esse tipo de público é inovador, uma vez que a grande maioria das iniciativas com ensino a distância na área médico-odontológica está ligada a estudantes de pós-graduação e a profissionais da área (Holborow \& Kean, 1991; Radford, 1994; Smith et al., 1995; Heestand et al., 1996; Smith et al., 1998; Simpson et al., 1999; Gjerde \& Shapleigh., 1999).

Além de questões curriculares, de infra-estrutura e de tipo de público, esbarramos também com obstáculos pertinentes à linguagem hipertextual e aos 
temas "Patologia" e "Cirurgia" selecionados. Ao elaborarmos a estratégia de abordagem desses temas considerando-os como hipertextos, notamos certas diferenças de concepção entre materiais da área médico-odontológica, da área de exatas e da área de humanas. A revisão de alguns trabalhos utilizando a Internet, produzidos na Universidade de São Paulo (Novelli et al., 2001), confirmou a existência dessas diferenças: vimos que a área de biológicas aborda conteúdos com várias imagens mesclando textos; já a área de exatas possui trabalhos com textos mais curtos, concisos, e imagens mais escassas; por fim, a de humanas reúne produtos contendo textos longos e praticamente sem a presença de imagens. A partir dessas tendências, consideramos que um material para Internet pertencente à área de biológicas, ao possuir maior quantidade de imagens, é mais complexo de ser produzido. Baseamos essa consideração no fato de que, em termos técnicos, é mais trabalhoso estruturar um bom hipertexto com imagens, principalmente se essa imagem for também um nó da grande matriz de significação (ela tendo um significado que se articula no plano das imagens e no plano do texto concomitantemente) (Duchier, 2000; Leão, 1999). Essa complexidade se dá pelo fato de fazer parte de toda a rede de significação um elemento de natureza diversa do texto escrito, que contém seu campo semântico próprio. Ademais, as imagens, assim como o texto, podem ser lidas de diferentes maneiras (mesmo as técnicas, como é o nosso caso); essas diferentes leituras devem ser orientadas para comporem coesamente com o texto (por exemplo, por intermédio de legendas, setas e letras dentro das imagens etc.), delimitando-se os diferentes sentidos que ela possui (Santaella \& Nöth, 1999). Além dessa 
delimitação de sentidos, estes devem estar articulados entre si e com outras imagens por intermédio de "links". Ou seja, é necessário, teoricamente, para se produzir um recurso hipermídia, fazer um hipertexto somente com imagens, um hipertexto somente com textos e um hipertexto com textos e imagens. O mesmo raciocínio pode ser aplicado para outros elementos de comunicação (som, vídeo e animações, por exemplo), o que aumenta sobremaneira a complexidade de produção (Leão, 1999).

Um outro ponto envolvido com o uso de imagens em hipertextos para Internet são as limitações de acessibilidade (arquivos "pesados") e os compromissos com legibilidade e qualidade (necessidade de boa resolução). Os formatos de arquivos de imagem atualmente são dotados de filtros de compressão (por exemplo, os formatos JPEG e GIF), o que diminui o seu tamanho em termos de bytes, contornando o problema da acessibilidade (o arquivo não demora tanto para ser carregado no "site"). Contudo, ao mesmo tempo, há perda da qualidade da imagem, a qual deve ser sanada por intermédio de um bom tratamento da imagem. Isso quer dizer que deve necessariamente ser incluído no protocolo de produção de hipertextos para a área médicoodontológica um gasto substancial de tempo no tratamento das imagens, a fim de se manter sua legibilidade e qualidade sem alterar a acessibilidade.

O tema "patologia" ainda envolve imagens de diversas naturezas (macroscópicas, microscópicas, radiográficas etc.), cujos originais possuem diferentes tamanhos e materiais e, portanto, exigem equipamentos diversos de digitalização. Isso implica o estabelecimento de estratégias de tratamento 
diferenciadas segundo a forma de digitalização e o tipo de conteúdo que essas imagens abarcam. Por exemplo, para se ilustrar uma lâmina — pelos resultados, vemos que a maioria das imagens dos "sites" foram de histológicos (Tabelas 5.3 e 5.5, pág.66 e 68) —, são necessários pelos menos dois aumentos ou dois campos distintos (ou até mesmo ambos), os quais devem estar com brilho, cor e contraste semelhantes. Isso nem sempre é possível de ser obtido diretamente pelo equipamento de digitalização sem calibragens prévias. Ou seja, para cada caso e tipo de material, são necessárias configurações diferenciadas do "scanner", as quais devem estar devidamente protocoladas.

Considerando-se previamente esses particulares técnicos, os bancos de dados para esta pesquisa foram estruturados tendo-se em mente uma ampla abordagem das disciplinas envolvidas. Foram digitalizados textos e imagens com o intuito de se criar um acervo digital amplo. No caso da Patologia Geral, 90\% do acervo de peças macroscópicas e de lâminas foi digitalizado, gerando uma facilidade de consulta e manipulação desses elementos. O mesmo se deu para a Patologia Bucal. Assim, o conteúdo produzido, além de ter um potencial didático, constitui também uma fonte de informações sobre o acervo de trabalho dos docentes. No total, foram armazenadas neste trabalho 1226 imagens, somando-se o total dos três bancos (Patologia Bucal - Tabela 5.3 (pág.66); Patologia Geral Tabela 5.5 (pág.68); curso de introdução à técnica cirúrgica - pág.69), quantidade significativa que ilustra as informações de patologia transmitidas no curso de Odontologia da USP. Temos, portanto, um retrato digital preliminar dessas 
disciplinas na FOUSP. Esse acervo estruturado permite, entre outras funções, maior veiculação nas mídias atuais e facilidade de recuperação da informação.

O banco de textos foi concebido tendo-se também em mente uma abordagem ampla das disciplinas (Tabelas B.2 e B.4, págs. 164 e 165), tal qual o das imagens. Procurou-se preservar as características do conteúdo transmitido nas salas de aula, ou seja, foi mantida a organização programática adotada pela disciplina. Os tópicos abordados foram os mesmos do curso presencial, havendo certas adaptações em função da estrutura hipertextual (Monteith, 1998). Para a Patologia Bucal, além da matéria prevista curricularmente, foram incluídos textos descritivos dos casos clínicos (70 textos), com suas características de organização e de terminologia, o que fez com que os alunos entrassem em contato com essa forma textual de comunicação, nem sempre bem explorada no curso presencial devido a limitações de carga horária. Para a Patologia Geral, os acréscimos concentraram-se nos textos complementares (37 textos), em que o aluno era remetido para as disciplinas anteriormente cursadas, entrando em contato novamente com seus jargões específicos. A consulta a cadernos de anotações feitas para essas disciplinas já cursadas e aos livros adotados por cada uma delas possibilitou a manutenção do seu estilo e vocabulário, constituindo fontes de recordação e de complemento informacional. Assim, os bancos de textos formados caracterizam-se por armazenarem conteúdos com diferentes estilos e terminologias.

O banco de textos, como já dissemos, deve estar diretamente articulado ao banco das imagens (figuras estáticas, animações, vídeos). O ideal é que sejam 
formados paralelamente, ou seja, que haja complementaridade entre ambos em um primeiro nível da informação. Isso quer dizer que, à medida que um texto é gerado, deve ser armazenada pelo menos uma imagem que faça referência direta ao conteúdo textual. Essa conduta facilita, no futuro, a criação do hipertexto contendo imagem e texto, uma vez que um pólo de significação está potencialmente formado já na fase de banco de dados. Ou seja, são armazenados, na verdade, blocos compostos por imagem e texto. Ao mesmo tempo, a criação de palavras-chaves (no mínimo três) de cada elemento do banco (seja ele texto ou imagem) também é essencial para a formação do hipertexto no futuro. $O$ cruzamento dessas palavras-chaves nos dois bancos possibilita uma visualização do que pode ser o hipertexto, uma vez que as conexões mínimas já estão estabelecidas. Obviamente essa conduta nem sempre é passível de realização, como descrevemos nos resultados. Por exemplo, nem sempre foi possível digitar o texto e escanear as imagens dos casos clínicos concomitantemente. Contudo, a conexão entre os dois bancos deve sempre estar na mente do produtor.

Após a estruturação dos bancos de dados, os "sites" foram confeccionados de acordo com a proposta de comunicação a que se destinariam. O "site" da Patologia Bucal foi composto para transmitir informações de um banco de situações clínicas em Odontologia, adquirindo uma seção especial para a graduação — a dos exercícios —, que visa facilitar o entendimento dos casos clínicos, já que estes são de lesões raras e ou de tratamentos específicos e inéditos, envolvendo outras áreas afins e sendo de difícil compreensão por parte de um aluno de graduação. Seu "layout", como foi comentado nos resultados, permite o 
constante acesso à base de dados. Vemos, por intermédio da Tabela 5.6 (pág.71), que se trata de um "site" grande (com 940 arquivos no total) e com uma rede de hiperlinks complexa (2309 nós), a qual remete a informações internas e externas ao "site".

Já o "site" da Patologia Geral foi concebido para ser um livro eletrônico que contém um banco de imagens. Ele também é composto por uma seção de exercícios que visam, sobretudo, fazer com que o aluno acesse o conteúdo do "site" de uma forma direcionada; ou seja, os exercícios orientam os alunos a clicar em determinados "links" que promovem um conhecimento diferente daquele obtido a partir de uma navegação mais linear. Vale dizer que esse tipo de navegação não está descartado; ao contrário, está previsto no "site" por intermédio de botões auto-explicativos que levam a páginas anteriores e posteriores. Também é um "site" bastante "volumoso", com 890 arquivos e 4034 hiperlinks (Tabela 5.7, pág.71).

Vemos que, em relação ao "site" de Patologia Bucal, o da Geral possui uma árvore de "links" mais complexa (Tabelas 5.6 e 5.7, pág.71). Isso é devido principalmente à organização da informação que existe em um "site" e em outro. $\mathrm{Na}$ Patologia Geral, para um melhor entendimento dos tópicos abordados, é necessário que estes estejam conectados entre si. Por exemplo, para entender o que é "esteatose", ligado a esse termo deverão vir necessariamente outros, como “degeneração gordurosa", "lesões reversíveis” etc., pois cada um desses conceitos contextualiza o processo geral citado. O “site", assim, está configurado a atender essa necessidade didática inerente ao estudo dos processos gerais. Por outro lado, 
o "site" da Patologia Bucal é baseado em pequenas histórias de pacientes, as quais se encerram em si mesmas, salvo na informação do diagnóstico, o qual é potencialmente conectável a outros diagnósticos semelhantes ou mais gerais.

Além dessa questão da organização da informação em função do tema, a diferença na rede de "links" deve-se também à configuração do "layout": na Patologia Bucal, todos os "hiperlinks" necessários a uma boa navegação estavam constantemente disponíveis ao usuário por intermédio de uma composição por dois quadros, não sendo necessária a repetição deles em cada uma das páginas do “site". Essa repetição foi realizada no "site" da Patologia Geral, já que este foi composto por somente um quadro, sendo necessária, em cada página, a inserção dos "hiperlinks" de navegação, o que incrementou quantitativamente sua rede de conexões e nós.

O "site" do curso de introdução à técnica cirúrgica foi desenhado de forma que o usuário pudesse acessar, a todo momento, qualquer módulo do curso, enviar "e-mails" ou entrar em contato com o "site" do Laboratório de Informática Dedicado à Odontologia e a Disciplina de Cirurgia. Em comparação aos "sites" da Disciplina de Patologia Bucal e Geral, o do curso é bem menor (271 arquivos no total - Tabela 5.8, pág.71), pois contém informações bastante específicas a um dos tópicos de cirurgia. Além disso, essas informações estão organizadas sob a forma de curso, com aulas a serem cumpridas segundo uma ordem predeterminada pela estratégia pedagógica adotada, o que implica restringir, sob certo aspecto, a navegação e, por conseguinte, a rede de hiperlinks, tornando-a não tão livre como nos demais "sites" analisados. 
Essa breve descrição da estrutura dos “sites" traduz a intenção incluída neste trabalho em se estudar o impacto da Internet no ensino de graduação, valendo-se para isso de três configurações bastante diferentes. O "site" da Patologia Geral representa a contrapartida das ciências básicas na formação do odontológo. O "site” da Patologia Bucal, por outro lado, contém as informações básicas aplicadas ao cotidiano da atividade odontológica. Por fim, o "site" do curso de introdução à técnica cirúrgica representa o plano curricular responsável pela formação prática do odontológo, o lado técnico da profissão. Assim, buscou-se, por intermédio dessa tríade hipertextual, abarcar uma boa parte do contexto de ensino-aprendizado envolvido com a Odontologia, transpondo esse contexto para a Internet. A intenção, assim, foi de avaliar o impacto dessa tecnologia nos diferentes ambientes de aprendizado ao qual está submetido o futuro odontólogo.

$\mathrm{Na}$ literatura não encontramos nenhum trabalho que fizesse uma análise semelhante a essa, ou seja, que avaliasse, de uma forma global e conjunta, o impacto das novas tecnologias de informação em momentos diferentes de aprendizado. Os trabalhos na área médico-odontológica restringem-se a descrever a estrutura do curso a distância ou do material vinculado na Internet, fornecendo pouco ou nenhum dado oriundo da aplicação desses materiais a públicos específicos.

Vimos também que, nos "sites" analisados na revista da literatura, o material didático disponível restringia-se a uma disciplina da faculdade de odontologia da instituição ou, até mesmo, limitava-se a um tópico de todo o 
conteúdo programático. Nesses "sites”, ainda, vimos que inúmeros programas ou consórcios entre instituições estão sendo estruturados nas universidades para promover o ensino a distância, bem como os chamados "centros de educação continuada" baseados no ensino não-presencial. Em nenhum desses "sites" encontramos informações que esclarecessem o impacto dessas iniciativas na instituição e no corpo discente e docente, nem tampouco indicadores de aprendizado e de custo-benefício.

Acreditamos que a escassez de dados seja oriunda de dois motivos principais. Primeiro, a Internet é um recurso extremamente novo (por volta de 1993 é que começou sua difusão para a população acadêmica e geral como um todo (Cooper, 2000); no Brasil, essa data fica por volta de 1996 (Niskier, 1999)), cujas potencialidades ainda estão por vir a ser delineadas. Lévy (1996) analisa essas potencialidades tomando como ponto central o conhecimento, ou seja, a forma como as inteligências individuais se articulam para formar o coletivo pensante. Nessa análise, a qual é totalmente social, entram em questão noções de democracia e liberdade de ação, partes fundamentais para o estabelecimento de novas pedagogias. Já Negroponte (2000) direciona suas análises para a forma como o desenvolvimento tecnológico caminhará daqui para frente, encarando com otimismo as transformações ao projetá-las no mundo capitalista. Esses dois filósofos, atualmente bastante discutidos na mídia, estão ainda criando modelos lógicos que expliquem esse novo fenômeno da Internet, o qual influencia praticamente todas as áreas de ação humanas (políticas, econômicas, artísticas, comportamentais, sociais etc.) e não só educacionais. Não existem, portanto, 
modelos e previsões já consolidados. Um segundo motivo da escassez de dados seria devido ao fato de que os programas de cursos a distância estão tendo o seu "boom" agora, no fim do século (entre 1998 e 2000), estando os protocolos ainda em desenvolvimento (Niskier, 1999).

Apesar de não haver ainda indicadores sólidos de aprendizado a distância, os autores citados na literatura (Sandholtz et al., 1997; Registro et al., 2001; Azevedo, 2000; Gomez, 2000) são unânimes em afirmar que os alunos tornam-se mais ativos no processo de ensino-aprendizado quando este é mediatizado pelo computador. As decisões tomadas, a seleção da informação, a produção do conhecimento é totalmente centrada no aluno. Alguns pesquisadores (Sandholtz et al., 1997; Gomez, 2000; Vieira, 2000) orientam seus estudos com enfoque sobre as premissas do construtivismo — linha pedagógica estabelecida por Piaget que focaliza a criatividade do aluno e a produção do conhecimento por intermédio de ações ativas do corpo discente — , ou sobre as premissas do construcionismo defendido por Papert, que afirma ser o computador um forte contribuinte para o aprendizado (Vieira, 2000). Não foi enfoque deste trabalho analisar a eficácia de determinada estratégia pedagógica, mas somente interpretar as atitudes dos alunos de graduação em Odontologia diante de uma nova ferramenta de aprendizado via computador. Contudo, consideramos as fundamentações teóricas pedagógicas e as aplicamos, quando pertinente, nas interpretações dos resultados obtidos a partir dos testes dos "sites.

Para nós, o material didático criado reflete os objetivos a serem atingidos por uma estratégia pedagógica. Um dado interessante que tem se revelado nas 
produções para Internet atualmente é o fato de que os materiais disponibilizados na rede quase não diferem do apresentado em sala de aula. Detectamos isso no levantamento tanto dos "sites" da USP (Novelli et al., 2001) quanto dos "sites" das faculdades de odontologia nacionais e internacionais realizado neste trabalho. O professor produz um texto em Microsoft Word ${ }^{\circledR}$ ou uma apresentação em Microsoft Power Point ${ }^{\circledR}$ para utilizar nas aulas e imediatamente os disponibiliza na rede, sem uma adequação dessa linguagem à do hipertexto. As conversões para HTML são feitas automaticamente, sem a preocupação de se gerar uma árvore de "links" mínima. Assim, detectamos não haver uma estratégia pedagógica específica para o ensino via Internet, e sim somente uma transposição do ensino presencial para o não-presencial.

Tentamos, com o material produzido, não seguir essa linha. Os três "sites" foram concebidos a partir de um planejamento direcionado à produção de hipertextos, o que implica atender a quesitos mínimos, como navegabilidade e interatividade, fatores indiscutivelmente decisivos para o delineamento de posturas pedagógicas diferenciadas das assumidas em sala de aula (Lévy, 1996). A criação de uma rede complexa de "links" e a inserção de GIFs animados (imagens em movimento) e exercícios a serem respondidos e enviados diretamente pelo computador (e não por intermédio da impressão dos mesmos) constituem indicadores técnicos dessa intenção.

Além da interatividade e da navegabilidade, tentamos seguir os princípios delineados por Lynch \& Norton (2000); O’Dowd (2000); Nielsen (2000) e, principalmente, por Schultz et al. (2000). Assim, os textos presentes nos "sites" 
não são longos (sendo invariavelmente seguida a regra "um tópico, uma janela", apontada por Schultz et al. (2000)) e, na medida do possível, bem ilustrados por imagens (na média, pelo menos uma imagem para cada dois parágrafos). Invocamos, sobretudo, uma aspecto de ludicidade no material, recurso que auxilia bastante na comunicação via Internet. No "site" de Patologia Geral, por exemplo, criamos um personagem, caricatura de um dos professores da disciplina, que se relaciona com um cientista, também caricaturesco. O professor está mais envolvido com questões de patologia direcionadas ao cotidiano da clínica, enquanto o cientista dedica-se a estudar a patologia pela morfologia (peças macroscópicas e microscópicas). Foram criadas polêmicas entre os dois personagens, cuja resolução era solicitada aos alunos nos exercícios. Esses personagens serviram também de guia para a navegação nas páginas e para dicas de estudo. Gomez (2000) ressalta a necessidade de recursos lúdicos nos materiais eletrônicos, os quais constituem excelentes veículos de avaliação quanto à atividade colaborativa do aluno em criar e fornecer informações para toda a rede.

A aplicação desse material nos alunos de graduação foi realizada em uma época que, sob certo aspecto, favoreceu nosso trabalho. Os alunos acessaram os "sites" no primeiro semestre de 2000, época na Universidade de São Paulo em que ocorreram greves, paralisações e movimentos estudantis, o que acarretou a ausência de aulas e a alteração, conseqüentemente, do programa das disciplinas. Além disso, as bibliotecas e os locais para "xerox" estavam fechados, o que dificultou o acesso dos alunos a livros e outras fontes de consulta indicadas pelas disciplinas. Nesse contexto, os "sites" representaram uma excelente ferramenta 
para atenuar essas carências, sendo passível a consulta às informações dos cursos em casa, o que favoreceu o maior envolvimento do corpo discente neste projeto.

Já por esses acontecimentos, notamos que a produção de materiais “on line", até certo ponto, substitui alguns setores fornecidos pela instituição, a saber, a consulta a docentes sobre informações secundárias (informações essas sem ser de caráter complementar nem tampouco elucidativo de matérias já dadas em aula, atividade que julgamos ainda ser vital a presença do docente) e os sistemas de bibliotecas e "xerox" (cada aluno tem disponível em casa todo o material, podendo consultá-lo e imprimi-lo como desejar). Além disso, o fato de poder acessar de casa o conteúdo pode minimizar a permanência ociosa dos alunos na instituição (por exemplo, eliminando "janelas" da grade curricular), diminuindo o gasto em termos de infra-estrutura. Assim, a produção de conteúdos para Internet, por si só, assume um papel importante no processo de ensinoaprendizado, na medida em que se transporta parte do sistema institucional para a casa do aluno.

Esse aspecto torna-se bastante interessante quando se produzem cursos visando públicos distantes do local de origem. Em alguns relatos da literatura, os cursos a distância estão direcionados para atingir alunos localizados em áreas de difícil acesso (áreas rurais, territórios isolados por cordilheiras, ilhas etc.) e distantes dos grandes centros educacionais, os quais ficam invariavelmente nos centros urbanos (Stanton \& Grant, 1995; Simpson et al., 1999; Heald; Kelly, 2000). Por esses programas, regiões distantes se conectam e se atualizam, entrando em contato com instituições virtuais. Levando-se em conta essa 
característica dos cursos "on line", as iniciativas de cursos a distância no Brasil seriam bastante promissoras para o País se direcionadas a transmitir informações de centros educacionais emergentes para as regiões ainda carentes de recursos.

Pensar acerca de políticas educacionais sobre ensino a distância pode facilmente suscitar discussões envolvendo o papel das universidades brasileiras públicas em relação às novas tecnologias educacionais. Contudo, esse tema não é enfoque deste estudo. Citamos esse aspecto difusor dos cursos a distância porque ele se desenvolveu naturalmente em nosso trabalho. Recebemos, durante todo o ano de 2000, "e-mails" de alunos e docentes de outras universidades brasileiras, latino-americanas e norte-americanas (de odontologia ou da área de saúde em geral) parabenizando-nos pelos "sites" e solicitando a utilização destes. Nenhuma iniciativa foi realizada por nós para que isso fosse desenvolvido. A própria Internet promove esse tipo de intercâmbio (Putten Jr., 1996), e negá-lo é limitar suas possibilidades de comunicação e difusão. Não nos preocupamos com questões de autoria que essas ações pudessem acarretar nessa fase do projeto; dessa forma, estimulamos esse contato e a utilização do material por outras unidades e instituições, com o objetivo de avaliar, no futuro, suas conseqüências.

Vale lembrar que todas as medidas de garantia quanto aos direitos de cópia do material e de preservação da imagem dos pacientes foram tomadas, inclusive os "sites" não foram submetidos aos sistemas de busca da Internet, com o intuito de manter restrito o público usuário. Obviamente que o conteúdo desenvolvido não está isento de ser submetido à cópia ilegal, pois a própria tecnologia de base (o sistema de redes, a linguagem HTML etc.) ainda não 
possibilita esse nível de segurança e garantia. Mas julgamos que esse aspecto não deve assumir dimensões tais a ponto de frear iniciativas de pesquisa com esses meios. Acreditamos que ações de controle de autoria devam ser assumidas só depois de testados esses veículos de comunicação para finalidade educacional e levantada grande parte de suas características e impactos. Lembramos que isso já vem sendo feito para os recursos da Internet direcionados ao comércio e ao lazer (Nielsen, 2000); para o ensino a distância, as normativas ainda estão se consolidando, tanto no exterior quanto no Brasil (Niskier, 1999).

De qualquer maneira, o desenvolvimento de material didático para Internet está diretamente atrelado a uma certa "responsabilidade educacional generalizada", isto é, o produtor, ao fazer o material, deve estar ciente do grande potencial difusor das informações ali contidas e, na medida do possível, deve manter sob controle essa difusão por intermédio do constante intercâmbio com os usuários. Esse controle deve visar, sobretudo, o impacto que a forma pessoal do produtor de organização do material acarretou sobre o usuário distante.

Essa "responsabilidade educacional generalizada" individual do produtor poderia estar atrelada a centros dedicados ao controle e organização do material "on line" produzidos pela instituição. A necessidade da presença desses centros ficou patente no relatório em que foi realizado o levantamento dos "sites" da USP (Novelli et al., 2001). Por esse levantamento, notamos que poucas unidades pertencentes à área de Humanas possuíam "sites" contendo material didático disponível; o mesmo não pôde ser dito das instituições na área de Exatas, principalmente a Escola Politécnica, em que praticamente todos os 
departamentos e disciplinas estão quase ou inteiramente com seus conteúdos disponibilizados na rede (tanto para graduação quanto para pós-graduação). $\mathrm{Na}$ área de Biológicas, destacam-se o Instituto de Biociências, com várias disciplinas contendo material didático no "site", e a Faculdade de Medicina, com produção significativa; o restante das unidades praticamente não tinha material ou exibia uma ou duas disciplinas com tal. Uma das conclusões desse relatório é que provavelmente existam mais conteúdos do que os apontados pelos observadores da pesquisa, contudo estes não estão acessíveis por intermédio de "links" diretos no "site" da faculdade ou escola (Preston (1997) também concluiu isso ao analisar cerca de 86 faculdades de odontologia, cujos conteúdos encontravam-se em ambiente Intranet). Assim, uma sugestão de política institucional a ser adotada pela Universidade seria de que todo conteúdo produzido pelo docente ou aluno (previamente orientado pelo professor) deveria necessariamente estar acessível para toda a comunidade uspiana (e exterior, dependendo das políticas de divulgação adotadas). Essa tarefa "unificadora" em prol da divulgação da diversidade acadêmica poderia ser realizada por centros especializados em ensino a distância, diretamente ligados a órgãos centrais da instituição. A tarefa desses centros seria, a nosso ver, produzir uma "universidade paralela" à tradicional, com um corpo dirigente próprio e com controle da difusão das informações.

As instituições educacionais deverão se posicionar quanto ao ensino a distância, já que essa área tem sido, nos dois últimos anos, alvo das empresas comerciais, as quais têm ditado as normas de condução desse processo (Peterson, 
1999). A parceria entre a instituição e a empresa talvez seja um caminho promissor, que merece reflexões imediatas.

Do teste monitorado com os alunos, realizado no Laboratório de Informática Dedicado à Odontologia, chegamos a duas conclusões principais. A primeira diz respeito ao conhecimento prévio do aluno quanto ao manejo do computador e da linguagem estruturada em hipertexto. Notamos que boa parte dos estudantes observados não revelou qualquer problema quanto a isso, mesmo aqueles que utilizaram a plataforma Silicon Graphics ${ }^{\circledR}$, cuja interface gráfica é um pouco diferente da dos PCs com Windows $98 \AA$. Esses alunos que estavam manipulando a Silicon - e que nunca o tinham feito antes — imediatamente gravaram os mecanismos básicos de cliques, não sendo um problema a mudança de plataforma. Além disso, não revelaram impaciência ou dificuldade na digitação, a qual não constituiu um empecilho para a performance na execução dos exercícios. Concluímos, assim, que o aluno de graduação em Odontologia já chega tecnicamente apto na faculdade a ter contato com iniciativas de ensino pela Internet, o que confirmou nossas hipóteses levantadas pelo primeiro questionário A1 (Anexo A), já comentadas nos resultados e nesta discussão.

Uma segunda conclusão diz respeito à participação do setor de informática da instituição e da necessidade de infra-estrutura dedicada ao ensino a distância. Um dos pontos mais críticos desse teste foi o fato de alguns alunos perderem seus exercícios devido à ineficiência da interface e da estrutura de 
recepção dos dados ${ }^{1}$. Por não termos um servidor local (utilizamos um sediado no Centro de Computação Eletrônica da USP, cujo acesso é mais restrito), não foi possível o desenvolvimento de programas computacionais (tipo CGI, por exemplo) que possibilitassem o controle do envio de mensagens. Esses programas, dentre outras ações, confirmam o recebimento dos dados enviados pelo usuário por intermédio de mensagens e fazem um "backup" dessas informações. Além disso, o sistema de abertura de janelas em cada questão dos exercícios e a necessidade de navegação para respondê-los constituíram ações que colocaram em risco as respostas inseridas nos campos dos exercícios. Conseguimos sanar em parte esses problemas, adotando-se estratégias que não demandaram tanta navegação e consulta, nem abertura em demasiado de janelas. Vimos, contudo, que a adoção de modelos de exercícios a serem feitos "on line" deve estar conjugada a programas computacionais que garantam sua gravação concomitantemente às respostas (por exemplo, à medida que o aluno clica em um "link" de consulta, as informações dos campos já digitadas por ele são enviadas automaticamente para o servidor como uma forma de "backup" parcial, sendo passível ao aluno a recuperação dos dados a qualquer momento).

A perda das informações digitadas em campos de formulários pode, em parte, ser solucionada utilizando-se "software" de ensino a distância. Contudo, nossa experiência com um deles, o TopClass ${ }^{\circledR}$, utilizado no curso de introdução à técnica cirúrgica, revelou que esses programas estão direcionados à aplicação de

\footnotetext{
${ }^{1}$ Queríamos manter uma certa interatividade nos "sites", como comentamos anteriormente, e para isso utilizamos formulários contendo campos de preenchimento com ação programada para enviar os dados por "e-mail". Essa ação independe da configuração de programas específicos nos servidores.
} 
exercícios como uma forma de avaliação dos conhecimentos adquiridos pelo aluno durante os módulos do curso, sendo mais condutistas (Gomez, 2000) e não tanto voltados ao estímulo à busca de novos conhecimentos e à articulação de informações. A idéia é que o aluno não consulte as páginas do curso, sendo avaliado pelo grau de assimilação e memorização do conteúdo. Os gerenciadores de ensino a distância garantem certos aspectos técnicos envolvidos com a interatividade, mas sua adoção deve ser bem pensada, uma vez que a estrutura de curso gerada por eles pode não condizer com a estratégia pedagógica adotada.

Os limites do ambiente tecnológico descritos neste trabalho remetem a uma questão essencial: a necessidade da técnica. A educação a distância atualmente está baseada em uma tecnologia que ainda é bastante específica e dependente de profissionais que a dominam. Como dissemos no início desta discussão, o projeto de ensino não-presencial possui uma boa parte direcionada à pedagogia e outra significativa direcionada à tecnologia. Optamos, primeiramente, em desenvolver nossas habilidades técnicas por intermédio do aprendizado das linguagens HTML e JavaScript, bem como pela interação do funcionamento dos sistemas de redes e de servidores. Só depois de dominada a tecnologia é que iniciamos o desenvolvimento do conteúdo, o qual, como já dissemos, em termos pedagógicos, em muito é semelhante ao transmitido em presença. Podemos dizer, assim, que este trabalho foi dedicado à técnica do ensino a distância, e não tanto às suas fundamentações filosóficas e pedagógicas.

Não resistimos, porém, em citar um filósofo que virou técnico por alguns momentos. Lévy (1996) comenta que, só depois de participar da confecção de 
sistemas computacionais especialistas, tornou-se um "ator da evolução técnica"; em outras palavras, enquanto filósofo, Lévy fazia suas análises do exterior de todo processo; depois de dominar o ambiente da técnica, passou a entender melhor as dimensões que as novas tecnologias assumem e as suas reais características. Citamos essa passagem por acreditarmos que adentrar a esse novo paradigma da educação implica conhecer suas linguagens e seus mecanismos como um técnico e executor, e não só como um expectador. Tal qual Lévy, o docente deve se interar das possibilidades que as interfaces e a linguagem estruturada em hipertexto geram para produzir seu material. Para isso, o básico da técnica deve ser dominado. Executar essa ação praticamente não difere daquela desenvolvida pelo corpo docente quando em contato com a tecnologia do "slide": o professor aprendeu a fotografar seu próprio material, mas não necessariamente faz a revelação dele, ou seja, domina uma parte da técnica; sabe exatamente qual "flash" deve utilizar para que a imagem saia boa, bem como sabe criticar uma revelação mal feita. $\mathrm{O}$ mesmo comportamento deve ser adotado para as tecnologias de ensino atuais: o docente deve aprender a manipular os programas que constróem páginas em HTML, sem necessariamente ter que dominar essa linguagem de programação; ao participar da confecção das páginas, terá plena consciência da organização das informações e da árvore de "links"; refletirá sobre essa organização e saberá analisar seu desempenho com os alunos. Saberá, sobretudo, formar uma equipe de produção (até mesmo terceirizada, se for o caso), com membros dedicados a atividades específicas que condizam com seu ponto de vista sobre esse processo de ensino-aprendizado. Enfim, o docente 
terá também que se submeter a um período de aprendizado (Sandholtz et al, 1997; Azevêdo, 2000), tal qual fez com as outras tecnologias educacionais (transparências, gravadores, videocassetes etc.).

As dificuldades técnicas não são inerentes aos docentes. $\mathrm{Na}$ aplicação dos "sites" aos alunos, vimos que alguns deles (poucos em relação ao desempenho das classes como um todo, como já comentamos) também possuem certa dificuldade no manejo do computador. Para esses alunos, foi difícil realizar os exercícios diretamente pela Internet; alguns entregaram por escrito, entrando no "site" somente para copiar as questões; outros nem acessaram o "site": tiraram cópia de impressões de outros colegas. Alguns optaram por digitar os exercícios no Microsoft Word ${ }^{\circledR}$, relatando que não acessaram o "site". Esse tipo de conduta foi aceita por nós sem provocar constrangimento nos estudantes, já que estávamos cientes de nossa deficiência curricular quanto a disciplinas de informática ou similares. Um dado importante é que alguns desses alunos manifestaram vontade de aprender a manipular o computador depois de ouvirem comentários dos colegas quanto aos "sites".

Dentre essas dificuldades do corpo discente, uma experiência que marcou quando da observação dos alunos foi com uma estudante que, depois de ter passado quase $1 \mathrm{~h}$ fazendo as questões, perdeu tudo. A estudante ficou desmotivada totalmente, entendendo ter sido sua a falha perante o computador, e não de má concepção da interface e de sistemas de segurança do "site". Esse fenômeno, em que o aluno se culpa de o computador ter falhado, ter dado um erro etc., foi citado em alguns trabalhos da literatura (Horvath \& Teles, 2000; 
Vieira, 2000). Nesses relatos, a experiência com o computador em sala de aula foi bastante frustrante, funcionando como um catalizador de aspectos negativos no processo de ensino-aprendizado. Em nosso trabalho, interpretamos esse fato como passageiro e momentâneo, pois, ao questionarmos a aluna depois de algum tempo do ocorrido, esta declarou estar utilizando o "site" normalmente, sem problemas.

Episódios dessa natureza nos serviram como prova de que o aluno de graduação em Odontologia está apto e consciente das vantagens de utilizar a Internet para o seu aprendizado. O questionário A.1 (Anexo A) já tinha nos indicado a vontade desses estudantes em ter o material didático "on line"; contudo não sabíamos qual seria a reação desse público diante das primeiras dificuldades que essa ferramenta acarreta. Vimos que os obstáculos técnicos e de infra-estrutura foram sendo sanados pelos próprios alunos, por intermédio de um processo adaptativo em que predominou, dentre outras ações, a substituição dos recursos de envio de respostas por outros mais práticos e seguros (como citamos ou pela impressão direta do conteúdo ou pelo envio utilizando o "e-mail" pessoal) e o acesso das páginas em casa sem estar conectado diretamente à Internet (diante das reclamações dos pais do alto custo que o acesso prolongado poderia acarretar nas contas telefônicas, os alunos passaram a dar "download" em todas as páginas e, depois, se desconectavam da Internet, podendo consultar os arquivos "baixados" diretamente pelo navegador sem utilizar a linha telefônica para isso). 
O questionário A.3, referente à enquete aos alunos de graduação que estavam fazendo o curso de Patologia Geral, revelou que 78\% do total de estudantes utilizaram o material disponível no "site" (Tabela 5.12, pág. 87). Grande parte acessou de casa o material, o que confirmou nossas expectativas do início do projeto de que teríamos que confeccionar páginas com recursos acessáveis à maioria dos usuários, sem muita utilização de "plug-ins"2 ou outras linguagens que complicassem o acesso. Em geral, os alunos aprovaram a apresentação das páginas. Nos comentários dos questionários, ficou patente a importância que os quesitos acessibilidade, legibilidade, composição e navegabilidade exercem sobre os usuários das páginas. Esses quesitos constituem os princípios básicos que uma página deve conter para se constituir um eficiente meio de comunicação (Lynch \& Horton, 2000; O’Dowd, 2000; Schultz et al., 2000; Melly, 2000; Nielsen, 2000). Os alunos fizeram comentários que abrangeram todos esses quesitos porque sentiram necessidade enquanto usuários, o que comprova a realidade desses princípios como sendo a base estrutural da mídia. Diante disso, o protocolo por nós elaborado procurou fundamentalmente atender a esses itens, adaptando-os à realidade da área médico-odontológica.

Tanto na questão sobre a apresentação das páginas quanto na da navegação, houve comentários que revelaram uma necessidade geral de impressão das páginas. Achamos que esse fato se deu, em primeiro lugar, pela exigência, em casa, de acessos rápidos à Internet devido a fatores ligados à linha telefônica (contas altas, ocupação da linha etc.), como já comentamos

\footnotetext{
2 "Plug-ins” são pequenos programas conectados às páginas em HTML destinados a executar determinadas ações, por exemplo, a execução de animações (Santos; Rodrigues, 1999).
} 
anteriormente. Em segundo lugar, o desejo de imprimir pode ser oriundo da dificuldade do aluno (e de muitas outras pessoas) em ler na tela do computador. Horvath \& Teles (2000) detectaram essa mesma necessidade quando suas páginas continham mais de 350 palavras. Depoimentos coletados dos alunos por esses autores indicaram que, além da dificuldade de leitura na tela, havia a necessidade de ler o material mais tarde, em casa, local onde não necessariamente teriam acesso à Internet. Essas razões também foram apontadas pelos alunos participantes do nosso projeto; uma brochura contendo todas as páginas do "site" de Patologia Geral ficou disponível no setor de "xerox" para toda a turma, iniciativa originada do próprio grupo de estudantes.

Pelo questionário A.1, vimos que grande parte dos alunos acessava de casa a Internet; portanto, a necessidade de impressão não advém só da carência do recurso tecnológico. Esse fenômeno nos leva a inferir que, provavelmente, os alunos de graduação em Odontologia estão ainda em transição quanto às novas mídias eletrônicas, principalmente quanto à sua linguagem. Já reforçamos que as dificuldades técnicas são praticamente contornadas pelos alunos; mas a linguagem em hipertexto, que exige um comportamento mais ativo e, ao mesmo tempo liberador, por parte do aluno, ainda não é natural no estudante. Azêvedo (2000) aponta um aspecto pedagógico importante quanto a isso: os alunos foram alfabetizados da forma tradicional, em que eram passivos diante da informação; a linguagem hipertextual é liberadora e, ao mesmo tempo, exige uma maior participação do aluno no processo de construção do conhecimento, o que, segundo o autor, gera certa ansiedade. Observamos um pouco dessa ansiedade 
em certos depoimentos em que o aluno revela haver muitos "links", necessitando de dados "mais específicos"; ou seja, há um certo desejo ainda da informação disponibilizada da forma linear, podendo, ao mesmo tempo, ser facilmente consultada e impressa. Nesse sentido, podemos dizer que o graduando ainda está em transição da linguagem linear para a hipertextual. A necessidade de impressão, as dificuldades de navegação e a constatação de que foram consultados somente os "links" indicados nos exercícios podem dar suporte a essa hipótese, a qual, ao nosso ver, mereceria um estudo mais específico.

Nessa transição, o docente assume um papel essencial. De detentor das informações e porta-voz delas, deve tornar-se um "estrategista da informação"3, ou seja, deve orientar os alunos quanto aos "links" mais adequados a seu aprendizado e estruturar estratégias de busca que balizem os objetivos programáticos disciplinares, sem prejuízo à liberdade de consulta dos alunos. Esse método poderia constituir, ao nosso ver, uma forma de "alfabetização hipertextual"'. Provavelmente as gerações futuras cheguem ao curso superior já formadas nessa linguagem, haja vista a grande quantidade de programas nacionais e internacionais dedicados à informatização da pré-escola (Sandholtz et al., 1997; Cooper, 2000).

O dado mais marcante da enquete realizada com os alunos que acessaram o "site" de Patologia Geral foi o fato de os estudantes detectarem um descompasso entre o conteúdo das aulas presenciais (em sala de aula) e o conteúdo do não-presencial (feito pela Internet). Como dissemos nos resultados,

\footnotetext{
${ }^{3}$ NOVELLI, M. D. Relatório da apresentação feita na $33^{\mathrm{a}}$ Reunião da Junta Diretiva do "Centro Interuniversitario de Desarollo" (CINDA). México, 11 e 12 de outubro de 2000.
} 
a pergunta sobre o conteúdo foi a mais comentada, havendo uma exigência por parte do corpo discente de maior aproximação entre os materiais disponibilizados. Interpretamos esse fato a partir da realidade institucional na qual foi concebido este trabalho: não tivemos a participação direta de todo o corpo docente para a confecção do material; este foi baseado na apostila utilizada pela disciplina, bem como no livro didático de um dos docentes (Guidugli-Neto, 1997). Os docentes que ministraram as aulas presenciais não transportaram seus conteúdos para o "site", o qual, muitas vezes, apresentou informações a mais ou a menos em relação às aulas. Isso atrapalhou os alunos, uma vez que estávamos aplicando uma forma mista de ensino (presencial e não-presencial), a qual, em vários momentos, revelou-se sem diálogo entre as duas sistemáticas adotadas. Devido a esse fato, acreditamos que qualquer iniciativa com recursos eletrônicos de ensino deve estar atrelada a um sistema de ensino como um todo, em que todas as suas partes componentes estejam voltadas para o mesmo objetivo. Essa postura é essencial, pois mais uma vez ficou patente que os alunos sentem e percebem claramente o grau de estruturação funcional e pedagógica de uma disciplina. A coesão e coerência entre os diferentes métodos de ensino devem ser profundamente analisadas e tidas como de importância fundamental.

Vale dizer que o descompasso entre o presencial e não-presencial foi devido também à dificuldade de atualização das informações na Internet à medida que as aulas eram ministradas. O ritmo de se fazer uma página para Internet é lento: demoramos, em média, 1,5h para fazer uma página sobre um tópico, contendo textos básicos e complementares e até 4 figuras ilustrativas (um 
tópico nunca esgota uma aula por inteiro; geralmente são apresentados, pelo menos, 3 tópicos diferentes em uma aula de Patologia Geral da FOUSP). Os alunos manifestaram em seus depoimentos a necessidade de terem acesso ao conteúdo em período bem anterior ao das provas, o que às vezes não foi possível.

Um aluno em transição em relação às interfaces computacionais e o papel do corpo docente na concepção de projetos com ensino eletrônico foram alguns pontos relevantes detectados no teste do "site" da Patologia Geral. Discutiremos agora outros aspectos que se destacaram no momento dos testes do "site" da Patologia Bucal.

Os exercícios do "site" da Patologia Bucal possuem uma característica peculiar: têm o objetivo precípuo de simular as aulas práticas da disciplina. Assim, estão disponíveis pelo menos três imagens diferentes de uma mesma lâmina, referentes a três aumentos distintos. $\mathrm{O}$ aluno, ao clicar no aumento, têm contato com essa imagem, a qual pode ser substituída por outra quando do clique sobre outro aumento. Dentro das imagens existem bolinhas que apontam estruturas morfológicas importantes para o reconhecimento da lesão; ao clicar sobre essas bolinhas, um pequeno texto explicativo da estrutura surge no canto inferior da tela. O estudante é instigado a explorar essas imagens por intermédio da pergunta do exercício; este visa fazer com que o aluno memorize a estrutura morfológica e compare o quadro histológico como um todo com outros quadros de lesões de um mesmo grupo de patologias, as quais são devidamente "linkadas" ao exercício. Com esse estudo morfológico comparativo (o qual envolve também tecidos 
normais), incrementa-se o nível de informação e de conhecimento a ser consolidado pelo estudante.

A diferença desse protótipo de microscópio virtual em relação à sistemática tradicional de exame ao microscópio reside, pelo menos, em dois pontos. Primeiramente, o processo analítico exploratório permitido pelos microscópios de luz tradicionais (com movimentos livres do "charriot", mudanças da intensidade de luz e de foco etc.) leva a um nível de informação mais específico para o aluno, na medida em que permite uma calibragem pessoal de visualização da imagem; além disso, a orientação quanto à interpretação das estruturas é dada pelo docente e por tutores que auxiliam individualmente no estudo. Esse processo exploratório individual não está totalmente simulado no "site", uma vez que o recurso criado não permite, por exemplo, ajustes do foco e da luz. Além disso, as imagens são estanques, não havendo plena liberdade de se visualizarem maiores aumentos em regiões selecionadas pelo usuário, o que torna o estudo morfológico mais pontual. Já existem projetos que procuram desenvolver a interatividade nos microscópios virtuais, com aplicação na telepatologia, como é o caso dos trabalhos de Landman et al. (2000).

Um segundo ponto, este favorecedor do método virtual, é que o aluno pode ter contato, ao mesmo tempo, com a estrutura morfológica, o ambiente clínico e a base teórica que subjaz ao caso analisado. A rede de "links" estruturada nos exercícios promove esse intercâmbio, tornando a lâmina autoexplicativa e inserida em um contexto de patologia mais ampliado. Em algumas explicações de estruturas morfológicas, por exemplo, existem "links" que 
remetem ao "site" da Patologia Geral, no qual o aluno encontra outras imagens envolvendo a mesma estrutura. Além disso, o processo patológico é representado tanto pela morfologia presente na lâmina quanto por radiografias, tomografias, imagens intrabucais etc., acessadas pelos alunos também via "links" para o caso clínico completo ou para outros casos da mesma lesão. Ou seja, o aluno tem disponível um amplo banco de dados em que um estudo comparativo e extrapolativo é factível totalmente.

Nos laboratórios de aulas práticas esse nível de interação fica dificultado principalmente pelo grande número de alunos. Essa atividade interativa exige uma certa dedicação individual, tanto do aluno quanto da monitoração feita pelo docente, uma vez que a carga de informações e relações entre os conceitos é altíssima.

Esse problema de grande audiência para poucos tutores também é observado na Internet. Na aplicação dos exercícios de Patologia Bucal (e também na dos exercícios de Patologia Geral), vários alunos tiveram dúvidas inerentes a áreas como Radiologia, Semiologia e Cirurgia, cujas informações estão atreladas diretamente ao diagnóstico do caso clínico. Esses alunos não tinham cursado ainda essas disciplinas, o que foi um fator complicador para a execução dos exercícios. Grande quantidade de "e-mails" foi recebida nessa época, os quais nem sempre foram respondidos em tempo hábil. Apesar dessas inquietações, os alunos acharam interessante a intersecção com disciplinas relacionadas ao processo diagnóstico e ao tratamento cirúrgico, pois depreenderam uma aplicação prática e abrangente do dia-a-dia do profissional da área odontológica. 
Pensamos, a princípio, diante dessas dificuldades, principalmente de nossa parte, restrita à operacionalidade do "site" e ao retorno das informações, em elaborar exercícios mais voltados especificamente à Patologia Bucal, ou seja, à análise morfológica das lesões, ao sistema classificatório das doenças bucais e ao seu significado clínico. Contudo, achamos conveniente manter a primeira estratégia, que explorava, além desses temas, fatores ligados a outras disciplinas. Um dos motivos que nos levou a tomar essa decisão foi o apresentado no artigo de Radford (1994), em que o autor considera o sucesso da Open University como sendo em decorrência, dentre outros fatores, do cuidado na elaboração de processos avaliativos. O autor comenta que a credibilidade dos cursos foi entendida pelos alunos com base principalmente no nível informacional do conteúdo e da avaliação. Por corroborarmos com essa opinião do autor, optamos pela estruturação de exercícios com mais interdisciplinaridade, sem menosprezar a capacidade dedutiva e intelectual dos alunos, e sim investindo no contrário: no desenvolvimento dessa capacidade. Este ficou patente ao recebermos os exercícios prontos. O envolvimento dos estudantes foi bastante intenso. Como dissemos nos resultados, os alunos demoraram, no mínimo, 3 horas para a elaboração das respostas; no Laboratório de Informática Dedicado à Odontologia, vimos alunos gastando até 7 horas. As respostas, em geral, foram bastante longas e elaboradas, indicando um processo de interpretação por parte do aluno e não somente de reprodução de algo já pronto.

Acreditamos que o alto nível das respostas deu-se principalmente pela possibilidade que o estudante teve de fazer os exercícios segundo seu ritmo 
pessoal. A forma variada de envio das respostas (todas de uma vez, todas juntas, uma em cada dia etc.) e a grande variabilidade do horário de envio dos "e-mails" indicaram a existência desse sistema individual de estudo, o qual pode ser bastante interessante para se atingir objetivos pedagógicos que visam uma aprendizado por intermédio da criação, e não somente da reprodução.

Apesar das dificuldades técnicas e institucionais enfrentadas (falta de sistema de segurança contra perda de informações nas respostas dos alunos; ausência de mais docentes para o retorno dos "e-mails"; atrasos na atualização do "site"; ausência de suporte curricular de disciplinas afins, para a criação de um hipertexto mais rico etc.), o “site” da Patologia Bucal obteve aprovação geral pelos graduandos, a qual foi detectada pelo questionário A.2 (Anexo A). Além dessas opiniões, o fato de termos recebido os exercícios da maioria dos participantes diretamente pela Internet nos garantiu que essa sistemática de comunicação entre aluno e professor é bastante viável e construtiva.

A questão do questionário A.2 (Anexo A) mais comentada foi a relacionada à navegação. A estrutura do microscópio virtual por nós elaborada demandou, no início, a abertura de um grande número de janelas, a qual tornouse de difícil gerenciamento por parte dos alunos. Futuramente, o ideal é conceber um projeto de microscópio que funcione como um "applet", um pequeno aplicativo conectado à página da Internet que funciona com certa independência da linguagem HTML (Santos \& Rodrigues, 1999). Por intermédio desse recurso, não seria necessária a abertura de muitas janelas nem a utilização de vários 
"frames", pois todos os elementos que compõem o microscópio ficariam contidos em uma mesma janela em um só "frame".

Um dado interessante apontado no questionário foram os "links" para a Patologia Geral. Os alunos aprovaram essa iniciativa e entenderam sua dimensão; contudo, acharam que seria necessária a criação de "links" explicativos. Entendemos por esses depoimentos que há necessidade de uma breve contextualização antes de se adentrar à Patologia Geral. Essa manifestação é perfeitamente justificada, haja vista a grande diferença de ambientação que existe entre um "site" e outro. Além de diferenças no "layout", já comentadas por nós nesta discussão, existem diferenças marcantes entre a forma de abordagem dos conceitos e da aplicação dos mesmos nos diferentes tópicos. Ou seja, as disciplinas são bastante diferentes sob o ponto de vista pedagógico e de estratégia de abordagem, o que ficou refletido na confecção dos "sites". Os alunos, assim, sentiram a necessidade de uma ponte que lhes explicasse e limitasse essas diferenças, para poderem sentir a funcionalidade dessa interdisciplinaridade em seu processo de aprendizado. Acreditamos que essa ponte deva ser feita com os docentes de ambas as disciplinas, tomando como base uma estratégia pedagógica comum.

Tanto no "site" da Patologia Geral quanto no da Bucal, os alunos querem mais conteúdo, mais imagens e mais textos complementares. Esse dado indica que o corpo discente quer continuar investindo na consulta dos "sites". Vale dizer que ambos os materiais são bastante completos (todo o conteúdo da Patologia Geral está inserido e 2/3 do programa da Patologia Bucal está 
disponível), mas estão atendendo às necessidades mínimas de aprendizado dos alunos considerando-se o amplo potencial de acesso às informações que a Internet possibilita e que o aluno deseja.

O impacto do "site" da Patologia Bucal sobre a comunidade odontológica foi bastante significativo. Sem qualquer estímulo adicional que não o da presença do "link" no "site", a quantidade de dentistas e estudantes cadastrados (60, no total, em um período de mais ou menos 6 meses) foi sugestiva do alto índice de acessos por esses profissionais. Acreditamos que esse sucesso seja decorrente principalmente da qualidade do conteúdo disponibilizado: são casos clínicos raros ou com terapêutica peculiar, que suscitam a curiosidade dos especialistas da área. Além disso, o "site" retrata um serviço de anatomopatologia de doenças bucais bastante importante para o Brasil, por possuir um acervo com mais de 34000 biópsias e por sua grande contribuição científica. Pelos cadastros, está patente que o "site" está sendo consultado praticamente em todo o Brasil (Tabela 5.10, pág. 83), o que enfatiza o seu papel como difusor de informações importantes para a comunidade odontológica de uma forma democrática. Esse resultado nos obriga a refletir sobre o papel educacional que esse veículo tem desempenhado, tornando-nos responsáveis por garantir o acesso a dados sobre a população brasileira e, principalmente, sobre a forma como as doenças bucais agem sobre ela, bem como sobre seu processo diagnóstico. Encaramos esse aspecto do "site" como um dos pontos mais importantes da educação à distância e que já comentamos aqui: a possibilidade de atualização para pessoas distantes dos grandes centros detentores da infra-estrutura de pesquisa e ensino. Vale dizer que 
conseguimos difundir a existência do "site" por intermédio da lista de "e-mails" da Sociedade Brasileira de Estomatologia (SOBElist), entidade de classe mais atuante no Brasil no tocante a temas envolvendo a Estomatologia. Observamos que os estudantes e profissionais cadastrados não necessariamente fazem parte da SOBElist, o que indica que houve uma comunicação entre os profissionais da área quanto à existência de nosso material. Ou seja, a difusão está acontecendo automaticamente, sem qualquer estímulo de propaganda que não $\mathrm{o}$ da comunicação "boca-a-boca" entre os profissionais.

Diante dessa aceitação do nosso material na comunidade odontológica, achamos por bem, futuramente, planejar estratégias de abordagem mais eficazes que visem maior interatividade entre o nosso núcleo de pesquisa e os usuários do "site", alimentando esse potencial de educação continuada que ele possui. Alguns recursos de interatividade presentes no "site" já estão funcionando, como os formulários de enquete acerca da opinião do usuário sobre o caso clínico acessado ou o pequeno teste que solicita o diagnóstico que o usuário emitiria. Até agora, somente 33 opiniões foram coletadas, a maioria delas emitidas por estudantes. Julgamos ser necessário o incremento desse recurso, valendo-nos de estratégias mais lúdicas, tais como testes de avaliação de conhecimento direcionados ao profissional, com respostas imediatas, jogos com os casos clínicos, confronto entre diferentes posturas diagnósticas etc., bem como a publicação do retorno dos usuários, criando-se grupos de discussão e outras formas de interação. Além disso, seriam interessantes recursos que permitissem a publicação dos casos clínicos dos usuários, formando-se um grande banco de 
dados. No Brasil ainda não vimos um "site" de Patologia Bucal com essas características, mas nos Estados Unidos alguns já estão se formando na área médica, como o do Centro Médico da Universidade de Pittsburgh (Landman et al., 2000).

O "site" da Patologia Bucal e o da Geral foram testados com os alunos de graduação da Universidade de São Paulo. Já o "site” do curso de introdução à técnica cirúrgica foi avaliado tendo-se como público estudantes de graduação em Odontologia de outras universidades brasileiras (Tabela 5.1, pág.63) e que estavam cursando diferentes semestres. Um dos objetivos desse teste foi verificar a influência de uma forma de transmissão de informações totalmente homogênea (utilizando-se circuito interno de TV e computadores), em que todos os alunos acessam o mesmo nível de informação, sobre uma população heterogênea quanto à sua formação instrucional. A motivação desses alunos ficou garantida pelo fato de se tratar de um curso pago, em que todos estavam ali devido à vontade de aprender.

Esse curso de técnica cirúrgica já vinha sendo aplicado à graduação da FOUSP da forma tradicional, sem a presença de computadores, mas com a utilização de circuito interno de TV e câmeras. O docente ministrante já tinha pleno conhecimento das principais dificuldades dos alunos e dos momentos do curso mais críticos quanto à possibilidade de possíveis acidentes que envolvessem ferimentos e ou contaminações, já que os instrumentos do curso envolvem uma perna de frango fresca e instrumental cirúrgico. Assim, a equipe participante 
estava ciente dessas dificuldades, as quais se potencializam considerando-se que se trata de uma atividade não-presencial.

O curso foi estruturado para simular uma aula de técnica cirúrgica em que o professor estivesse monitorando as ações dos alunos por intermédio de microcâmeras. Foram, assim, colocadas 10 microcâmeras próximas à área de trabalho do aluno, cuja imagem era diretamente transmitida a uma mesa controladora localizada à frente do laboratório, em que se posicionavam o docente responsável e seus ajudantes. As interferências destes nos trabalhos dos cursantes eram feitas somente quando se detectavam falhas graves nas ações executadas pelos alunos, bem como nos momentos críticos do curso, já comentados. Assim, não houve a total ausência do professor na sala, mas sim a sua transformação de agente principal do curso para mais um instrumento de consulta.

O “agente principal" do curso passou a ser o "site". Os alunos eram brevemente orientados, no início, a consultar o conteúdo, familiarizando-se com a forma de funcionamento do "software" TopClass ${ }^{\circledR}$. Depois, eram imediatamente instigados a iniciar suas atividades, consultando somente o "site". Este continha cada um dos passos do curso, estando estruturado como se fosse uma receita. A técnica era bem detalhada e ilustrada por imagens. Observamos que logo depois da orientação, os alunos optaram por navegar brevemente pelas páginas e "links", inteirando-se do curso como um todo; só depois começaram os primeiros passos da técnica, a qual envolvia a conferência do material solicitado, a vestimenta de avental, óculos de proteção, máscara e luvas e a delimitação da área 
de trabalho. Nesse momento, passamos a detectar os primeiros sinais de dificuldade de utilização do computador, uma vez que este estava disponível para cada dupla de alunos, localizando-se na parte central da bancada. Para alguns estudantes, o acesso ao "mouse" ficou dificultado diante do uso de luvas e da distância entre este e sua área de trabalho, sendo flagradas algumas posições antiergonômicas. Estas, ao nosso ver, não constituíram empecilho para o curso, pois nenhum aluno reclamou dessa falha de infra-estrutura durante o curso e nos depoimentos do questionário A.4 (Anexo A). Porém, trata-se de um problema de crucial importância a ser considerado em cursos a distância envolvendo atividades manuais, já apontado por Schultz et al. (2000).

As dificuldades no manejo do computador foram interpretadas por nós, a partir dos depoimentos do questionário, como sendo não pertencentes ao campo da informática, da Internet ou das interfaces eletrônicas. Vimos que os alunos, na verdade, tiveram dificuldades em interpretar o texto e as imagens contidas no "site", achando o computador "difícil". Por outro lado, declararam que foi fácil manipular a peça animal e o computador ao mesmo tempo, pois julgaram que este estava com o conteúdo bem dividido, não sendo tão necessária a movimentação de barras de rolagem no computador, o que demandaria a utilização do "mouse" toda hora. Esse aspecto ligado ao "layout" de páginas de curso em que o aluno estará com as mãos ocupadas deve ser bem equacionado e merece maiores estudos, os quais devem visar, dentre outras medidas, a fácil leitura do monitor de pontos distantes da tela sem estar necessariamente 
posicionado centralmente a esta e o uso de "mouse" o mais restrito possível. O teclado não foi acionado nenhuma vez, já que as páginas não o solicitaram.

Observamos que cada participante fez o curso com seu ritmo pessoal. Nem todos iniciaram a técnica ao mesmo tempo e, durante todo o período de aprendizado, notoram-se oscilações nesse ritmo. Estas foram devidas principalmente às dificuldades encontradas em determinados passos, as quais não foram necessariamente as mesmas para todos. A observação desse comportamento é de crucial importância para o estabelecimento de novas diretrizes pedagógicas, levando-se em conta que o aprendizado manual é diferente do intelectual.

Vimos que todos os alunos fizeram todos os passos da técnica e chegaram ao produto final, cuja qualidade variou bastante. Concluímos que houve uma grande assimilação da filosofia da técnica cirúrgica, de seus objetivos e dos detalhes que levam a uma boa manipulação do instrumental, mas o produto final deixou a desejar. Nesse ínterim, acreditamos que nada substitui a intervenção direta do professor no trabalho do aluno; o curso a distância serve como um introdutor da técnica, mas o aluno deve entrar em contato com um produto final considerado ideal. Uma outra vantagem desse material "on line" reside no fato de que há possibilidade de reprodução da atividade em casa ou na própria instituição, fora dos horários das aulas.

Esse resultado de que o aluno assimilou a filosofia mas não produziu a contento deve também merecer reflexões sérias por parte do grupo docente. $\mathrm{O}$ estudante exercitou o tempo todo sua capacidade interpretativa, o que atinge uma 
parte de um programa pedagógico que vise a construção do conhecimento pelo aluno. Contudo, acreditamos que este deve estar ciente dos resultados da boa execução de uma técnica, e daí a introdução de formas mistas de aprendizado (presencial e não-presencial) talvez seja mais adequada para o público de estudantes da Odontologia. $\mathrm{O}$ não-presencial poderia funcionar como um recurso de reforço e treinamento do aluno, sendo solicitados outros níveis de aplicação técnica, por exemplo, com o professor tirando as dúvidas a distância. As informações essenciais, os modelos ideais de produção manual seriam transmitidos diretamente pelo professor nos laboratórios.

Os recursos de comunicação utilizados no curso foram avaliados pelos alunos. Notamos que a média mais baixa foi atribuída à televisão. Interpretamos esse resultado entendendo que a televisão estava funcionando ali como uma forma de se homogeneizarem as informações, já que todos os alunos veriam seus próprios trabalhos e os dos colegas; contudo, esse recurso não funcionou adequadamente, pois o professor não exerceu o papel de mediador dessas imagens, interpretando-as junto com os alunos. Além disso, o ritmo pessoal de cada um deles fez com que se desinteressassem por esse veículo, já que não necessariamente o que estava na tela correspondia ao passo em que se encontravam. A TV, por outro lado, atendeu a uma necessidade essencial: foi a forma de que o docente dispôs de apontar informações básicas e relevantes que não ficaram claras no "site" a todos os alunos de uma só vez, o que garantiu que todos os estudantes, mesmo não sentindo falta do conhecimento apontado na TV, inteirassem-se dele. Esse aspecto foi de fundamental importância, já que não 
tínhamos conhecimento da bagagem intelectual e da capacidade motora dos alunos, pois estes não pertenciam ao corpo discente da nossa faculdade.

O computador foi utilizado pelos alunos durante todo o curso, já que continha o material de orientação. $O$ interessante no curso foi o papel que o professor assumiu uma vez sendo o computador a fonte das informações. $\mathrm{O}$ docente serviu como um instrumento de complementação do aprendizado, exercendo funções como tirador de dúvidas e de aperfeiçoamento da atividade manual, principalmente no tocante ao manejo dos instrumentais. Exerceu, assim, uma função mais de tutoria do que propriamente de centralizador do processo de ensino-aprendizado. Vale dizer que alguns alunos sentiram falta do método tradicional, em que o docente apresenta a técnica e o aluno a copia. Contudo, esses comentários não foram a da maioria, o que denota um preparo inerente aos jovens a receber novas alternativas de ensino.

Outro ponto importante desse curso foi a aplicação de um "software" para ensino a distância em uma população de estudantes de Odontologia exercendo atividades manuais. Esse "software" é amplamente difundido nos Estados Unidos, sendo aplicado em várias universidades, empresas e outras instituições de ensino (Santos et al., 2000). Caracteriza-se por permitir o amplo gerenciamento e controle das ações dos alunos e dos professores, garantindo o cumprimento adequado das fases do curso. Não foi enfoque deste trabalho uma análise aprofundada desse programa e de seu impacto sobre o corpo discente. Pudemos observar, contudo, que a transposição do nosso material para seu ambiente operacional — o "site" foi construído, inicialmente, para ser acessado 
utilizando somente os navegadores, sem o apoio de gerenciadores de ensino a distância — foi dificultosa, uma vez que tivemos que adaptar toda a rede de "links" criada. No TopClass ${ }^{\circledR}$ a liberdade de navegação é mais restrita. Acreditamos que essa característica não seja exclusiva desse "software", pois a maioria dos programas para ensino a distância estão baseados em módulos fixos, a serem cumpridos segundo uma sistemática prévia. Nem sempre essa característica foi benéfica para nosso curso, já que muitas vezes era necessária a retomada de pontos já comentados em módulos anteriores. No nosso ver, os cursos a distância que utilizam esses meios de gerenciamento devem ter disponibilizado aos alunos todo o material didático do curso, na qual a navegação é livre. Os módulos a serem criados nos gerenciadores devem visar a exploração desse conteúdo, orientando e sugerindo possibilidades de navegação. Assim, a fixidez dos gerenciadores atende uma parte do programa pedagógico que necessita de certa "disciplina” de acesso aos conteúdos (Gomez, 2000); todo o material didático, estando fora desse sistema, realiza a contrapartida do processo de ensino-aprendizado em que o aluno é construtor de seu conhecimento e, portanto, ativo na exploração das informações.

Os resultados aqui discutidos derivados dos três "sites" retratam as diferentes formas de se conceberem páginas para Internet direcionadas à educação. Além disso, refletem as reações e os comportamentos dos estudantes de Odontologia em relação a essa mídia, aspecto de grande interesse para uma área em que parte de sua fundamentação está baseada em práticas manuais. Assim, o "site" da Patologia Geral é um livro eletrônico básico, que se articula 
com um banco de dados aplicado à área de odontologia envolvendo diagnóstico — "site" da Patologia Bucal — e à área da odontologia operacional, prática — "site" do curso de introdução à técnica cirúrgica. Este trabalho visou, sobretudo, entender a relação da Internet nesses três campos de uma mesma ciência e analisar a interdisciplinaridade possível estabelecida pela mídia entre eles.

Quanto a essa última questão — a da interdisciplinaridade — entendíamos que, pelo fato de estarmos produzindo um material baseado em uma linguagem hipertextual, em que essencialmente são estabelecidas relações e conexões, potencialmente já estaríamos produzindo uma forma de interdisciplinaridade. Bastariam "links" entre os "sites" para que essa intenção pedagógica se concretizasse. Vimos, contudo, que isso não aconteceu. Os alunos que acessaram o "site" de Patologia Geral não conseguiram transportar os conceitos dos processos gerais para os casos clínicos da Patologia Bucal; o mesmo aconteceu com os alunos que cursavam essa última disciplina, os quais não entenderam o significado da retomada da matéria vista no semestre anterior no contexto de aprendizado em que se encontravam. Esses estudantes, por outro lado, aprovaram essa iniciativa de conexão entre as disciplinas. Já no curso de introdução à técnica cirúrgica, os participantes acessaram pouco ou nada do conteúdo teórico básico, referente a noções de inflamação e reparação dos tecidos bucais, não tendo sido feita nenhuma alusão a esse conteúdo nos questionários. Concluímos, assim, que falhamos em produzir concretamente uma perspectiva interdisciplinar neste trabalho. 
Algumas interpretações quanto a essa falha podem ser delineadas com base em Lenoir (2000). O autor distingue três tipos de interdisciplinaridade: 1) Interdisciplinaridade curricular: primeiro nível de interdisciplinaridade; consiste no estabelecimento de ligações de interdependência, de convergência e de complementaridade entre as diferentes disciplinas; visa o estabelecimento de uma linguagem comum, de técnicas comuns, de objetivos específicos comuns, mantendo-se, ao mesmo tempo, as especificidades disciplinares. 2) Interdisciplinaridade didática: segundo nível de interdisciplinaridade: tem função mediadora entre os planos curriculares e pedagógicos; articula os conhecimentos a serem ensinados e sua inserção nas situações de aprendizagem. 3) Interdisciplinaridade pedagógica: terceiro nível de interdiciplinaridade; caracteriza a atualização em sala de aula da interdisciplinaridade didática; assegura a colocação de um modelo didático interdisciplinar.

Podemos, em uma primeira instância, dizer que realizamos somente a interdisciplinaridade didática, em que se estruturam as relações entre os diferentes conhecimentos. Mas, se entendermos o processo interdisciplinar como um sistema, cujos níveis se articulam e se interdependem, podemos dizer que não realizamos nem esse tipo de interdisciplinaridade. Não dispomos de um plano curricular baseado nas relações entre diferentes disciplinas, nem tampouco um ambiente pedagógico que garante a execução e concretitude desse modelo; portanto, não temos contexto para produzir a interdisciplinaridade didática. Sem a reflexão e o planejamento desses modelos em âmbito institucional, nunca se atingirá essa forma de ensino-aprendizagem. A Internet garante tecnicamente 
uma base bastante promissora em termos de comunicação para que esses modelos possam ser colocados em prática; contudo, valer-se somente dela não é o bastante.

Projetando nosso trabalho para a FOUSP como um todo, vemos que se trata somente de um início, com caráter embrionário, da instauração de modelos de ensino não-presenciais. Desenvolvemos um trabalho isolado das demais disciplinas dessa escola, as quais ainda não se posicionaram quanto à modalidade de ensino a distância. Acreditamos que esse comportamento seja comum a maioria das unidades de ensino da Universidade de São Paulo, ou seja, o ensino a distância está sendo feito, mas graças a grupos pequenos de docentes, sem haver uma política institucional que norteie a criação de ferramentas desse tipo para toda a unidade (Novelli et al., 2001). Um dos caminhos a ser seguido seria justamente incentivar os docentes a "linkar" seus materiais no "site" de sua unidade, iniciando o protótipo de uma Universidade virtual por intermédio de uma diretriz comum.

Como resultado final deste trabalho, foi elaborado um protocolo de criação de materiais didáticos “on line” dedicados à área médico-odontológica. Esse protocolo constitui um resumo dos princípios inerentes ao processo técnico de criação de páginas para Internet, com peculiaridades que remetem diretamente à área médico-odontológica, os quais foram amplamente discutidos aqui. Esses quesitos e normativas foram pautados principalmente com base na infra-estrutura que a FOUSP tem disponível atualmente para essas iniciativas, bem como na forma como os alunos encararam e manipularam os materiais criados. Assim, 
entendemos esse protocolo como um guia para os docentes e técnicos que queiram desenvolver trabalhos nessa linha, devendo ainda merecer maiores testes e análises, principalmente no que concerne ao estudo dos modelos pedagógicos atuais. 
CONCLUSÕES 


\section{CONCLUSÕES}

7.1 Os alunos de graduação em Odontologia dos cursos diurno e noturno de 2000, cursantes das disciplinas de Patologia da FOUSP, estão aptos tecnicamente e desejam ser submetidos a um sistemática de ensino a distância, utilizando a Internet como veículo de transmissão das informações.

7.2 Os bancos de dados gerados para as disciplinas de Patologia Geral e Patologia Bucal constituem um acervo digital que retrata o arsenal didático disponível para a ministração desses conhecimentos na FOUSP, bem como constitui um indicador do nível de abordagem e das atividades dos docentes dessa escola.

7.3 Os "sites" gerados (Patologia Geral, Patologia Bucal e Introdução à técnica cirúrgica) estavam condizentes, em termos de "layout" e quantidade de informações, com a proposta pedagógica direcionada a cada um deles, quais sejam, ser um livro eletrônico (Patologia Geral), ser um banco de dados de casos clínicos (Patologia Bucal) e ser um curso sobre técnica cirúrgica, com atividades manuais (Introdução à técnica cirúrgica), abordando grande parte do plano curricular da Odontologia.

7.4 Os alunos aprovaram os "sites" e a iniciativa de introdução de ensino a distância na FOUSP. Demonstraram facilidade no manejo das interfaces 
computacionais e grande capacidade adaptativa no tocante às falhas no suporte tecnológico disponibilizado.

7.5 Os estudantes revelaram estar em transição do ensino presencial para o nãopresencial, principalmente em relação às estruturas hipertextuais.

7.6 A estrutura tecnológica disponível na FOUSP não foi suficiente em muitos momentos, devendo merecer reflexões mais aprofundadas ao se instituírem projetos de ensino a distância.

7.7 A maioria dos alunos acessou os "sites" diretamente de suas casas, o que supriu, em parte, as deficiências tecnológicas da instituição. Contudo, os gastos com o uso dessa infra-estrutura domiciliar gerou alguns conflitos familiares.

7.8 Houve um descompasso entre o conteúdo ministrado nas salas de aula e o veiculado pela Internet, devido à ausência de uma sistemática eficiente de atualização do "site" compatível com as aulas presenciais, bem como à falta de atuação conjunta de todos os componentes das disciplinas na confecção do material "on line".

7.9 A proposta de interdisciplinaridade utilizando somente a estrutura dos "sites" não se concretizou. Maiores reflexões sobre essa falha merecem ser feitas, principalmente considerando-se o "status" atual de organização das disciplinas.

7.10 O protocolo preliminar estabelecido para a produção de material didático “on line" é fruto das inovações e adaptações deste projeto, devendo ser 
melhor analisado e testado, principalmente no tocante ao seu impacto em relação às estratégias pedagógicas mais recentes.

7.11 A mudança de paradigma quanto ao ensino para a graduação em Odontologia é viável considerando-se o preparo inerente dos jovens às novas tecnologias de aprendizado. 


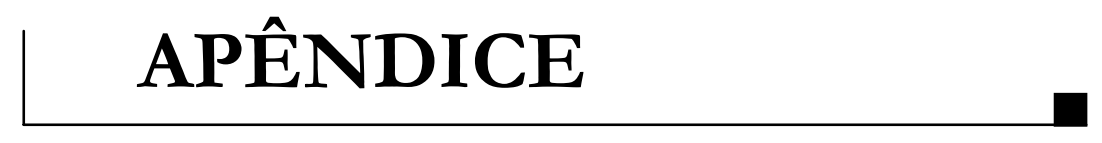




\section{APÊNDICE}

Instruções para acessar o conteúdo do CD-ROM:

1. Introduza o CD-ROM no "drive" do computador e acesse o Windows Explorer ${ }^{\circledR}$.

2. Nesse programa, ao clicar no CD-ROM, aparecerão os seguintes diretórios, referentes a cada um dos "sites" gerados neste trabalho: Patologia Geral, Patologia Bucal, Técnica Cirúrgica.

3. Ao abrir o diretório desejado, clique duas vezes sobre o arquivo index.html. Será ativado seu navegador de WEB, aparecendo a primeira página do "site" acessado.

4. Navegue normalmente, como se estivesse conectado à Internet. Os arquivos serão acionados diretamente do CD-ROM.

5. Os formulários de preenchimento estão programados para ativar o sistema de e-mail do seu navegador assim que a tecla "Enviar" é clicada. Para enviar mensagens por esse sistema, será necessário ficar "on line". 


\section{ANEXO A}

Questionários e Ficha de observações 


\section{ANEXO A}

QUESTIONÁRIO A.1 - Entregue aos alunos de $2^{\circ}$ e $3^{\circ}$ anos graduação dos cursos diurno e noturno para conbecimento da população-alvo

\section{UNIVERSIDADE DE SÃO PAULO \\ FACULDADE DE ODONTOLOGIA \\ DISCIPLINA DE PATOLOGIA BUCAL E PATOLOGIA GERAL}

1) Sexo:

$\square$ Masculino $\square$ Feminino

2) Idade:

3) Você possui computador em casa?

Sim $\quad \square$ Não

4) Quais os programas ("softwares") que você utiliza?
Word
Photo Shop
Adobe Page Mill
Power Point
Corel Draw
Front Page
Excel
Photo Styler
Hot dog

Outros

5) Você utiliza a Internet? Com que freqüência?

Sim, todos os dias

Sim, duas vezes por semana

Sim, três vezes por semana

Sim, só aos fins de semana

Sim, uma vez por semana

$\square$ Não

6) Se você NÃO UTILIZA a Internet: quais os motivos?

$\square$ Não sei mexer

$\square$ Não gosto

$\square$ Não tenho em casa $\quad \square$ Outros

7) Se você UTILIZA a Internet: para quê?

$\neg$ Sistema de "e-mails"

Discussão em grupos ("chats")

Busca bibliográfica

Consulta de "sites":
$\square$ relacionados à Odontologia
relacionados à área médica
$\square$ de entretenimento
para compra e venda de produtos
Outros

8) Você gostaria de utilizar a Internet para acessar as matérias do seu curso de Odontologia?

$\square$ Sim

Favor escrever o seu nome completo e seu "e-mail", se tiver:

Nome:

E-mail: 
QUESTIONÁRIO A.2 - Entregue aos alunos de graduação do curso do noturno, os quais fizeram os exercicios de Patologia Bucal pela Internet

\section{EXERCÍCIOS PELA INTERNET}

Você realizou exercício de Patologia Bucal utilizando a Internet como veículo de acesso e transmissão das informações. Essa iniciativa faz parte de um projeto de tese de Doutoramento. Para obtenção de dados objetivos, necessitamos que você, como usuário do site, informe-nos sobre suas impressões. Obrigada por participar. (Não precisa se identificar).

O que você mudaria na apresentação das páginas ("layout")?

Oque você mudaria no sistema de navegação ("links")?

O que você mudaria no conteúdo?

O que você mudaria nas imagens?

O que você mudaria nos textos?

Onde você realizou os exercícios (na sua casa, na faculdade, na sala pró-aluno etc.)?

\section{Comentários.}


QUESTIONÁRIO A.3 - Entregue aos alunos de graduação do curso diurno, os quais acessaram as páginas de Patologia Geral disponiveis na Internet

\section{SITE DE PATOLOGIA GERAL}

A confecção do site de Patologia Geral faz parte de um projeto de tese de Doutoramento. Precisamos da sua opinião para continuar nossos projetos. Por favor, responda as questões abaixo. Não precisa se identificar. Muito obrigada por participar.

Você acessou o site de patologia geral?

O que você mudaria na apresentação das páginas ("layout")?

O que você mudaria no sistema de navegação ("links")?

O que você mudaria no conteúdo?

O que você mudaria nas imagens?

O que você mudaria nos textos?

Onde você acessou o site (na sua casa, na faculdade, na sala pró-aluno etc.)?

Comentários e ou sugestões. 
QUESTIONÁRIO A.4 - Entregue aos alunos de graduação que participaram do curso de introdução à técnica cirúrgica, ministrado do XXV Congresso Universitário Brasileiro

$$
\text { de Odontologia (CUBO) }
$$

UNIVERSIDADE DE SÃO PAULO - FACULDADE DE ODONTOLOGIA
XXV CONGRESSO UNIVERSITÁRIO BRASILEIRO DE ODONTOLOGIA
CURSO “ANESTESIA, CORTE E SUTURA" (INTRODUÇÃO À TÉCNICA CIRÚRGICA)
Obrigado por participar de nosso curso. Para aprimoramento do mesmo, necessitamos da
sua opinião.
Idade_Sexo__nstituição_

Você acessou o site do curso antes de fazê-lo agora (em casa, por exemplo)? Foi fácil para você realizar a técnica cirúrgica e consultar o site ao mesmo tempo? Sim ou Não ?Por quê?

3) Atribua valores de 0 a 10 para os recursos de transmissão das informações do curso:

pela televisão:

pelo computador:

pelo professor:

4) Em qual (is) momento (s) do curso você acha que cada um desses recursos foi bastante importante para o entendimento da técnica cirúrgica?

Televisão:

Computador:

Professor:

5) Cite 3 pontos positivos e 3 negativos do curso.

Positivos:

1.

2.

3.

Negativos:

1. .

2. .

3. .

Comentários e ou sugestões. 
FORMULÁRIO A.5 - Preenchido pelo examinador durante a observação dos alunos ao acessarem as páginas

\section{CRITÉRIO DE ANÁLISE DOS USUÁRIOS E DE SUA PRODUÇÃO QUANDO DO ACESSO ÀS PÁGINAS DA WEB}

Disciplina: $\square$ Patologia Geral

Patologia Bucal

Data:

Nome do aluno:

Início:

h Término:

e-mail:

Tempo de adaptação à interface:

h

Principais perguntas: $\square$ Sobre o mecanismo de consulta ( Sobre o sistema de janelas (

Sobre o sistema de preenchimento do exercício

Sobre as questões em si

Dificuldades: $\square$ De acesso ao exercício conteúdo $\mathrm{X})$ $x)$ De entendimento da proposta dos exercícios
Grau de curiosidade
Alto
Médio $\square$ Baixo
Entusiasmo:
$\square$ Alto
Médio
Baixo
Grau de navegação: $\square$ Só pelos links do exercício 


\section{ANEXO B}

Informações dos bancos de dados gerados 


\section{ANEXO B}

TABELA B.1 - Banco de casos clínicos estruturado para o "site" da Disciplina de Patologia Bucal: quantidade de casos e distribuição entre os grupos de patologias

\begin{tabular}{|c|c|}
\hline LESÃO & $\mathrm{N}^{\circ}$ DE CASOS \\
\hline Patologias de glândula salivar & 14 \\
\hline ADENOCARCINOMA POLIMORFO DE BAIXO GRAU & 1 \\
\hline ADENOMA PLEOMÓRFICO & 4 \\
\hline CARCINOMA ADENÓIDE CÍSTICO & 1 \\
\hline CARCINOMA EM ADENOMA PLEOMÓRFICO & 1 \\
\hline CARCINOMA MUCOEPIDERMÓIDE & 3 \\
\hline SIALADENOMA PAPILÍFERO & 1 \\
\hline CÁLCULO SALIVAR & 1 \\
\hline MUCOCELE & 1 \\
\hline SÍNDROME DE SJOGREN & 1 \\
\hline Tumores odontogênicos & 21 \\
\hline AMELOBLASTOMA & 6 \\
\hline CEMENTOBLASTOMA BENIGNO & 1 \\
\hline MIXOMA & 3 \\
\hline ODONTODISPLASIA REGIONAL & 1 \\
\hline ODONTOMA & 4 \\
\hline TUMOR DE PINDBORG & 2 \\
\hline TUMOR ODONTOGÊNICO ADENOMATÓIDE & 3 \\
\hline TUMOR ODONTOGÊNICO EPITELIAL CALCIFICANTE & 1 \\
\hline Tecidos com características de normalidade & 1 \\
\hline CAPUZ PERICORONÁRIO & 1 \\
\hline Neoplasias malignas epiteliais & 8 \\
\hline CARCINOMA DE CÉLULAS FUSIFORMES & 1 \\
\hline CARCINOMA EPIDERMÓIDE & 7 \\
\hline Cistos do sistema estomatognático & 26 \\
\hline CISTO DE ERUPÇÃO & 1 \\
\hline CISTO DE GORLIN & 1 \\
\hline CISTO DE NATUREZA ODONTOGÊNICA & 2 \\
\hline CISTO DENTÍGERO & 1 \\
\hline CISTO DERMÓIDE & 2 \\
\hline CISTO DO DUCTO NASOPALATINO & 2 \\
\hline CISTO ÓSSEO ANEURISMÁTICO & 1 \\
\hline CISTO PARADENTAL & 2 \\
\hline CISTO PERIODONTAL LATERAL & 1 \\
\hline CISTO RADICULAR & 3 \\
\hline CISTO RESIDUAL & 1 \\
\hline
\end{tabular}




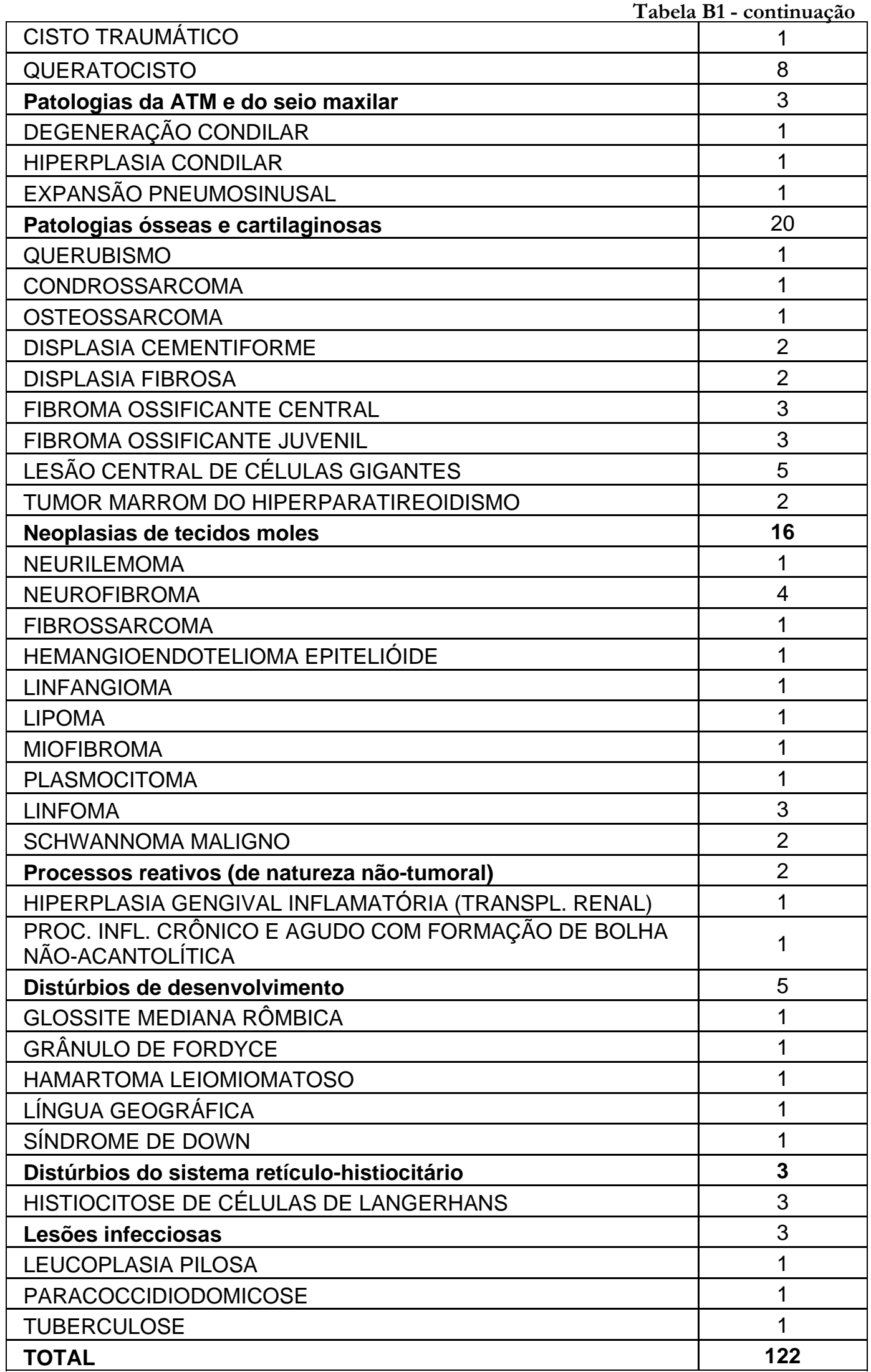


TABELA B.2 - Tema dos textos que compõem o banco de textos do "site" da Patologia Bucal

\begin{tabular}{|c|c|}
\hline \multicolumn{2}{|c|}{ DISTÚRBIOS DE DESENVOLVIMENTO } \\
\hline $\begin{array}{l}\text { Grânulos de Fordyce } \\
\text { Síndrome de Down } \\
\text { Língua geográfica }\end{array}$ & $\begin{array}{l}\text { Cisto dermóide } \\
\text { Hamartoma leiomiomatoso }\end{array}$ \\
\hline \multicolumn{2}{|c|}{ CISTO DO SISTEMA ESTOMATOGNÁTICO } \\
\hline $\begin{array}{l}\text { Comentários gerais sobre os cistos } \\
\text { Cistos odontogênicos } \\
\text { Cisto gengival do recém-nascido } \\
\text { Cisto gengival do recém-nascido } \\
\text { Cisto gengival do adulto } \\
\text { Queratocisto odontogênico } \\
\text { Cisto dentígero } \\
\text { Cisto de erupção } \\
\text { Cisto periodontal lateral } \\
\text { Cisto botrióide } \\
\text { Cisto odontogênico glandular } \\
\text { Cistos não-odontogênicos }\end{array}$ & $\begin{array}{l}\text { Cisto do ducto nasopalatino } \\
\text { Cisto nasolabial } \\
\text { Comentários gerais sobre os cistos fissurais } \\
\text { Cisto radicular } \\
\text { Cisto radicular residual } \\
\text { Cisto paradental } \\
\text { Cisto dermóide } \\
\text { Cisto epidermóide } \\
\text { Cisto linfoepitelial cervical } \\
\text { Cisto linfoepitelial oral } \\
\text { Cisto do ducto tireoglosso }\end{array}$ \\
\hline \multicolumn{2}{|c|}{ TUMORES ODONTOGÊNICOS } \\
\hline $\begin{array}{l}\text { Tumores odontogênicos benignos } \\
\text { Ameloblastoma } \\
\text { Tumor odontogênico de células claras } \\
\text { Tumor odontogênico epitelial calcificante } \\
\text { (Tumor de Pindborg) } \\
\text { Fibroma ameloblástico } \\
\text { Fibro-odontoma ameloblástico e } \\
\text { Odontoameloblastoma }\end{array}$ & $\begin{array}{l}\text { Tumor odontogênico adenomatóide } \\
\text { Odontoma } \\
\text { Odontoma composto } \\
\text { Odontoma complexo } \\
\text { Fibroma odontogênico } \\
\text { Mixoma } \\
\text { Cementoblastoma benigno } \\
\text { Tumores odontogênicos malignos }\end{array}$ \\
\hline \multicolumn{2}{|c|}{ PATOLOGIAS DAS GLÂNDULAS SALIVARES } \\
\hline $\begin{array}{l}\text { Mucocele } \\
\text { Sialolitíase ou cálculo salivar } \\
\text { Sialadenite } \\
\text { Tumores de glândulas salivares }\end{array}$ & $\begin{array}{l}\text { Adenoma pleomórfico } \\
\text { Carcinoma adenóide cístico } \\
\text { Carcinoma mucoepidermóide }\end{array}$ \\
\hline \multicolumn{2}{|c|}{ PATOLOGIAS ÓSSEAS } \\
\hline $\begin{array}{l}\text { Osteomielites } \\
\text { Osteorradionecrose } \\
\text { Alveolites (osteítes alveolares) } \\
\text { Exostose e Toro } \\
\text { Lesão central de células gigantes } \\
\text { Querubismo } \\
\text { Cisto ósseo traumático } \\
\text { Cisto ósseo aneurismático } \\
\text { Tumor marrom do hiperparatireoidismo } \\
\text { Displasia fibrosa } \\
\text { Displasia cemento-óssea (displasia } \\
\text { cementiforme) }\end{array}$ & $\begin{array}{l}\text { Osteoma } \\
\text { Osteoblastoma } \\
\text { Condroma } \\
\text { Fibroma ossificante (fibroma cemento- } \\
\text { ossificante) } \\
\text { Fibroma ossificante juvenil } \\
\text { Osteossarcoma } \\
\text { Condrossarcoma } \\
\text { Fibrossarcoma } \\
\text { Mieloma múltiplo } \\
\text { Tumores metastáticos em ossos }\end{array}$ \\
\hline
\end{tabular}


TABELA B.3 - Distribuição da natureza das imagens em relação ao item temático inserido no "site" da Disciplina de Patologia Geral

\begin{tabular}{|l|c|c|c|c|c|c|}
\hline ITEM TEMÁTICO & MICRO & MACRO & $\begin{array}{c}\text { CASO } \\
\text { CLínICO }\end{array}$ & $\begin{array}{c}\text { ESQUEMA } \\
\text { DIDÁTICO }\end{array}$ & $\begin{array}{c}\text { GIFs } \\
\text { ANIMADOS }\end{array}$ & $\begin{array}{c}\mathbf{N}^{\circ} \text { de } \\
\text { imagens }\end{array}$ \\
\hline Introdução & 0 & 0 & 0 & 2 & 0 & 2 \\
\hline História da patologia & 0 & 0 & 0 & 4 & 0 & 4 \\
\hline Conceito de saúde e doença & 0 & 0 & 2 & 0 & 0 & 2 \\
\hline Tipos de agressão & 5 & 0 & 0 & 0 & 0 & 5 \\
\hline Degenerações e infiltrações & 45 & 8 & 0 & 0 & 1 & 54 \\
\hline Calcificações patológicas & 4 & 10 & 0 & 0 & 1 & 15 \\
\hline Pigmentações patológicas & 23 & 2 & 2 & 1 & 0 & 28 \\
\hline Alterações circulatórias & 21 & 21 & 8 & 1 & 5 & 56 \\
\hline Morte celular e necrose & 6 & 2 & 1 & 0 & 0 & 9 \\
\hline Inflamação & 50 & 15 & 7 & 1 & 0 & 73 \\
\hline Reparação & 6 & 2 & 10 & 0 & 0 & 18 \\
\hline $\begin{array}{l}\text { Alterações de crescimento e } \\
\text { diferenciação }\end{array}$ & 11 & 20 & 6 & 0 & 0 & 37 \\
\hline Neoplasias & 17 & 23 & 1 & 0 & 0 & 41 \\
\hline Tecidos normais & 26 & 0 & 0 & 0 & 0 & 26 \\
\hline TOTAL & $\mathbf{2 1 4}$ & $\mathbf{1 0 3}$ & $\mathbf{3 7}$ & $\mathbf{9}$ & $\mathbf{7}$ & $\mathbf{3 7 0}$ \\
\hline
\end{tabular}

TABELA B.4 - Titulo dos textos complementares criados para compor o banco de textos do "site" da Disciplina de Patologia Geral

\section{CALCIFICAÇÕES PATOLÓGICAS}

A calcificação distrófica na ateroesclerose A calcemia

O processo normal das calcificações

\section{ALTERAÇÕES CIRCULATÓRIAS}

As pressões na hidrodinâmica vascular

O mecanismo de coagulação (hemostasia)

O "mal dos caixões" ou doença da

descompressão

Efeitos da isquemia sobre as células

\section{DEGENERAÇÕES E INFILTRAÇÕES}

A bomba de sódio e potássio e o equilíbrio hídrico celular

A química e o funcionamento da bomba de sódio e potássio

Os lipídeos e suas funções

Armazenamento de gordura nas células

O metabolismo celular das gorduras

\section{INFLAMAÇÃO}

A constituição lipídica do plasma sangüíneo

e sua relação com a parede vascular

Fatores gerais envolvidos com a

ateroesclerose

A anatomia funcional das arteríolas

O colágeno

As funções dos macrófagos e sua relação com a amiloidose

O sistema mononuclear macrofágico

A tuberculose

A histamina e os mastócitos

O sistema complemento

As reações de hipersensibilidade

As prostaglandinas e os anti-inflamatórios 
Anexo B

Tabela B4 - continuação

Os tecidos mesenquimais

O experimento de Lewis

As barreiras externas de defesa

As células inflamatórias

Os efeitos sobre a microcirculação na

inflamação

MORTE CELULAR E NECROSE

Apoptose

A influência dos lisossomos na autólise

PIGMENTAÇÃO PATOLÓGICA

Os linfonodos e sua relação com a antracose Os eritrócitos e a hemoglobina

A produção de melanina e os fatores

interferentes 


\section{ANEXO C}

Comentários dos alunos aos questionários 


\section{ANEXO C}

TABELA C.1 - Respostas ao questionário A.2 feitas pelos alunos de graduação que acessaram as páginas de Patologia Bucal pela Internet

\begin{tabular}{|lr|}
\hline O QUE VOCÊ MUDARIA NA APRESENTAÇÃO DAS PÁGINAS? & N$^{\circ}$ DE RESPOSTAS \\
\hline nada & 40 \\
resposta "não-adequada" & 4 \\
descrição histológica junto com a radiográfica para dinamização da leitura & 1 \\
cor dos links (muito escura) & 2 \\
tipo e tamanho de fonte (para melhor visualização) & 1 \\
diminuição da quantidade de frames para facilidade de impressão & 1 \\
facilitar a leitura da histopatologia (frame na parte inferior - não adequado) & 1 \\
mesmas cores em todas as páginas & 1 \\
inserção de papel de parede no fundo (ao invés de deixar branco) & 1 \\
melhor distribuição dos itens com o texto & 1 \\
matéria mais acessível (na página inicial) & 1 \\
inserção de mais exercícios & 1 \\
\hline
\end{tabular}

\section{O QUE VOCÊ MUDARIA NO SISTEMA DE NAVEGAÇÃO (LINKS)?}

nada

existência de muitas janelas

inserção de atalhos convidativos para maior liberdade de navegação

inserção de links para outras páginas (para USP, para Odonto, para os exercícios)

inserção links para os exercícios na parte teórica

dificuldade de envio pelo e-mail da sala pró-aluno

melhorar o acesso

diminuir a quantidade de links

janelas "escondidas"

necessidade de mais indicadores

link entre os casos clínicos e a parte teórica

especificidade do link para a patologia geral

abertura do Outlook quando no envio das respostas

mudança de posição dos links

inserção de abertura de novas janelas em cada link

confirmação do envio de e-mail

inserção de hiperlinks do lado esquerdo (frame estático)

inserção de link fora da USP

retirada de links no meio do texto

exercícios e teoria na mesma tela 
Tabela C1 - continuação

\begin{tabular}{|c|c|}
\hline $\begin{array}{l}\text { sistema de segurança para impedir a cola nas respostas } \\
\text { inserção de mais links que integrassem todo o conteúdo } \\
\text { criação de links diretos } \\
\text { mais conteúdo em uma mesma página } \\
\text { links mais objetivos }\end{array}$ & $\begin{array}{l}1 \\
1 \\
1 \\
1 \\
1\end{array}$ \\
\hline \multicolumn{2}{|c|}{ O QUE VOCÊ MUDARIA NO CONTEÚDO? } \\
\hline $\begin{array}{l}\text { nada } \\
\text { complementação com o conteúdo das aulas dadas } \\
\text { destaque das lesões mais importantes } \\
\text { atualização constante } \\
\text { mais informações clínicas e de tratamento } \\
\text { resumo inicial com link para texto mais completo } \\
\text { inserção de todo o conteúdo de Patologia Bucal } \\
\text { mais casos clínicos } \\
\text { não sei } \\
\text { mais patologia e explicações } \\
\text { questões de direcionamento para as provas } \\
\text { melhor comparação entre os casos clínicos } \\
\text { inserção de publicações de periódicos } \\
\text { mais informações sobre o conteúdo didático } \\
\text { aumentar o banco de dados } \\
\text { mais conteúdo } \\
\text { mais detalhes }\end{array}$ & $\begin{array}{l}37 \\
1 \\
1 \\
2 \\
1 \\
1 \\
1 \\
2 \\
1 \\
1 \\
1 \\
1 \\
1 \\
1 \\
1 \\
1 \\
1\end{array}$ \\
\hline \multicolumn{2}{|c|}{ O QUE VOCÊ MUDARIA NAS IMAGENS? } \\
\hline $\begin{array}{l}\text { nada } \\
\text { Imagens muito "pesadas" } \\
\text { mais fotos ilustrativas } \\
\text { imagens não muito nítidas } \\
\text { imagens clínicas e radiográficas maiores } \\
\text { indicação das lesões nas imagens } \\
\text { bolinhas verdes dificultam a visualização das estruturas } \\
\text { mais fotos clínicas } \\
\text { "balão" de texto ao passar o mouse nas bolinhas } \\
\text { mais imagens diferentes da mesma entidade patológica } \\
\text { links em algumas imagens não funcionam } \\
\text { alguns casos sem histopatológico } \\
\text { exames histopatológicos em maior aumento } \\
\text { algumas imagens radiográficas quase incompreensíveis } \\
\text { mais imagens histológicas } \\
\text { melhor visualização dos links para os textos } \\
\text { mais diversificações das imagens }\end{array}$ & $\begin{array}{c}37 \\
2 \\
4 \\
2 \\
1 \\
1 \\
1 \\
3 \\
1 \\
1 \\
2 \\
1 \\
1 \\
1 \\
1 \\
1 \\
1\end{array}$ \\
\hline \multicolumn{2}{|l|}{ O QUE VOCÊ MUDARIA NOS TEXTOS? } \\
\hline $\begin{array}{l}\text { nada } \\
\text { separação dos textos em tópicos (histologia, clínica etc.) } \\
\text { partes dos textos sem repetições } \\
\text { mais dados clínicos e de tratamento } \\
\text { resumo acompanhado de texto completo } \\
\text { questões com dificuldade de interpretação } \\
\text { mudaria a configuração }\end{array}$ & $\begin{array}{l}36 \\
1 \\
1 \\
1 \\
1 \\
1 \\
1\end{array}$ \\
\hline
\end{tabular}


Tabela C1 - continuação

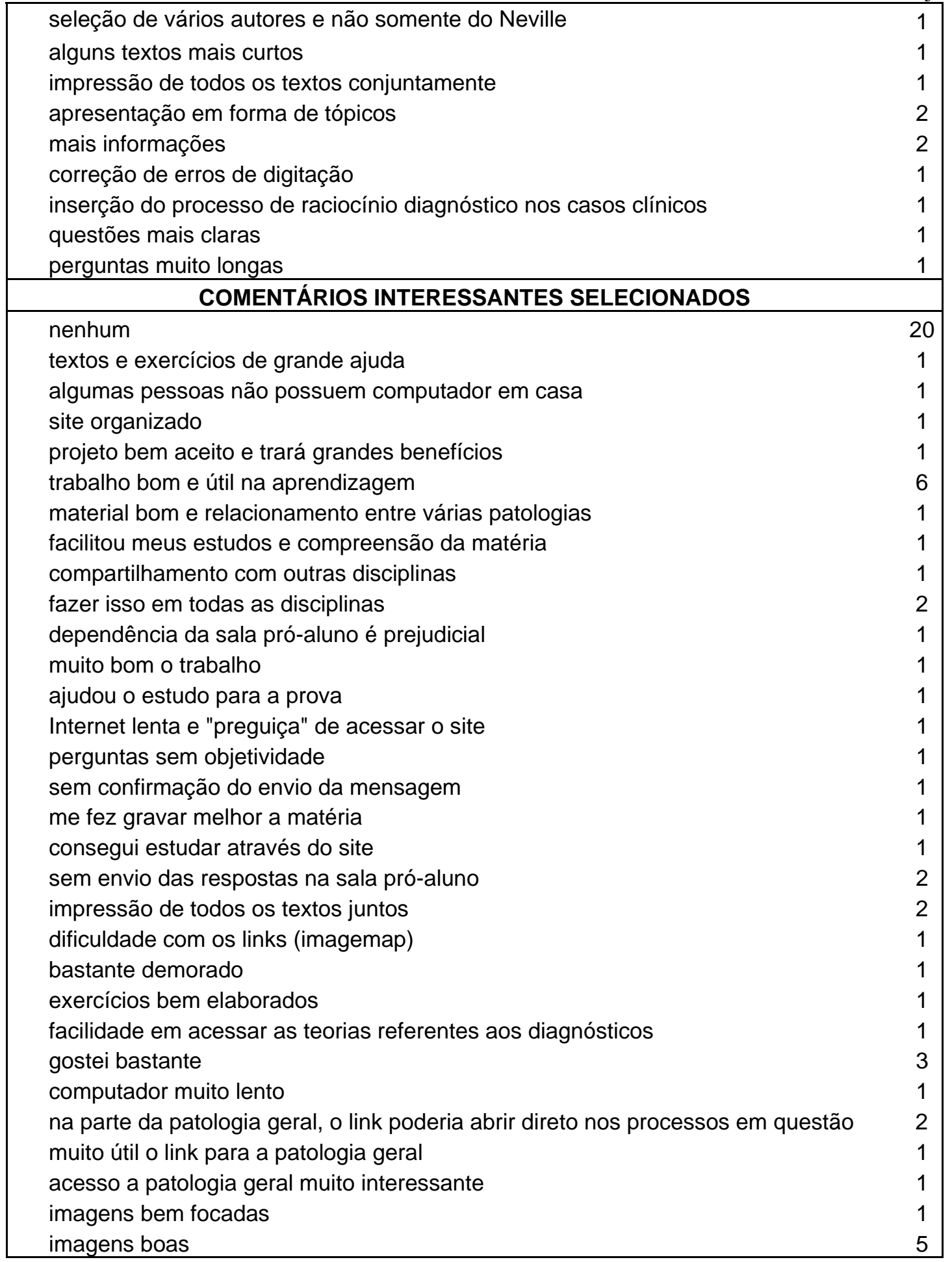


TABELA C.2 - Respostas ao questionário A.3 feitas pelos alunos de graduação que acessaram as páginas de Patologia Geral pela Internet

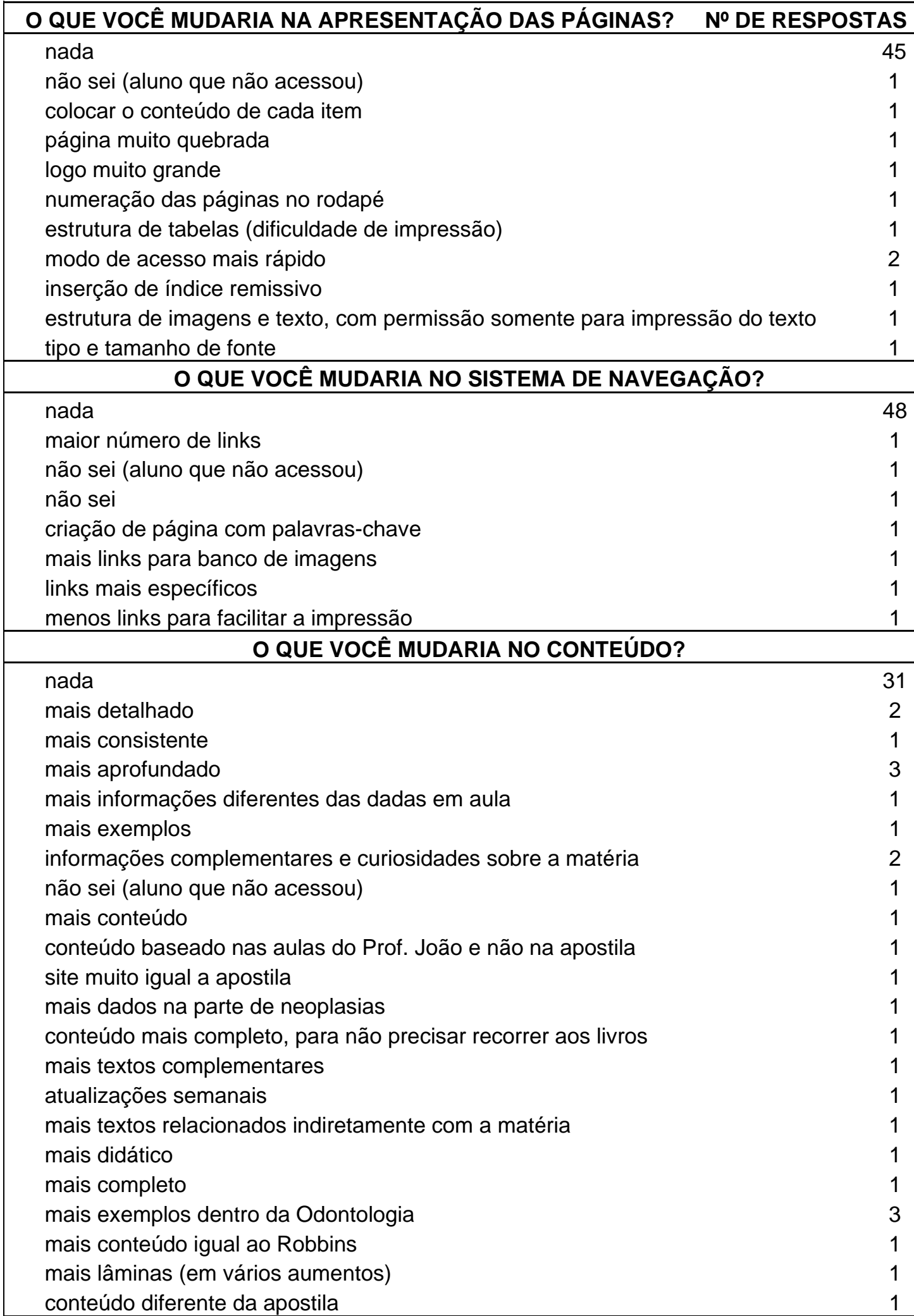




\begin{tabular}{|c|c|}
\hline \multicolumn{2}{|c|}{ O QUE VOCÊ MUDARIA NAS IMAGENS? } \\
\hline nada & 42 \\
\hline mais fotos de macroscopia e clínicas & 1 \\
\hline não sei (aluno que não acessou) & 1 \\
\hline inserção de tecidos normais ao lado dos patológicos & 1 \\
\hline mais casos clínicos de Odontologia & 2 \\
\hline mais figuras e esquemas didáticos & 1 \\
\hline mudaria o tamanho & 1 \\
\hline mais fotos & 2 \\
\hline fotos mais claras em relação ao conteúdo & 1 \\
\hline fotos maiores & 1 \\
\hline mais lâminas (em vários aumentos) & 1 \\
\hline algumas pouco nítidas & 1 \\
\hline \multicolumn{2}{|l|}{ O QUE VOCÊ MUDARIA NOS TEXTOS? } \\
\hline nada & 42 \\
\hline mais detalhado & 1 \\
\hline ser diferente do da apostila & 2 \\
\hline mais conteúdo & 1 \\
\hline não sei (aluno que não acessou) & 1 \\
\hline mais dados & 1 \\
\hline adequação ao conteúdo das provas & 1 \\
\hline mais completos & 1 \\
\hline fonte dos textos & 1 \\
\hline tiraria das tabelas & 1 \\
\hline mais didático, diferente do livro & 1 \\
\hline mais informações sobre Odontologia & 1 \\
\hline mais casos clínicos & 1 \\
\hline mais profundos & 1 \\
\hline \multicolumn{2}{|c|}{ COMENTÁRIOS INTERESSANTES SELECIONADOS } \\
\hline deveria continuar & 1 \\
\hline ajuda a compreender o conteúdo de patologia geral & 1 \\
\hline muito boa a iniciativa & 1 \\
\hline projeto excelente & 1 \\
\hline boa impressão sem ter acessado & 1 \\
\hline bem elaborado e bom para direcionar os estudos & 1 \\
\hline site ótimo & 3 \\
\hline mais exercícios (é bom para estudar) & 1 \\
\hline matéria deveria estar a disposição bem antes da prova & 3 \\
\hline questões e respostas das provas passadas & 1 \\
\hline incluir mais esquemas & 1 \\
\hline fotos muito interessantes para a observação das patologias & 1 \\
\hline ajuda muito & 1 \\
\hline links com textos complementares muito bons & 1 \\
\hline achei legal & 1 \\
\hline nada que cai na prova está lá & 1 \\
\hline bom principalmente por causa das imagens & 2 \\
\hline contribuiu para o aprendizado & 1 \\
\hline
\end{tabular}


TABELA C.3 - Respostas ao questionário A.4 feitas pelos alunos de graduação que participaram do curso de introdução à técnica cirúrgica

\begin{tabular}{|c|c|c|c|c|c|}
\hline \multicolumn{3}{|c|}{$\begin{array}{l}\text { Foi fácil realizar a técnica } \\
\text { cirúrgica e consultar o } \\
\text { "site" ao mesmo tempo? }\end{array}$} & & & \\
\hline Sim & 17 alunos & $77 \%$ & & & \\
\hline Não & 5 alunos & $23 \%$ & & & \\
\hline \multicolumn{6}{|c|}{ Por quê? } \\
\hline \multicolumn{3}{|c|}{ Sim } & $\begin{array}{l}\text { Total de } \\
\text { respostas }\end{array}$ & Não & $\begin{array}{l}\text { Total de } \\
\text { respostas }\end{array}$ \\
\hline \multicolumn{3}{|c|}{$\begin{array}{l}\text { os passos explicativos estavam } \\
\text { no "site" }\end{array}$} & 2 & $\begin{array}{l}\text { a exploração foi feita } \\
\text { instintivamente }\end{array}$ & 1 \\
\hline \multicolumn{3}{|c|}{ seqüência bem explicada } & 4 & $\begin{array}{l}\text { teve que esperar a parceira, pois } \\
\text { esta estava atrasada }\end{array}$ & 1 \\
\hline \multicolumn{3}{|c|}{ dificuldade só no início } & 1 & a ansiedade atrapalhou & 1 \\
\hline \multicolumn{3}{|c|}{ site esclareceu antes o curso } & 1 & dificuldade de interpretação do texto & 1 \\
\hline \multicolumn{3}{|c|}{ site ajuda o iniciante } & 1 & falta de habilidade & 1 \\
\hline \multicolumn{3}{|c|}{ presença de figuras ilustrativas } & 1 & $\begin{array}{l}\text { precisou de muita orientação do } \\
\text { professor }\end{array}$ & 1 \\
\hline \multicolumn{3}{|c|}{ site facilitou a técnica } & 1 & & \\
\hline \multicolumn{3}{|c|}{$\begin{array}{l}\text { sem necessidade de chamar o } \\
\text { professor }\end{array}$} & 1 & & \\
\hline \multicolumn{3}{|c|}{$\begin{array}{l}\text { velocidade de aprendizado } \\
\text { pessoal }\end{array}$} & 1 & & \\
\hline \multicolumn{3}{|c|}{$\begin{array}{l}\text { visualização do passo e depois } \\
\text { execução }\end{array}$} & 1 & & \\
\hline \multicolumn{3}{|c|}{$\begin{array}{l}\text { a linguagem WEB permite fácil } \\
\text { acesso aos tópicos }\end{array}$} & 1 & & \\
\hline \multicolumn{3}{|c|}{ a aula fica interativa } & 1 & & \\
\hline \multicolumn{3}{|c|}{$\begin{array}{l}\text { computador próximo à área de } \\
\text { atuação }\end{array}$} & 1 & & \\
\hline \multicolumn{3}{|c|}{$\begin{array}{l}\text { possibilidade de seguir passo- } \\
\text { a-passo }\end{array}$} & 1 & & \\
\hline
\end{tabular}


TABELA C.4 - Respostas ao questionário A.4 feitas pelos alunos de graduação que participaram do curso de introdução à técnica cirúrgica

\begin{tabular}{|c|c|}
\hline \multicolumn{2}{|c|}{ Momentos do curso em que os recursos foram importantes } \\
\hline Televisão & Total de respostas \\
\hline $\begin{array}{l}\text { demonstração de manobras cirúrgicas de maneira unânime para } \\
\text { alunos }\end{array}$ & a todos os 2 \\
\hline tirar dúvidas pela observação dos outros colegas & 3 \\
\hline sem comentário & 4 \\
\hline observação de determinado procedimento & 1 \\
\hline sem momento de aprendizado & 2 \\
\hline fixação das imagens & 1 \\
\hline um meio completava o outro & 1 \\
\hline importante para discutir cada etapa & 1 \\
\hline para visualização do curso ao vivo & 1 \\
\hline não acho que seja a melhor opção & 1 \\
\hline em todos os momentos & 1 \\
\hline durante as explicações do professor & 4 \\
\hline pouco utilizada & 2 \\
\hline \multicolumn{2}{|r|}{ Total de respostas } \\
\hline eliminação de dúvidas e de conceitos & 1 \\
\hline em todos os momentos, pois explicava os passos & 9 \\
\hline pela ordem seguida & 2 \\
\hline entendimento da técnica cirúrgica & 2 \\
\hline demonstração da seqüência dos passos & 2 \\
\hline verificação da técnica e da seqüência & 1 \\
\hline sem comentário & 1 \\
\hline seqüência favorável & 1 \\
\hline anestesia, corte e montagem do campo & 1 \\
\hline orientação mais prática & 1 \\
\hline \multicolumn{2}{|r|}{ Total de respostas } \\
\hline atuação individualizada & 1 \\
\hline para as dúvidas não sanadas pelo computador e pela televisão & 1 \\
\hline detalhes de correção do manuseio do instrumental & 4 \\
\hline atenção aos nossos erros & 3 \\
\hline para as dúvidas não sanadas pelo computador & 1 \\
\hline nos momentos de dificuldade & 2 \\
\hline minúcias dos passos e correção da técnica & 1 \\
\hline esperou que nós seguíssemos mais pelo computador & 1 \\
\hline em todos os momentos & 6 \\
\hline para ajudar a interpretar o texto do "site" & 1 \\
\hline $\begin{array}{l}\text { existem momentos em que só vendo ao vivo para entender (por } \\
\text { sutura) }\end{array}$ & rexemplo, na \\
\hline supervisão das manobras & 1 \\
\hline
\end{tabular}


TABELA C.5 - Respostas ao questionário A.4 feitas pelos alunos de graduação que participaram do curso de introdução à técnica cirúrgica

\begin{tabular}{|lc|}
\hline \multicolumn{2}{|c|}{ Pontos positivos e negativos do curso } \\
\hline \multicolumn{2}{|c|}{ Positivos } \\
\hline ritmo pessoal & Total de respostas \\
professor se concentra em pontos individuais & 2 \\
informação básica ao alcance de todos & 1 \\
inovação da técnica de ensino & 1 \\
organização & 1 \\
visualização (pelas imagens) & 1 \\
conhecimento do instrumental & 1 \\
o site & 4 \\
presença de poucos alunos & 1 \\
aprimoramento da técnica cirúrgica & 3 \\
didática & 6 \\
recursos tecnológicos & 2 \\
bom número de instrutores & 9 \\
os exercícios & 3 \\
visão das dificuldades na prática & 1 \\
computador junto com o professor & 2 \\
acompanhamento pela Internet, agilizando o curso & 1 \\
\hline & Negativos \\
\hline coxa da galinha não sangra muito & 1 \\
sem comentário & 1 \\
monotonia quanto ao computador & 11 \\
dificuldade quanto a seqüência & 1 \\
falta de boa visualização dos filmes & 1 \\
melhor especificação dos materiais & 1 \\
site omite minúcias da técnica & 1 \\
professor fazendo a técnica juntamente com o aluno \\
curso difícil & 1 \\
\hline
\end{tabular}


REFERÊNCIAS 


\section{REFERÊNCIAS ${ }^{1}$}

1. ANTOLÍ, V. B. A didática como espaço e área do conhecimento: fundamentação teórica e pesquisa didática. Tradução Inara Luiza Marim. In: FAZENDA, I. (Org.) Didática e interdisciplinaridade. 3. ed. Campinas : Papirus, 2000. P. 77-108.

2. ARAÚJO, N. S.; ARAÚJO, V. C. Patologia bucal. São Paulo : Artes Médicas, 1984. 239 p.

3. AZEVEDO, W. Muito além do jardim da infância: o desafio do preparo de alunos e professores "on line". Disponível em: $<$ http://www.abed.org.br/paper visem:/wilson azevedo.htm>. Acesso em: 6 set. 2000.

4. BAYLOR COLLEGE OF DENTISTRY. Center for Professional Development. Online courses. Disponível em:

$<$ http://www.tambcd.edu/DentalCE/Distance Learning/distance learning. html>. Acesso em: 22 jan. 2000.

5. BAYLOR COLLEGE OF DENTISTRY. Center for TeleHealth. Disponível em: $<$ http://www.tambcd.edu/telehealth>. Acesso em: 22 jan. 2000.

6. BIBLIOTECA VIRTUAL EM: SAÚDE. Pesquisa em base de dados.

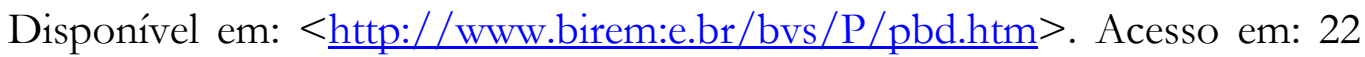
jan. 2000.

\footnotetext{
${ }^{1}$ De acordo com NBR-6023 : 2000. Abreviatura de periódicos segundo Base de Dados MEDLINE.
} 
7. BONILHA, E.; CALDAS, M. Z. Informação e comunicação no ensino superior: novas tecnologias para o ensino a distância. In: SIMPÓSIO INTERNACIONAL UNIVERSIDADE E NOVAS TECNOLOGIAS: IMPACTOS E IMPLICAÇÕES, 1999, São Paulo. Anais... São Paulo : Universidade de São Paulo, 1999. P. 63-67.

8. COLUMBIA VIDEO NETWORK. Graduate Education from Columbia

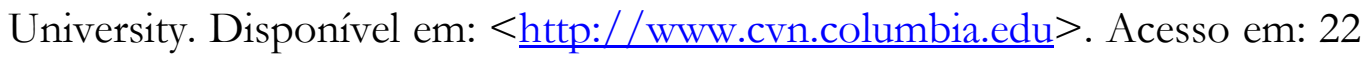
jan. 2000.

9. COOPER, K. J. Internet at school is changing work of students - and teachers. Disponível em: http://www.washingtonpost.com/wpdyn/articles/A11928-2000Sep4.html . Acesso em: 5 set. 2000.

10. CORRÊA, L. Criação e caracterização de banco de dados de diagnósticos histopatológicos em:itidos pelos Serviço de Patologia Cirúrgica da Disciplina de Patologia Bucal da FOUSP. 1998. 114fl. Dissertação (Mestrado em: Patologia Bucal) - Faculdade de Odontologia, Universidade de São Paulo, São Paulo.

11. CREIGHTON UNIVERSITY SCHOOL OF DENTISTRY. Continuing education on the Web. Disponível em: <http://cudental.creighton.edu/> Acesso em: 22 jan. 2000.

12. DOWES, P. K. The Internet for dental practitioners: current and future developments. Br Dent J, Hants, v. 185, n. 11/12, p. 569-575, Dec. 1998.

13. DUCHIER, D. State of art review on hypermidia issues and application. 1994. Disponível em:

$<\underline{\text { http:}: / / w w w . i s g . s f u . c a / ~ d u c h i e r / m i s c / h y p e r t e x t ~ r e v i e w / ~}>$. Acesso em: 23 jan. 2000.

14. FAZENDA, I. (Org.) Didática e interdisciplinaridade. 3. ed. Campinas: Papirus, 2000. P. 77-108. 
15. FERNANDES, A. P.; BASTOS, R. C.; MAGINI, R. S. Periodontology's application of multimedia. Stud Health Technol Inform, v. 51, p. 204-209, 1998.

16. FINKESLTEIN, M.; GALLAGHER, G. T.; KABANI, S. P.; O’DONOGHE, C. Oral pathology image database. Disponível em: $<$ http://www.uiowa.edu/ oprm/AtlasHome.html $>$. Acesso em: 23 jan. 2000.

17. GJERDE, C. L.; SHAPLEIGH, M. M. Health professionals' experiences with continuing and distance education. Acad Med, Washington, v. 74, n. 5. p. 568-569, May 1999.

18. GOMEZ, M. V. Avaliação formativa e continuada na educação baseada na Internet. Disponível em:

< http://www.abed.org.br/paper visem:/margarita vitoria gomez.htm> .

Acesso em: 6 set. 2000.

19. GUIDUGLI-NETO, J. Fundamentos de patologia geral. São Paulo : Artes Médicas, 1997. P.

20. HARVARD UNIVERSITY, COLUMBIA UNIVERSITY, UNIVERSITY OF PENNSYLVANIA. Yvi Dental Consortium. Disponível em:

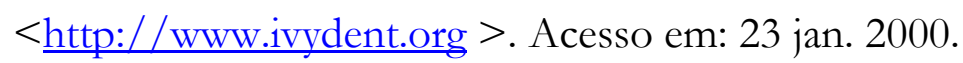

21. HEALD, B. H.; KELLY, A. Commonwealth training initiative: STEP distance learning project. Ann R Coll Surg Engl, London, v. 82, n.3, p. 100-101, Mar. 2000. Suplemento.

22. HEESTAND, D.; GARMAN, K.; FISHER, D. Faculty development through distance-learning. Acad Med, Washington, v. 71, n. 5, p. 567, May 1996.

23. HOLBOROW, D. W.; KEAN, M. R. Postgraduate diploma in clinical dentistry by distance learning. N Z Dent J, Dunedin, v. 88, n. 391, p. 13-16, Jan. 1991. 
24. HORVATH, A. O.; TELES, L. Usando a Web como ferramenta de apoio nas tarefas escolares de pesquisa. Tradução Paulo dos Santos Ferreira.

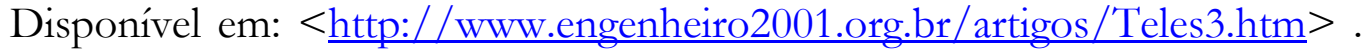
Acesso em: 6 set. 2000. Apresentado ao Journal of Interactive Learning Research.

25. INDIANA UNIVERSITY SCHOOL OF DENTISTRY. Department of Continuing Education. Disponível em:

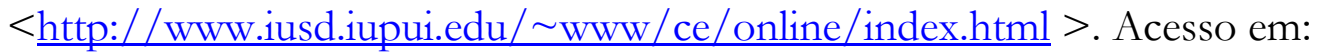
23 jan. 2000.

26. INSTITUT KAROLINSKA. Library of Institut Karolinska - Medical Images and Illustrations. Disponível em: < $\underline{\text { http://www.mic.ki.se/Medimages.html }>~}$ Acesso em: 23 jan. 2000.

27. LANDMAN, A.; YAGI, Y.; GILBERTSON, J.; DAWSON, R.; MARCHEVSKY, A.; BECICH, M. J. Prototype Web-based continuing medical education using FlashPix images. Proc AMIA Symp, p. 462-466, 2000. Disponível em:

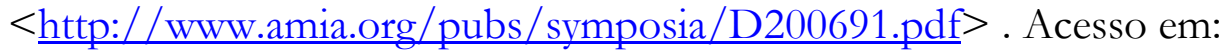
02/01/2001.

28. LANGLAIS, R. P.; MILLER, C. S. Color atlas of common oral diseases. School of Dentistry, University of Kentucky. Disponível em:

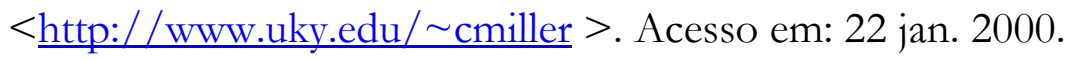

29. LEÃO, L. O labirinto da hipermídia: arquitetura e navegação no espaço. São Paulo : Iluminuras, 1999. 158 p.

30. LENOIR, Y. Didática e interdisciplinaridade: uma complem:entaridade necessária e contornável. Tradução Maria Marly de Oliveira. In: FAZENDA, I. (Org.) Didática e interdisciplinaridade. 3. ed. Campinas : Papirus, 2000. P. 45-75.

31. LÉVY, P. As tecnologias da inteligência. Tradução Carlos Irineu da Costa. Rio de Janeiro : Editora 34, 1993. 203 p. (Coleção Trans) 
32. LISTGARTEN, M. A. Histology of the Periodontium. School of Dentistry. Department of Dental Informatics. Disponível em: < http://www.tem:ple.edu/dentistry/perio/periohistology/index.html $>$. Acesso em: 22 jan. 2000.

33. LYNCH, P. J.; HORTON, S. Center for Advanced Instructional Media University of Yale. Yale Style Manual, 1997. Disponível em: <http://info.med.yale.edu/caim/manual $>$. Acesso em: 22 jan. 2000.

34. MEDICAL UNIVERSITY OF SOUTH CAROLINA. Distance education. Disponível em: < http://www.edserv.musc.edu/de//>. Acesso em: 23 jan. 2000.

35. MELLY, M. Mídia digital: imagem:, som, vídeo, internet. Curso de Produções de Mídias Interativas, Escola de Comunicações e Artes da Universidade de São Paulo. Disponível em:

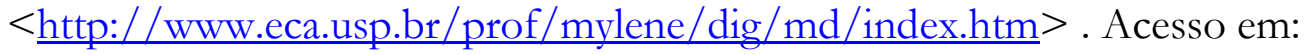
$12 / 10 / 2000$.

36. MONTEITH, B. D. Organizational considerations for an electronic curriculum. Part I: a rational nosology for concept managem:ent in dentistry. J Prosthet Dent, St. Louis, v. 79, n. 5, p. 591-595, May 1998.

37. NATIONAL LIBRARY OF MEDICINE. PubMed (Medline). Disponível em: <http://www.ncbi.nlm.nih.gov/PubMed/> . Acesso em: 22 jan. 2000.

38. NEGROPONTE, N. A vida digital. 2. ed. São Paulo : Companhia das Letras, 1995. 231 p.

39. NEVIlle, B. W.; DAMM, D. D.; ALlEN. C. M.; BOUQUOT, J. E. Patologia oral \& maxilofacial. Rio de Janeiro : Guanabara Koogan, 1998. 705 p.

40. NIELSEN, J. Projetando websites (Designing web usability). Tradução Ana Gibson. Rio de Janeiro : Campus, 2000. 416 p.

41. NISKIER, A. Educação a distância: a tecnologia da esperança. São Paulo : Loyola, 1999. 
42. NOVELLI, M. D.; ARAÚJO, N. S. Diagnóstico histopatológico a distância com auxílio de satélites artificiais de telecomunicações. Rev Odontol Metod, São Paulo, v. 2, n. 2, p. 55-61, 1981.

43. NOVELLI, M. D.; CORRÊA, L. Ensino a distância em: odontologia. Revista da ABENO, Uberlândia, 1999.

44. NOVELLI, M. D.; CORRÊA, L.; BORRA, R. C. Pato arte geral: apostila de patologia geral. São Paulo : Faculdade de Odontologia da USP, 1993.

45. NOVELLI, M. D.; SOUZA, F.; CORRÊA, L.; GAMBOA, N. (Coord.) Levantamento preliminar do conteúdo didático dos “sites" das Unidades de Ensino. São Paulo : Universidade de São Paulo, Pró-Reitorias de Graduação e Pós-Graduação 2001. 33p.

46. O'DOWD, S. Web page style guide. University of Newcastle, 1999. Disponível em: < http://www.newcastle.edu.au/guide/style guide.htm> . Acesso em: 22 jan. 2000.

47. PETERSON, M. Benefits and potential dangers of online CME. Acad Med, Washington, v. 74, n. 7, p. 750, July 1999.

48. PRESTON, J. D. Computers in dental education. J Calif Dent Assoc, Sacramento, v. 25, n. 10, p. 729-733, Oct. 1997.

49. PUTTEN Jr., M. C. Use of the Internet for educational applications in prosthodontics. J Prosthet Dent, St. Louis, v. 76, n. 2, p. 200-208, Aug. 1996.

50. RADFORD, D. R. A distance learning programme: 'managing health service’. Br Dent J, Hants, v. 23, p. 315-318, Apr. 1994.

51. REGISTRO, E. L.; SCAPIN, R. H.; MAREGA Jr., E. Uma proposta de integração da Internet ao ensino de Física do curso médio das escolas da rede pública. Disponível em:

< $\underline{\text { http://www.abed.org.br/paper visem:/rafael scapim/rafael scapim.htm> }}>$ Acesso em: 19 jan. 2001. 
52. SANDHOLTZ, J. H.; RINGSTAFF, C.; DWYER, D. C. Ensinando com tecnologia: criando salas de aula centradas nos alunos. Tradução Marcos Antônio Guirado Domingues. Porto Alegre : Artes Médicas, 1997. 196 p.

53. SANTAELLA, L; NÖTH, W. Imagem: cognição, semiótica, mídia. 2. ed. São Paulo : Iluminuras, 1999. 222 p.

54. SANTOS, E. T.; RODRIGUES, M. Educação a distância: conceitos, tecnologias, constatações, presunções e recomendações. São Paulo : EPUSP, 1999. $32 \mathrm{p}$.

55. SANTOS, N.; MELO, W.; SEGRE, L. Sistem:as de autoria para cursos a distância apoiados em: tecnologias da Internet: diretrizes para seleção.

Disponível em:

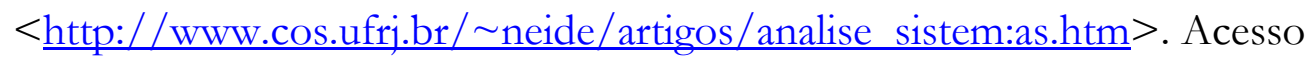
em: 6 set. 2000 .

56. SCHELEYER, T. Assessing outcomes of an academ:ica computing initiative. J Dent Educ, Washington, v. 62, n. 6, p. 432-440, June 1998.

57. SCHELEYER, T. K. How should dental informatics evolve? J Dent Educ, Washington ,v. 60, n. 3, p. 291-295, Mar. 1996.

58. SCHELEYER, T.; SPALLEK, H.; TORRES-URQUIDY, M. H. A profile of current Internet users in dentistry. J Am Dent Assoc, Chicago, v. 129, n. 12, p. 1748-1753, Dec. 1998.

59. SCHULTZ, S.; KLAR, R.; AUHUBER, T.; SCHRADER, U.; KOOP, A.; KREUTZ, R.; OPPERMAN, R.; SIMM, H. Quality criteria for electronic publications in Medicine. Disponível em: < $\underline{\text { http://www.imbi.uni- }}$ freiburg.de/medinf/gmdsqc/e.htm>. Acesso em: 28 nov. 2000.

60. SIMPSON, A.; WEIST, A.; READING, N. G.; ROBERTS, C. M. A pilot internet teaching project to support specialist medical training. Hosp Med, London, v. 60, n. 12, p. 904-907, Dec. 1999. 
61. SMITH, T. A.; LYON, E.; HARDISON, D.; BOGIA, B. Using a Delphi Technique in a needs assessment for an innovative approach to advanced general dentistry education. J Dent Educ, Washington, v. 59, n. 3, p. 442447, 1995.

62. SMITH, T. A; RAYBOULD, T. P.; HARDISON, J. D. A distance learning program in advanced general dentistry. J Dent Educ, Washington, v. 62, n. 12, p. 975-984, Dec. 1998.

63. STANTON, F.; GRANT, J. Approaches to experiential learning, course delivery and validation in medicine. A background document. Med Educ, Oxford, v. 33, n. 4, p. 282-297, Apr. 1999.

64. TEMPLE UNIVERSITY. School of Dentistry. Department of Dental Informatics. Computer applications in Dentistry. Disponível em:

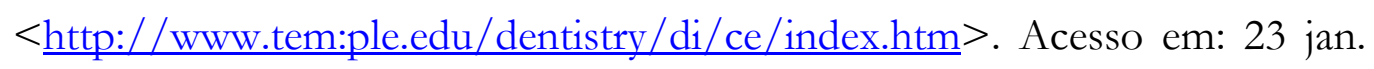
2000 .

65. UNIVERSIDADE DE SÃO PAULO. Faculdade de Odontologia de Ribeirão Preto. Departamento de Morfologia. Disponível em: < http://www.forp.usp.br/mef>. Acesso em: 23 jan. 2000.

66. UNIVERSITY OF CONNECTICUT. School of Dental Medicine. Disponível em: < http://SDM.UCHC.edu/ProjectD/Roadmap.html $>$. Acesso em: 22 jan. 2000.

67. UNIVERSITY OF COPENHAGEN, UNIVERSITY OF LUND, UNIVERSITY OF SHEFFIELD. School of Dentistry. Lucas Project.

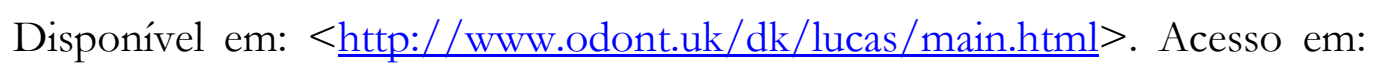
22 jan. 2000.

68. UNIVERSITY OF GLASGOW. School of Dentistry. Disponível em:

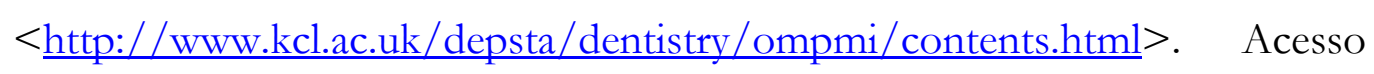
em: 22 jan. 2000. 
69. UNIVERSITY OF IDAHO. College of Engineering. Distance education at a glance. Guide \# 1. October, 1995. Engineering Outreach. Disponível em: <http://www.uidaho.edu/evo/dist1.html >. Acesso em: 22 jan. 2000.

70. UNIVERSITY OF ILLINOIS AT CHICAGO. College of Dentistry. Online course material. Disponível em:

<http://dentistry.uic.edu/courses/index.html>. Acesso em: 22 jan. 2000.

71. UNIVERSITY OF NAGASAKI. School of Dentistry. Disponível em: < http://w3.dh.nagasaki-u.ac.jp/tf/disease.html >. Acesso em: 23 jan. 2000.

72. UNIVERSITY OF NANCY. School of Dentistry. Disponível em:

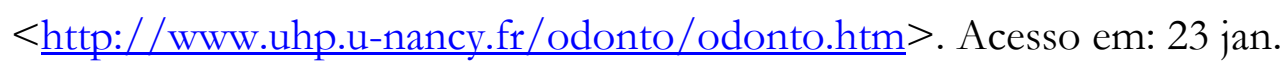
2000.

73. UNIVERSITY OF NEWCASTLE. School of Dentistry. Dental Innovative Educational Technology. Disponível em: $<\underline{\text { http://cal- }}$ serv.dental.gla.ac.uk/diet/index.htm>. Acesso em: 22 jan. 2000.

74. UNIVERSITY OF NEWCASTLE. School of Dentistry. Disponível em: < http://www.ncl.ac.uk/ nresdent/>. Acesso em: 23 jan. 2000.

75. UNIVERSITY OF NORTH CAROLINA AT CHAPEL HILL. School of Dentistry. Disponível em:

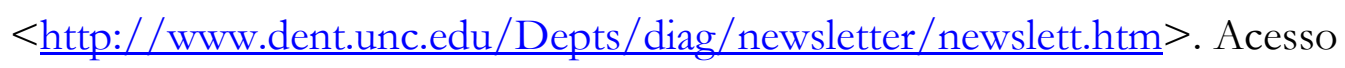
em: 23 jan. 2000.

76. UNIVERSITY OF PENNSYLVANIA. School of Dentistry. Pathology 615.

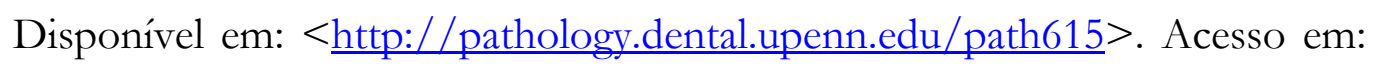
23 jan. 2000.

77. UNIVERSITY OF WESTERN ONTARIO. School of Dentistry. Disponível em: <http://www.canweb.ca/drgalil/>. Acesso em: 22 jan. 2000.

78. VIEIRA, F. M. S. A educação na era da informação e comunicação. Disponível em: < http://www.connect.com.br/ntem:g7/>. Acesso em: 10 dez. 2000. 


\section{SUMMARY}

\section{CHANGE OF UNDERGRADUATION TEACHING MODEL APPLIED TO PATHOLOGY IN DENTISTRY: PROPOSE OF DISTANCE TEACHING- LEARNING USING THE INTERNET}

Distance learning is a new modality of teaching-learning model, which involves modern information technologies, such as the Internet. In dental and medical areas, distance learning has been used especially to continuing education and graduation courses. The results of costs/benefits and efficiency produced by these courses are not established yet. In the undergraduation courses, scientific papers related to distance learning and Internet are rare. The purpose of this study was to analyse the effect of a new teaching-learning model upon students of day and night courses, during the year of 2000 (2 $2^{\text {nd }}$ semester) using General Pathology and Oral Pathology Internet sites. In this analysis the interdisciplinary potential of hypertext technology was focused, as well as the establishment of a protocol of online didactic material production. Digital databases were performed, which were used to create three Internet sites: one of Oral Pathology and two of General Pathology. These sites were applied to undergraduate students enrolled at Oral Pathology and General Pathology disciplines of the 
Dental School of the University of Sao Paulo, as well as to the dental students of whole Brazil enrolled at introduction to surgical technique course, ministered during the XXV Dental Brazilian University Meeting. The results of this application indicated that the students are prepared to use the Internet as a learning tool. They approved this experiment, which involved presence and nonpresence teaching models. Nevertheless, the students showed difficulties in manipulating the hypertext documents, what indicates that they are in transition between linear and non-linear learning resources. Fails in the technological infrastructure and in the curricular skills were also detected. It was concluded that the change of dental learning-teaching model is viable, considering the performance of the dental students. However, modifications in the institution and the teacher's behavior are necessary, especially regarding the technological infrastructure, curricular skills and pedagogical models dedicated to interdisciplinarity. 


\section{AUTORIZAÇÃo}

Autorizo a reprodução e/ou divulgação total ou parcial da presente obra impressa, por qualquer meio convencional ou eletrônico, desde que citada a fonte e comunicada, ao autor, a referência em que consta a citação.

\section{LUCIANA CORRÊA}

Assinatura

Instituição: Faculdade de Odontologia da USP

Local e Data: São Paulo, ____/2001.

Endereço: Rua Dr. Gabriel dos Santos, 600 apto. 82

E-mail: e-lu@fo.usp.br 